\title{
The impact of COVID-19 employment shocks on suicide and safety net use: An early-stage investigation*
}

\author{
Michihito Ando ${ }^{\dagger}$ Masato Furuichi ${ }^{\ddagger}$
}

November 24, 2021

\begin{abstract}
This paper examines whether the COVID-19-induced employment shocks are associated with increases in suicides and safety net use in the second and third quarters of 2020. We exploit plausibly exogenous regional variation in the magnitude of the employment shocks in Japan and adopt a difference-indifferences research design to examine and control for possible confounders. Our preferred point estimates suggest that a one-percentage-point increase in the unemployment rate in the second quarter of 2020 is associated with, approximately, an additional 0.52 suicides, 28 unemployment benefit recipients, 88 recipients of a temporary loan program, and 10 recipients of public assistance per 100,000 population per month. A simple calculation based on these estimates suggests that if a region experienced a one-percentage-point increase in the unemployment rate caused by the COVID-19 crisis in the second quarter of 2020, which is roughly equivalent to the third-highest regional employment shock, this would be associated with $37.4 \%, 60.5 \%$, and $26.5 \%$ increases in the total, female, and male suicide rates respectively in July 2020 compared with July 2019. Our baseline findings are robust to several different model specifications, although we do not assert that our research design perfectly solves the problem of estimation bias.
\end{abstract}

JEL classification: H53, I18, I38, J21, R23, R29

Keywords: COVID-19, regional employment shocks, unemployment rate, suicide, social safety net

*This paper has previously been circulated under the title "The impact of COVID-19 employment shocks on suicide and poverty alleviation programs: An early-stage investigation". This work was supported by JSPS KAKENHI Grant Number JP20K01733. All the data and graphs presented in the paper will be available at https://github.com/michihito-ando, where the estimation results and graphs are presented in more interactive forms. We thank seminar participants for useful comments and Masaya Waki for excellent research assistance. We are also grateful to

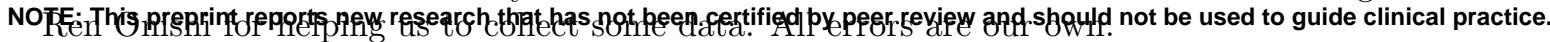

${ }^{\dagger}$ Rikkyo University, Department of Economics. Email: michihito.ando@rikkyo.ac.jp

$\ddagger$ Teikyo University, Department of Economics. Email: masato@main.teikyo-u.ac.jp 
medRxiv preprint doi: https://doi.org/10.1101/2020.11.16.20232850; this version posted November 24, 2021. The copyright holder for this

\section{Introduction}

The COVID-19 pandemic has caused serious infections and deaths around the world, and it is becoming clearer that its economic and social consequences are also tremendous. The COVID-19 pandemic and subsequent social-distancing policies have caused a sharp contraction of economic and social activities. National governments around the world have been trying to mitigate socio-economic damages by introducing new emergency cash benefits and expanding existing safety net programs. There are daily news reports of job loss, poverty, mental disorders, and even suicides that have been directly or indirectly induced by the COVID-19 crisis. Numerous social-science studies of the impact of the COVID-19 crisis have also been published on a daily basis.

However, it is still not well understood how the COVID-19 economic shocks, such as a sharp increase in unemployment, have affected society. Previous social science studies have tended to focus on how the COVID-19 crisis as a whole, including social distancing policies, has affected economic and social outcomes, but fewer studies have directly examined the effects of COVID-19-induced employment shocks on social outcomes such as mental and financial distress.

In this paper, we provide an early-stage analysis on how the COVID-19-induced employment shocks are associated with suicide and financial distress during and after the first wave of COVID-19 in Japan. We exploit an increase in the regional unemployment rate as an indicator of the economic shocks because a deteriorating employment environment can directly and indirectly harm the well-being of workers and their families. We focus on suicide and safety net use as social outcomes because the former can be interpreted as a devastating consequence of deteriorated wellbeing and the latter are administrative indices that reflect the number of people or households that suffer from distressed living and financial conditions.

As a research design, we exploit a considerable regional variation in the magnitude of the COVID-19-induced increase in unemployment: regional (i.e., prefecturelevel) employment shocks were larger in metropolitan areas and regions with popular sightseeing spots where a greater portion of employed people work in the service industry. We then adopt a difference-in-differences (DID) research design with an event-study specification and examine how the regional employment shocks caused by COVID-19 are associated with the regional trends of suicide rates and safety net participation before and during the crisis. As for safety net programs, we examine five programs in Japan's three-tier safety net system addressing unemployment and poverty: unemployment benefits (first tier), two temporary loans and a temporary housing benefit (second tier), and a public assistance program (third tier).

We do not argue that our research design perfectly solves the problem of estimation bias. We therefore also implement a counterpart DID estimation that incorporates pre-determined covariates in order to control for possible confounding 
medRxiv preprint doi: https://doi.org/10.1101/2020.11.16.20232850; this version posted November 24, 2021. The copyright holder for this

COVID-19 impacts through other pathways. In addition, we also implement several robustness checks using different model specifications. We then carefully interpret our estimation results as correlations between the COVID-19-induced employment shock and the outcomes of interest, which are expected to reflect causal relations from the former to the latter.

Our preferred point estimate suggests that a one-percentage-point increase in the unemployment rate in the second quarter (i.e., April to June) of 2020 is associated with an additional 0.522 suicides per 100,000 population in the subsequent month, July 2020. This effect size is not negligible given that the suicide rate was 1.395 in July 2019 (based on the estimated days of death), implying a 37.4\% increase in the suicide rate. The counterpart estimates and the rates of increase for female and male suicide rates are $0.518(60.5 \%)$ and $0.521(26.5 \%)$ respectively.

The counterpart point estimates for the safety net programs show that the same one-percentage-point increase in the regional unemployment rate is associated with an additional 27.9 unemployment benefit recipients, an additional 87.8 temporary loan program recipients, and an additional 9.7 public assistance recipients per 100,000 population in July 2020. These results imply that all three tiers of safety net programs responded to COVID-19-induced employment shocks and the second-tier safety net of temporary loans in particular played an important role in this period.

The contributions of our paper are three-fold. First, we provide early-stage plausible evidence of association between the COVID-19-induced employment shocks and mental and financial distress such as suicide and safety net use. This association has rarely been studied so far, although several epidemiological studies investigate suicide under the COVID-19 pandemic $[1,2,3,4,5,6,7,8,9,10]$ and several economic studies examine socio-economic outcomes including unemployment and safety net use under the COVID-19 economic crisis $[11,12,13,14,15]$. There is also research that examines relationship between unemployment and safety net use under the COVID-19 crisis based on a social survey [16] and some studies also point out that the rise in unemployment caused by the COVID-19 pandemic is expected to lead to an increase in the suicide rate $[17,18] .{ }^{1}$ But few studies directly investigate how COVID-19-induced unemployment is associated with suicide and safety net utilization using administrative data.

Second, from a more general viewpoint, our study also contributes to the literature on the impact of unemployment on suicide. The effect of unemployment on suicide has been extensively studied in social sciences $[20,21,22,23,24,25,26$, 27, 28, 29, 30] and public health (see a systematic review [31]) and many studies have shown that increases in unemployment are associated with a rise in the suicide rate. For example, Ruhm [20] shows that a one-percentage-point increase in the

\footnotetext{
${ }^{1}$ Another study examines the possible long-run impacts of the economic consequences of COVID-19 on various socio-economic outcomes from a historical perspective [19].
} 
medRxiv preprint doi: https://doi.org/10.1101/2020.11.16.20232850; this version posted November 24, 2021. The copyright holder for this

state unemployment rate was associated with an approximate $1.3 \%$ increase in the suicide rate in the US and some studies reviewed in Franquiho et al. [31] provide counterpart estimates with a range of $0.79-4.5 \%$ increases. These estimates in the previous studies are much lower than our counterpart estimated effect size of $37.4 \%$, but one caveat is that our estimate represents the largest monthly, not yearly as in most studies, effect in the second and third quarters of 2020.

Third, our study is also related to the literature on the impact of unemployment on poverty and safety net use. Some studies examine the impact of unemploymentrate fluctuation on use of safety net programs such as unemployment insurance benefits and means-tested programs before the COVID-19 crisis [32, 33, 34]. Our findings add new evidence to the literature by estimating and comparing the impact of unemployment on the use of multi-tier safety net programs.

The rest of the paper is organized as follows. Section 2 describes background information about the first wave of COVID-19 in Japan in 2020, provides the definitions and the descriptive statistics of our dataset, and presents some descriptive evidence regarding our research topic. Section 3 describes our research design and empirical model. In Section 4 we present baseline estimation results and in Section 5 we also provide the results of robustness checks and alternative estimations with a different employment-shock variable. Section 6 concludes.

\section{Background and data}

This section provides some background about the first wave of COVID-19 in Japan and the data that we use for our empirical analysis. First, we briefly describe the COVID-19 crisis in Japan, particularly focusing on the period of the first wave between April and June 2020. Second, we explain the definitions and institutional backgrounds of outcome and treatment variables. Third, we provide data sources and descriptive statistics of key variables. Fourth, we show descriptive evidence regarding the association between COVID-19-induced employment shocks and the outcomes of interest using time-series graphs, a bar plot, and scatter plots.

\subsection{The first wave of COVID-19}

During and after the first wave of COVID-19 in Japan, which started in March 2020 and ended in June 2020 (Figure A.1 in Appendix A), Japan suffered from economic and social difficulties despite its relative success in mitigating COVID-19 infection spread. Unlike many Western countries where COVID-19 lockdowns were legally enforced, in Japan, social distancing interventions including Japan's first "COVID19 state of emergency" (hereafter the first state of emergency) were based on noncompulsory requests made by the central and local governments. However, several mobility indices show that mobility significantly decreased during the period of the 
medRxiv preprint doi: https://doi.org/10.1101/2020.11.16.20232850; this version posted November 24,2021 . The copyright holder for this preprint (which was not certified by peer review) is the author/funder, who has granted medRxiv a license to display the preprint in

It is made available under a CC-BY-NC-ND 4.0 International license .

first state of emergency (see, for example, Figure A.2 in Appendix A). Subsequent reduction in social and economic activities under the first wave had considerable impact on employment.

At the same time, the period from the outset of the COVID-19 crisis in February 2020 to the end of the first wave of COVID-19 in June 2020 was an important stage in Japan's COVID-19 policy formation during which basic epidemiological, social and fiscal schemes against COVID-19 were constructed (Figure A.1). The first COVID19 state of emergency was declared on 7th April in seven prefectures, including the Tokyo and Osaka metropolitan areas. On April 16, the State of Emergency Declaration was extended to cover the entire country. Then, as the infection level steadily dropped, the government gradually lifted the state of emergency in multiple phases starting in the middle of May.

During this period, the first and second supplementary budgets as emergent COVID-19 fiscal measures passed on 30th April and 12th June respectively. The total amount of these two supplementary budgets was 57,602 billion JPY (around 520 billion USD given that 1 USD $=110 \mathrm{JPY}$ ) and around $10.7 \%$ of GDP in 2020 [35]. The largest component of the first supplementary budget was a lump-sum transfer program consisting of a one-time transfer of 100,000JPY (around 910USD) to all individuals living in Japan. There were also several other transfer programs that were intended to support firms and their employees under the COVID-19 crisis, but financial supports for people who lost their jobs or incomes due to COVID-19 during this period were mostly realized by the existing three tiers of safety net programs that we explain in the next subsection. ${ }^{2}$

\subsection{Outcomes of interest}

Our outcomes of interest are the suicide rate by gender and the utilization of the three tiers of safety net programs before and after the first wave of COVID-19 in Japan. They consist of the monthly panel data of 47 prefectures $^{3}$ from January 2018 to September 2020 (33 months). The full sample size is 1551, although some safety-net outcome variables lack data in some months. We use the administrative aggregated statistics provided by the central government for all of the outcome variables. See also Table A.1 in Appendix A for further details about the three tiers of safety net programs such as eligibility, amount per recipient, and duration.

Suicide rate Our primary outcome of interest is the suicide rate, which is the number of suicides per 100,000 population. We investigate the monthly panel data of

\footnotetext{
${ }^{2}$ See Ando et al. [35] for more detailed background information and the contents of Japan's fiscal responses against the first wave of COVID-19 and the subsequent first COVID-19 state of emergency.

${ }^{3} 47$ prefectures, such as Tokyo, Kyoto, and Hokkaido, are second-tier local governments and third-tier local governments consist of 1,718 municipalities.
} 
medRxiv preprint doi: https://doi.org/10.1101/2020.11.16.20232850; this version posted November 24,2021 . The copyright holder for this preprint (which was not certified by peer review) is the author/funder, who has granted medRxiv a license to display the preprint in

It is made available under a CC-BY-NC-ND 4.0 International license .

three suicide-rate variables: total suicide rate, female suicide rate, and male suicide rate. The number of suicides is aggregated based on the dates and places of suicide. Suicide statistics are originally provided as police statistics and aggregated and arranged by the Ministry of Health, Labour, and Welfare (MHLW) as the Statistics of Suicide (Jisatsu no Tokei).

Unemployment benefits (first-tier safety net) The first outcome of a safety net program examined is the number of unemployment benefit recipients per 100,000 population under the unemployment insurance program. ${ }^{4}$ Unemployment insurance is unarguably the first-tier safety net program for the unemployed in most developed countries, but there are some caveats about the Japanese unemployment insurance system. First, the coverage rate of the unemployment benefits among unemployed was less than $30 \%$ in Japan in the early 2010s and it is lower than other developed countries even after taking into account institutional differences [36]. ${ }^{5}$ Second, the COVID-19-induced employment shocks are more concentrated on part-time or contingent workers [15] and contingent workers are often ineligible for unemployment benefits. As a result unemployment insurance may not have worked well as a social safety net against the COVID-19 employment shocks [37].

In addition, instead of original monthly outcomes, we use the year-on-year monthly outcomes in which an outcome value at month $t-12$ is subtracted from an outcome value at month $t$. This procedure of year-on-year difference is meant to capture a monthly change in the number of beneficiaries from one year earlier rather than a monthly total number, which is the sum of existing and new beneficiaries. This procedure also eliminates prefecture-specific monthly fixed effects.

Temporary loan programs (second-tier safety net) The second and third outcomes of safety net programs are the numbers of accepted applications per 100,000 population for two types of interest-free and guarantor-free temporary loan programs: Emergency Small Amount Funds for those who urgently need cash (up to 200,000 JYP or about 1,800 USD) and General Support Funds for those who need cash for a certain period (up to 150,000-200,000 JYP or about 1,400-1,800 USD per month). They are both existing means-tested temporary loan programs which

\footnotetext{
${ }^{4}$ As unemployment benefit recipients we count the number of the people who received the "basic benefit" that is the main component of the Japanese unemployment insurance system.

${ }^{5} \mathrm{In}$ addition, the pseudo-coverage rate of unemployment benefits provided by OECD was $22.4 \%$ in Japan in 2018, which is also among the lowest in OECD countries. The numerator of this rate is the number of beneficiaries of unemployment insurance and of non-contributory benefits for job seekers and the denominator is the number of unemployed individuals (over 15 years old) according to the ILO definition. See OECD website for Social Benefit Recipients (SOCR) annual data (https://www.oecd.org/social/ recipients-socr-by-country.htm, last accessed on 17th October 2021.) for further details.
} 
medRxiv preprint doi: https://doi.org/10.1101/2020.11.16.20232850; this version posted November 24,2021 . The copyright holder for this preprint (which was not certified by peer review) is the author/funder, who has granted medRxiv a license to display the preprint in

It is made available under a CC-BY-NC-ND 4.0 International license .

can be utilized as second-tier safety net programs before applying for public assistance. They were rarely used before the COVID-19 crisis (see Figure 1). However, their requirements have also been relaxed since March 2020 and the number of loan recipients has increased dramatically.

Housing Security Benefit (second-tier safety net) The fourth safety net program outcome is the number of newly accepted applications per 100,000 population for the Housing Security Benefit, which is an existing scheme of short-term (i.e., three to nine months in 2020) housing allowance, which is also a second-tier safety net program in Japan. This benefit scheme, originally intended only for those who have lost their jobs, was rarely used before the COVID crisis as shown in Figure 1. But since April 2020, its eligibility has been extended to those who have not lost their jobs but have nevertheless experienced a large income reduction, resulting in a considerable increase in the number of households receiving these benefits. This housing allowance scheme covers the entire rent up to a certain upper limit.

Public assistance (third-tier safety net) The fifth and sixth variables of safety net programs are the per-capita numbers of public assistance recipients and recipient households. The public assistance program in Japan, the third-tier safety net, is considered to be the "final safety net" or "last resort," and the prerequisites for application are in general strict, such as having no savings and no assets. We can use only total recipient and total recipient household numbers for monthly prefecturelevel data.

As we use year-on-year monthly outcomes of unemployment benefit recipients, we also use year-on-year monthly public assistance outcomes. This procedure is meant to capture a monthly change in the number of beneficiaries from one year earlier and to eliminate prefecture-specific monthly fixed effects.

\subsection{Treatment variables}

For a treatment variable, we use a continuous variable that reflects a sudden and plausibly exogenous regional variation in the COVID-19-induced employment shock. We adopt the unemployment rate as a baseline employment indicator because it is most commonly used in the literature. We also use a supplementary employment indicator based on the statistics of registered full-time-job seekers for a robustness check.

Baseline employment shocks As a baseline treatment variable, we use a continuous variable that reflects a sudden and plausibly exogenous regional variation in the COVID-19-induced employment shock, using quarterly unemployment statistics. 
medRxiv preprint doi: https://doi.org/10.1101/2020.11.16.20232850; this version posted November 24, 2021. The copyright holder for this preprint (which was not certified by peer review) is the author/funder, who has granted medRxiv a license to display the preprint in It is made available under a CC-BY-NC-ND 4.0 International license .

We define the COVID-19-induced employment shock as the following de-trended increase in the regional unemployment rate in the second quarter (i.e., April to June) of 2020 :

$$
\text { EmpShock }_{i}=\left[\left(X_{i, 2020 Q 2}-X_{i, 2019 Q 2}\right)-\left(X_{i, 2019 Q 4}-X_{i, 2018 Q 4}\right)\right]
$$

where $i$ indicates prefecture, $X$ is the unemployment rate, and $Q 2$ and $Q 4$ are the second and fourth quarters respectively. The first term in equation (1) is a yearon-year difference in the unemployment rate in the second quarter of 2020, which consists of a COVID-19-induced employment shock and a prefecture-specific year trend. The second term is a corresponding year-on-year difference in the fourth quarter of 2019, which should reflect a prefecture-specific year trend just before the COVID-19 crisis. Assuming that the prefecture-specific year trends are similar just before and after the COVID-19 crisis, the difference between these two terms is thus expected to capture only the COVID-19-induced employment shock.

Note that what we use for $X$ is the prefecture-level estimates of the unemployment rate provided in the Labour Force Survey. The prefecture-level estimates are estimated by the Statistics Bureau. The Bureau states that some imprecision is expected in these estimates, but we treat the estimated values as true values and do not consider their statistical uncertainty in our statistical analysis due to data limitations.

Alternative "full-time" employment shocks As an additional analysis, we construct another employment-shock treatment variable based on a more narrowly defined employment indicator. That is, for the numerator of the regional unemployment rate $X_{i t}$ in equation (1) we use the number of the unemployed people who are registered as full-time-job seekers at public employment security offices, instead of the total number of the unemployed. We call this variable the variable of a "fulltime" employment shock and describe estimation results based on this alternative treatment variable in the section on robustness checks.

Because registered full-time-job seekers are often, though not always, the breadwinners of households and are eligible for unemployment benefits, this alternative "full-time" employment-shock variable may reflect a specific part of the entire employment shock in a prefecture. ${ }^{6}$ That is, this "full-time" employment-shock variable may strongly reflects the COVID-19 shocks for full-time workers who are entitled to receive unemployment benefits. Note also that although $X_{i t}$ is quarterly in the baseline definition (1), we use the number of the registered full-time-job seekers in June for the second quarter and December for the fourth quarter, because the yearon-year total numbers of registered job seekers temporarily dropped in April and

\footnotetext{
${ }^{6}$ To receive unemployment benefits, an unemployed person needs to be registered at public employment security offices.
} 
medRxiv preprint doi: https://doi.org/10.1101/2020.11.16.20232850; this version posted November 24,2021 . The copyright holder for this preprint (which was not certified by peer review) is the author/funder, who has granted medRxiv a license to display the preprint in

It is made available under a CC-BY-NC-ND 4.0 International license .

May 2020, probably due to the COVID-19 state of emergency in these months.

\subsection{Summary statistics}

Table 1 shows the summary statistics of our dataset. Because the employment-shock variable defined in equation (1) and covariates are time-invariant and cross-sectional variables, we have 47 observations. The outcome variables such as suicide rates, unemployment benefit recipients, and public assistance recipients include 33-months of data (from January 2018 to September 2020) while the variables of the secondtier safety net programs such as Emergency Small Amount Funds, General Support Funds, and Housing Security Benefit are more restricted due to data limitations. ${ }^{7}$

Table A.2 in Appendix A presents definitions and data sources of all the variables used for analyses. All the data except for the second-tier safety net programs (Emergency Small Amount Funds, General Support Funds, and Housing Security Benefits) are obtained from the websites of the Ministry of Health, Labour, and Welfare (MHLW) and Statistics Bureau of Japan. When it comes to the data of the second-tier safety net programs, we use the datasets that are directly provided by MHLW.

\subsection{Descriptive evidence}

Before moving on to the econometric analysis, we provide some descriptive evidence that suggests an association between the increase in the unemployment rate and the increases in suicide and safety net use in the midst of the COVID-19 crisis. We firstly provide the nation-level time-series graphs of employment status and outcome variables before and after the onset of the first wave of COVID-19. We then present the scatter plots of suicide rates versus our baseline treatment variable (the COVID19-induced employment shock measured by the unemployment rate).

Figure 1 describes how the status of employment, suicide, and safety-net provisions in Japan evolved before, during, and after the first wave of COVID-19 in 2020. These nation-level statistics are constructed based on four major employment

\footnotetext{
${ }^{7}$ For Emergency Small Amount Funds and General Support Funds, we use the monthly data between January 2019 and September 2020, but due to limited data availability we do not have the data for February and March 2020; statistics for these two months were missing from the original data provided by the government. In addition, the monthlylevel data aggregation from April to July 2020 is slightly irregular, although it should not cause serious estimation bias. More concretely, the number of loan decisions between April and July 2020 in the statistics provided by the central government is aggregated as follows: April data is based on the numbers from 25th March to 2nd May, May data is from 3rd May to 30th May, June data is from 31st May to 27th June, July data is from 28th June to 1st August, August data is from 2nd August to 29th August, and September data is from 30th August to 3rd October. For Housing Security Benefit, we can use only January, February, and March 2019 in the pre-COVID-19 period because of the limited data availability.
} 
Table 1: Summary Statistics

\begin{tabular}{lrrrrr}
\hline & $\mathrm{N}$ & Mean & Std.Dev. & Min & Max \\
\hline Treatment & & & & & \\
Employment shock (baseline) & 47 & 0.25 & 0.42 & -0.77 & 1.23 \\
Employment shock (full-time) & 47 & 0.08 & 0.08 & -0.14 & 0.22 \\
Outcome & & & & & \\
Suicide rate (total) & 1551 & 1.36 & 0.38 & 0.18 & 3.27 \\
Suicide rate (female) & 1551 & 0.78 & 0.34 & 0.00 & 2.17 \\
Suicide rate (male) & 1551 & 1.97 & 0.63 & 0.00 & 4.69 \\
Unemployment benefit (total) & 1551 & 326.38 & 61.24 & 202.11 & 526.63 \\
Unemployment benefit (female) & 1551 & 375.74 & 73.20 & 225.50 & 607.71 \\
Unemployment benefit (male) & 1551 & 273.12 & 51.88 & 176.70 & 454.55 \\
Unemployment benefit (total, yoy) & 1551 & 12.25 & 38.01 & -137.25 & 191.96 \\
Unemployment benefit (female, yoy) & 1551 & 9.55 & 39.78 & -175.60 & 206.22 \\
Unemployment benefit (male, yoy) & 1551 & 15.20 & 38.51 & -94.49 & 187.69 \\
Emergency Small Ammount Funds & 893 & 28.51 & 55.85 & 0.00 & 567.45 \\
General Support Funds & 893 & 14.90 & 36.93 & 0.00 & 426.29 \\
Housing Security Benefit & 423 & 6.13 & 9.49 & 0.00 & 81.26 \\
Public assistance (recipients) & 1551 & 1398.27 & 666.37 & 332.39 & 3248.44 \\
Public assistance (households) & 1551 & 1103.91 & 514.65 & 289.87 & 2516.68 \\
Public assistance (recipients, yoy) & 1551 & -10.96 & 18.90 & -61.43 & 46.46 \\
Public assistance (households, yoy) & 1551 & 3.01 & 11.85 & -21.45 & 50.50 \\
Covariate & & & & & \\
Cumulative infection rate & 47 & 0.09 & 0.09 & 0.00 & 0.45 \\
Cumulative death rate & 47 & 0.00 & 0.01 & 0.00 & 0.02 \\
Google Mobility index & 47 & -22.18 & 4.86 & -39.05 & -12.87 \\
Population density & 47 & 1350.74 & 1781.23 & 234.70 & 9792.90 \\
Ratio of employees (secondary) & 47 & 0.25 & 0.05 & 0.14 & 0.33 \\
Ratio of employees (service) & 47 & 0.66 & 0.04 & 0.60 & 0.73 \\
Elderly dependency rate & 47 & 53.50 & 7.51 & 35.00 & 70.10 \\
Total population & 47 & 268.49 & 277.93 & 56.00 & 1392.00 \\
\hline
\end{tabular}

Notes: The employment shock is a cross-section variable calculated based on equation (1). All the other variables are calculated per 100,000 population. For the definition of each variable, see Table A.2 in Appendix A. Outcome variables such as suicide rates, unemployment benefits, and Public assitance recipients are 21-months data (from January 2019 to September 2020) while the variables of Emergency Small Amount Funds, General Support Funds, and Housing Security Benefit are more restricted due to data limitation. "yoy" means year-on-year difference.

Sources: See Table A.2 in Appendix A. 
medRxiv preprint doi: https://doi.org/10.1101/2020.11.16.20232850; this version posted November 24, 2021. The copyright holder for this preprint (which was not certified by peer review) is the author/funder, who has granted medRxiv a license to display the preprint in

It is made available under a CC-BY-NC-ND 4.0 International license .

statistics (labor force participation rate, employment rate, unemployment rate, and jobs-to-applicants ratio) and the outcome variables listed in Section 2.2. See also Table A.2 for their definitions and data sources.

The implications of Figure 1 are summarized as follows. First, panels (a) and (b) show that the employment rate and labor force participation (LFP) rate have sharply dropped since April 2020, while the unemployment rate and the jobs-to-applicants ratio (i.e., the ratio of job offers to job applicants) gradually deteriorated. ${ }^{8}$ Second, panels (c) and (d) suggest that suicide rates have been increasing since July $2020 .^{9}$ Third, panels (e) and (f) show that the utilization of the first and second-tier safety net programs also increased during and after the second quarter of 2020 or the period of the first wave of COVID-19. ${ }^{10}$ Fourth, panel (g) shows that the year-onyear numbers of recipients and recipient households of the public assistance program, the third-tierand last-resort safety net, are negative both before and after the onset of the COVID-19 crisis, implying that the number of public assistance recipients kept decreasing regardless of the COVID-19 crisis. Panel (h), however, indicates that the counterpart year-on-year number for the household type of "others", which includes low-income workers and the unemployed, clearly started increasing in April 2020.

In turn, Figure 2 shows the regional variation of the employment shock measured as equation (1) (panel (a)), namely our treatment variable, and correlations of this employment shock and changes in total, female, and male suicide rates in July 2020 from those in July 2019 (panel (b)-(d)). We use the monthly suicide rates in July because our employment-shock variable is calculated as a shock in the second quarter (i.e., April to June) 2020.

Panel (a) of Figure 2 shows that the most affected prefectures are Okinawa, Kanagawa, and Osaka and their employment shocks are more than one percentage point. Panel (a) also suggests that these employment shocks are larger in metropolitan areas (Kanagawa, Osaka, Nara, Tokyo, Hyogo, Saitama, Chiba, Kyoto) and prefectures with popular sightseeing spots (Okinawa and Hokkaido). Panels (b)-(d) present some positive correlations between the employment shock and the suicide

${ }^{8}$ See Table A.2 for the definitions of these employment-related variables.

${ }^{9}$ It is of course not clear from these graphs to what degree the COVID-19 crisis has led to the increase in suicides, but some specialists and reports in the mass media have asserted that the sharp deterioration in employment in the first few months of the COVID19 crisis may have resulted in the slightly lagged increase in suicides [38, 39]. In Table A.3 appendix A, we also present the numbers of suicides in 2019 and 2020 by sex, age and occupation and these data show that the increase in suicides from 2019 and 2020 stands out in both employed and non-employed women within all age cohorts and young employed men aged 20-29.

${ }^{10}$ Outcome values for all the second-tier programs are not zero in the pre-COVID-19 period but discontinuously smaller than those in the COVID-19 period. Note also that the central government has relaxed eligibility requirements for these second-tier programs due to COVID-19 since March 2020. 
medRxiv preprint doi: https://doi.org/10.1101/2020.11.16.20232850; this version posted November 24, 2021. The copyright holder for this preprint (which was not certified by peer review) is the author/funder, who has granted medRxiv a license to display the preprint in

It is made available under a CC-BY-NC-ND 4.0 International license .

Figure 1: Monthly trends of employment-related variables, suicides and safety-net programs
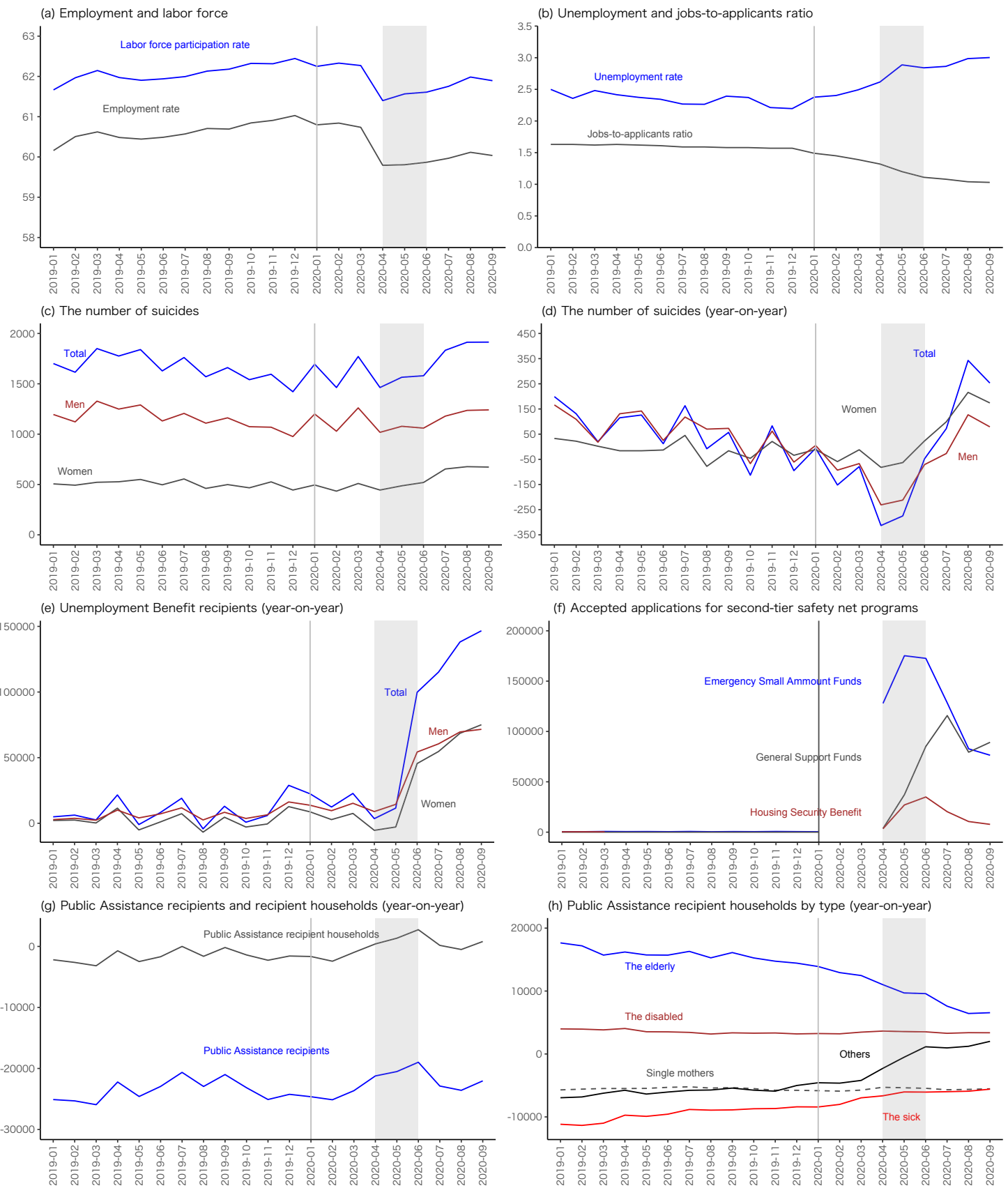

Notes: A vertical line in January 2020 indicates the beginning of the COVID-19 crisis in Japan and a gray area indicates the second quarter of 2020. "Year-on-year" means year-on-year difference. Panels (a) and (b) show different employment-related statistics. Suicides in panels (c) and (d) are counted based on the estimated dates of death. In panel (f), "Emergency Small Amount Funds" and "General Support Funds" are two public temporary loan programs and "Housing Security Benefit" is a temporary housing allowance program. In panel (h), "the elderly" indicates a household with only persons aged 65 or over (and unmarried persons under the age of 18), "single mothers" means households with unmarried women and their children under the age of 18, "the disabled" or "the sick" are households the heads of which are persons with a disability or illness respectively. See Section 2 for more details about these data.

Sources: See Table A.2 in Appendix A. 
medRxiv preprint doi: https://doi.org/10.1101/2020.11.16.20232850; this version posted November 24, 2021. The copyright holder for this preprint (which was not certified by peer review) is the author/funder, who has granted medRxiv a license to display the preprint in

It is made available under a CC-BY-NC-ND 4.0 International license .

Figure 2: Changes in the unemployment rate and suicide rates
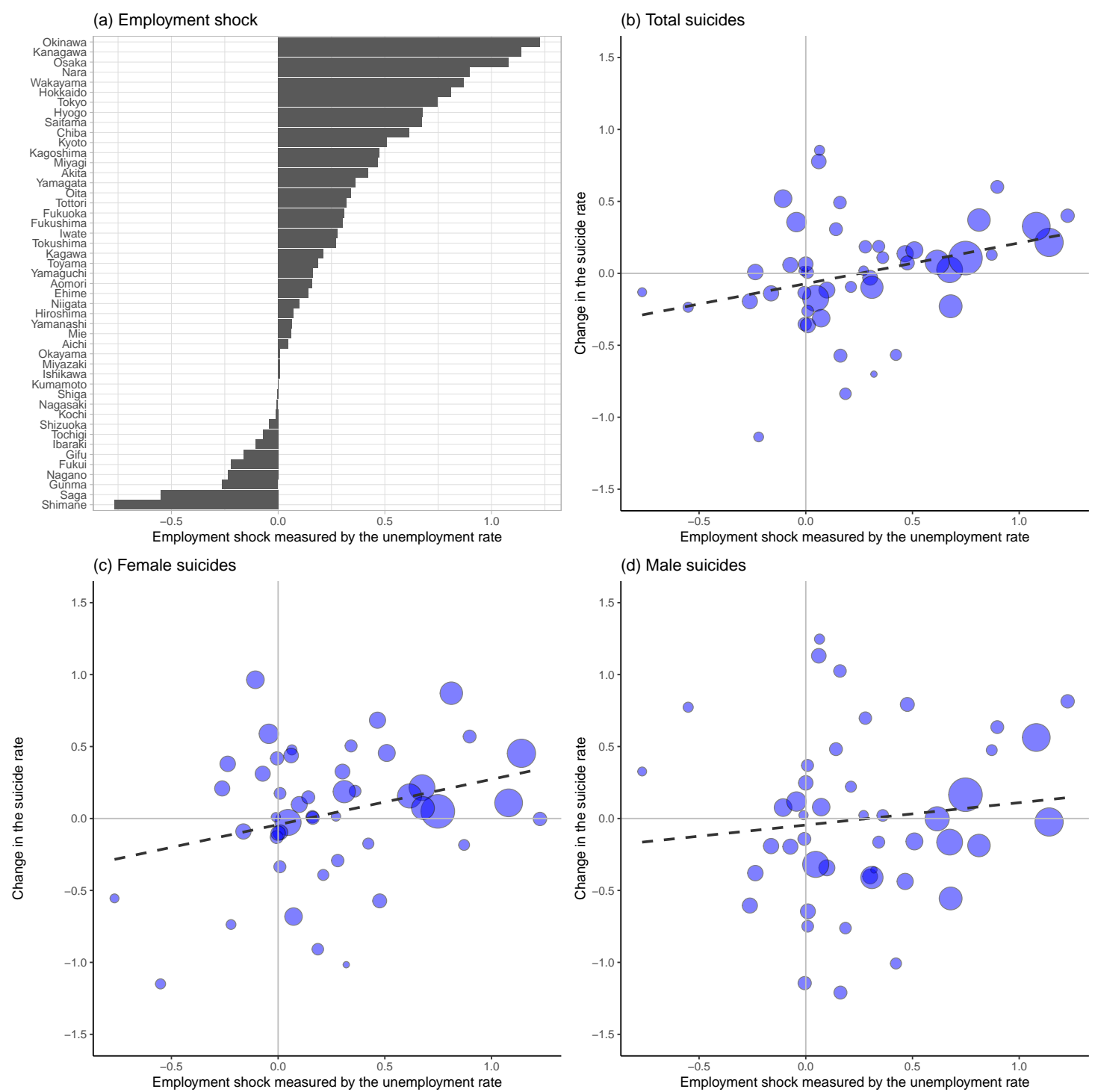

Notes: In all four graphs, the $X$ axis is the size of an employment shock defined as in (1). The $Y$ axis in panels (b)-(d) is a change in the suicide rate from July 2019 to July 2020. The size of each circle is based on the population size of each prefecture. The dashed line is the fitted linear regression line based on the Ordinary Least Square (OLS) method.

Sources: See Table A.2 in Appendix A

rates, although suicide rates in the metropolitan areas are not necessarily highest.

\section{Research design}

Exploiting the regional variation in the COVID-19-induced employment shock and a difference-in-difference research design, we examine how the regional trends of suicide and the use of safety net programs in the COVID-19 period are associated with the intensity of the regional employment shock. We also consider possible confounders that undermine the causal interpretation of our estimation results. 
medRxiv preprint doi: https://doi.org/10.1101/2020.11.16.20232850; this version posted November 24, 2021. The copyright holder for this preprint (which was not certified by peer review) is the author/funder, who has granted medRxiv a license to display the preprint in It is made available under a CC-BY-NC-ND 4.0 International license .

\subsection{Empirical model}

The baseline model specification takes the following event-study specification with time-varying DID coefficients:

$$
Y_{i t}=\sum_{\tau \neq \text { Jan.2020 }} \beta_{\tau} \text { EmpShock }_{i} \times 1[t=\tau]+\pi_{i}+\theta_{t}+\phi_{i} t+\varepsilon_{i t}
$$

where $Y_{i t}$ is the outcome variable such as a suicide rate for prefecture $i$ at time $t$, Empshock $_{i}$ is a continuous treatment variable of the COVID-19 employment shock defined as in (1), $1[t=\tau]$ is a dummy variable that takes the value of one if $t=\tau$ and zero otherwise, $\pi_{i}$ and $\theta_{t}$ are prefecture and month fixed effects, respectively, $\phi_{i} t$ is an individual (i.e., prefecture) linear trend, and $\varepsilon_{i t}$ is an error term.

The coefficients of interest are the time-varying coefficients $\beta_{\tau}$, which capture the correlation between EmpShock E $_{i}$ and the outcome trend from January 2020 to time $\tau$. When time $\tau$ is before January 2020, $\beta_{\tau}$ can be interpreted as a placebo estimate that is expected to be around zero if no confounding trends existed before the COVID-19 crisis. When month $\tau$ is after January 2020, $\beta_{\tau}$ is supposed to capture the effect of EmpShock $k_{i}$ on the outcome variable if the assumption of no differential trends among prefectures in the COVID-19 period is plausible.

In the baseline regression analysis we use the weighted least square (WLS) estimation method in which prefecture-level population sizes are used as weights. With this WLS model, the heterogeneous effect of the employment shock on an outcome for a larger prefecture is more highly weighted in a DID estimator. In the section of robustness checks, we also use the ordinary least square (OLS) estimation method because it is not clear whether a WLS estimator is more appropriate than an OLS estimator as an estimator of a population average effect when effect heterogeneity exists [40].

In addition, for the outcomes of the second-tier safety net programs (temporary loans and Housing Security Benefit), we do not include an individual linear trend $\phi_{i} t$ in the model (2) because the levels of these outcomes are negligible in the preCOVID-crisis period compared with the COVID-crisis period (see panel (f) in Figure 1). As robustness checks, we also provide estimation results of all of the other outcomes with an estimation model that does not control for individual linear trends.

One caveat other than the problem of possible confounders, which we will discuss in the next section, is that what we examine is the region-level (i.e., prefecture-level) association between the employment shock and the outcomes of interest. In this sense, we do not directly investigate how individual or household-level unemployment is related to individual or household-level suicide and safety net use. Instead, we examine how the prefecture-level employment shock is associated with suicide and safety net use for people and households living in each prefecture. In other words, the parameter $\beta_{\tau}$ reflects not only direct associations between individual 
medRxiv preprint doi: https://doi.org/10.1101/2020.11.16.20232850; this version posted November 24,2021 . The copyright holder for this preprint (which was not certified by peer review) is the author/funder, who has granted medRxiv a license to display the preprint in

It is made available under a CC-BY-NC-ND 4.0 International license .

unemployment and individual outcomes, but broader associations between deteriorating prefecture-level employment situations and the well-being and living standard of people and families living in a prefecture.

\subsection{Possible confounders}

Even if placebo estimates of $\beta_{\tau}$ before January 2020 in equation (2) are around zero, it is possible that some regional factors are correlated with both EmpShock $k_{i}$ and $Y_{i t}$ under the COVID-19 crisis, resulting in confounding bias in the estimation of $\beta_{\tau}$ after January 2020. Such confounding regional factors may exist given the fact that the impact of the COVID-19 crisis has spread through society via various pathways.

In order to mitigate such possible confounding bias, we also estimate the regression model that incorporates pre-determined cross-sectional covariates interacted with monthly dummy variables in the COVID-19 period. These terms capture the COVID-19-induced outcome changes that are better explained by pre-determined factors than by the COVID-19 employment shock. ${ }^{11}$

For these covariates, we use the three variables that reflect the intensity of the COVID-19 crisis and the five variables that represent pre-COVID-19 demographic conditions. The three covariates of the COVID-19 crisis consist of the cumulative COVID-19 infection and death rates at the end of the first wave (i.e., at the end of June 2020 based on Figure A.1) and the monthly average of the Google Mobility index in May 2020, when the first COVID-19 state of emergency was imposed. ${ }^{12}$ All of these variables may affect both the employment shock and the outcomes of interest and may cause omitted variables bias. The five demographic variables are the population density measured by inhabitable area, the ratios of employees in the secondary and tertiary (i.e., service) industry, the population size, and the elderly dependency rate (i.e., the ratio between the number of persons aged 65 and over and the number of persons aged between 15 and 64). See Table 1 for the summary statistics of the eight covariates.

We do not strongly argue that our empirical strategy and the inclusion of the above eight covariates perfectly solve the problem of estimation bias. In this sense,

\footnotetext{
${ }^{11}$ Time-varying covariates, which are more commonly used in the DID literature, cannot be obtained in our analysis with monthly panel data.

${ }^{12}$ The Google mobility data is taken from Google COVID-19 Community Mobility Reports [41]. Google provides prefectural data on people's visits to six categories of places such as "Grocery and pharmacy", "Retail and recreation", "Parks", "Transit stations", "Workplace", and "Residential". Each indicator shows the percentage change in the number of visitors to (or time spent in) different locations compared to the baseline number computed from January 3rd and February 6th, 2020. Using four of these mobility measures ("Grocery and pharmacy', "Retail and recreation", "Transit stations", and "Workplace") , we calculated the monthly average values of Google Mobility indicators, following the definition of [42] and [43]. See also Figure A.2 for nation-level time-series statistics of this mobility index in 2020 .
} 
medRxiv preprint doi: https://doi.org/10.1101/2020.11.16.20232850; this version posted November 24, 2021. The copyright holder for this preprint (which was not certified by peer review) is the author/funder, who has granted medRxiv a license to display the preprint in

It is made available under a CC-BY-NC-ND 4.0 International license .

we interpret our estimation results as associations between the COVID-19-induced employment shock and the outcomes of interest, which nonetheless are expected to reflect causal relations from the former to the latter.

\subsection{Suicide prevention by safety net}

Another limitation of our research design is that we interpret safety net use as an outcome of financial distress rather than an indicator of financial aid. That is, although it is important to understand how the safety net programs have prevented suicide under the COVID-19 crisis, we do not address this question in this paper. This may be disappointing, but the incidences of suicide and safety net use are expected to be strongly endogenous and we cannot find any proper exogenous variation that can solve this endogeneity problem.

This limitation, however, does not lead to any confounding bias in our estimation of $\beta_{\tau}$ because the endogenous relationship between outcome variables is not relevant for our identification strategy. We only need to interpret the association between the COVID-19-induced employment shock and the suicide rate as the one that remained even after the three tiers of safety net programs and other financial benefits contributed to suicide prevention during and after the first wave of COVID-19.

\section{Results}

This section provides baseline estimation results based on WLS regression with and without covariates. We present results for suicide rates and the three tiers of safety net programs separately.

\subsection{Suicide rates}

Figure 3 shows the estimation results for the suicide rates: the left-hand graphs are estimation results based on model (2) using WLS and the right-hand graphs show counterpart results based on a model that additionally controls for the eight covariates. First, DID estimates in the pre-COVID-19 period are more or less zero, implying that there is no clear statistically significant correlation between the employment shock and all the outcome trends before January 2020. Second, after January 2020, DID estimates for total, female, and male suicide rates are positive from May to July and the lower limits of the $90 \%$ confidence intervals are often above or near zero, particularly in July.

Comparing results in the COVID-19 period between the models without the covariates (right-hand) and with the covariates (left-hand), estimation results are robust in the sense that the positive estimates in July 2020 remain the same. Given that the right-hand results are less biased in the sense that some possible confounding 
medRxiv preprint doi: https://doi.org/10.1101/2020.11.16.20232850; this version posted November 24,2021 . The copyright holder for this preprint (which was not certified by peer review) is the author/funder, who has granted medRxiv a license to display the preprint in It is made available under a CC-BY-NC-ND 4.0 International license .

factors are controlled for, in the rest of this paper we discuss the results based on the right-hand graphs. 13

The sizes of the estimates in July 2020 based on the right-hand graphs suggest that the one-percentage-point increase in the COVID-19 employment shock in the second quarter of 2020 is associated with $0.522,0.518$, and 0.521-point increases (or $37.4 \%, 60.5 \%$, and $26.5 \%$ increases from July 2019) in the total, female, and male suicide rates respectively. ${ }^{14}$ In August and September, estimates are around zero, implying that suicides in these months may not directly be related to the second-quarter employment shock in 2020.

Overall, the DID estimates suggest that the COVID-19-induced employment shocks are clearly associated with both female and male suicides. Estimates are more or less robust to the inclusion of the covariates at least in July 2020, just after the second-quarter employment shock. This indicates that confounding bias may not be serious and causal interpretation is somewhat plausible. At the same time, the association between the employment shock and the suicide rate is not clearly observed in August and September 2020 and this finding is also robust to the introduction of the covariates. This implies that the COVID-19 employment shock in the second quarter of 2020 may have a short-run impact on suicide in the following month of July 2020, but cannot explain suicide increases in August and September 2020.

The magnitudes of the estimated impacts in July 2020 are not small. Simple calculation based on the estimate for total suicides in panel (b) suggests that if a region with a population of 10 million experienced a one-percentage point increase in the unemployment rate caused by the COVID-19 crisis in the second quarter of 2020, which is roughly equivalent to the third-highest employment shock on Osaka (see Figure 2), this could have led to an additional 52.2 suicides in July 2020. Another simplified back-of-envelop calculation suggests that if Japan experienced the same one-percentage-point employment shock and there was a homogeneous nationwide employment-shock effect of a 0.522 point increase, this could have led to an additional 658 suicides when the counterpart monthly suicide number was 1,761 in July 2019. ${ }^{15}$

\footnotetext{
${ }^{13} \mathrm{We}$ also interpret that larger confidence intervals in some estimates after controlling for the covariates are partly due to correlations among the treatment variable and the eight covariates: some of the Variable Inflation Factors (VIFs) based on a cross-sectional OLS regression using the treatment and the eight covariates as independent variables exceed or are close to 10 . This implies that an imperfect multicollinearity problem may occur in some estimations with the nine independent variables under a relatively small sample size. We nonetheless use all eight covariates because (1) we do not know which covariate(s) mitigate confounding bias and (2) VIF of the treatment variable itself is 1.87 and relatively low.

${ }^{14}$ The rates of increase are calculated as the estimates divided by the total, female, and male suicide rates in July 2019, which are 1.394, 0.856, and 1.963 respectively.

${ }^{15} 658$ is calculated as 1,260 times 0.522 , where 1260 hundred thousand (i.e. 126 million)
} 
medRxiv preprint doi: https://doi.org/10.1101/2020.11.16.20232850; this version posted November 24, 2021. The copyright holder for this preprint (which was not certified by peer review) is the author/funder, who has granted medRxiv a license to display the preprint in

It is made available under a CC-BY-NC-ND 4.0 International license .

Figure 3: DID estimates for suicide rates

(a) Total

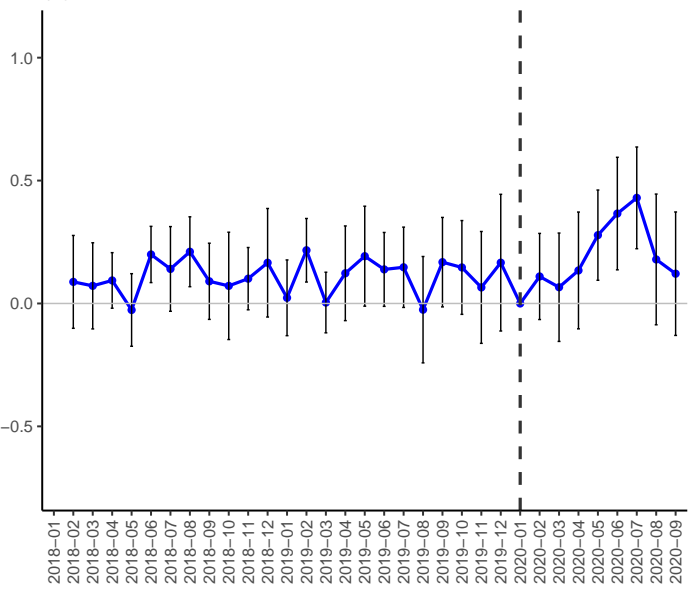

(c) Female

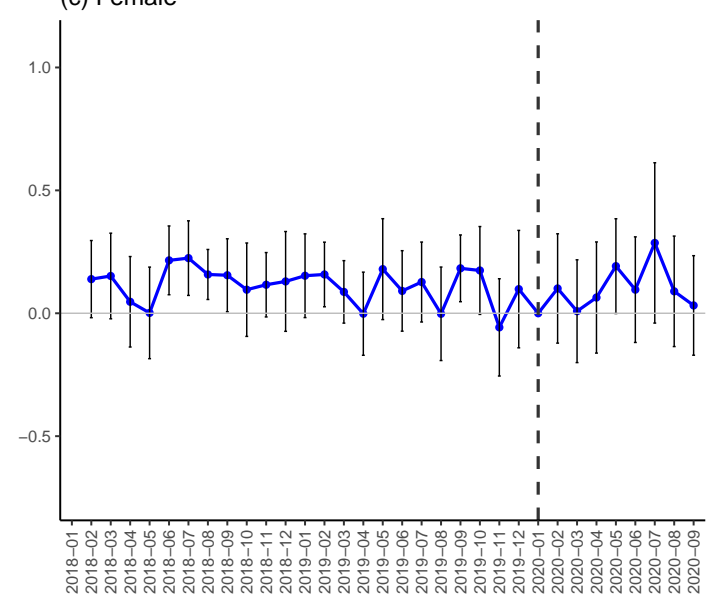

(e) Male

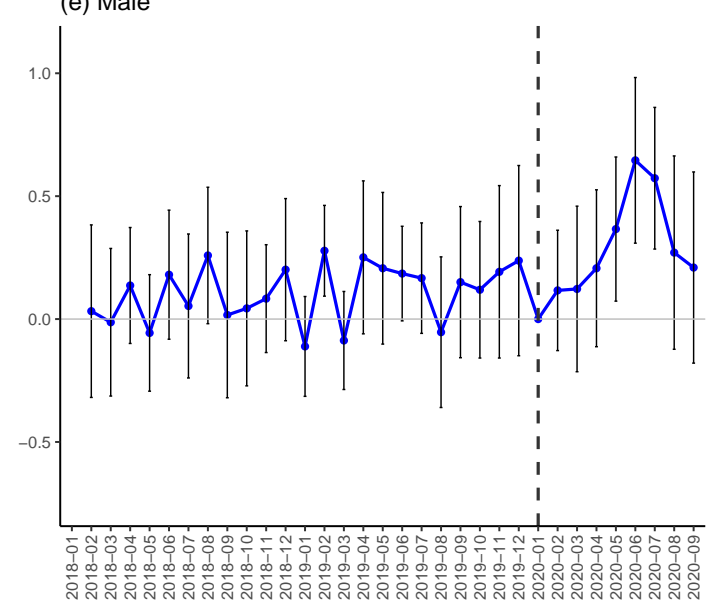

(b) Total, with covaraites

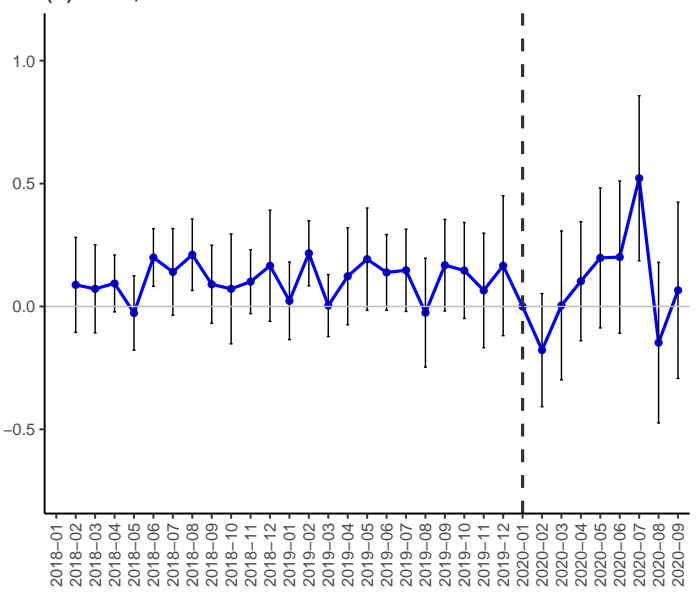

(d) Female, with covaraites

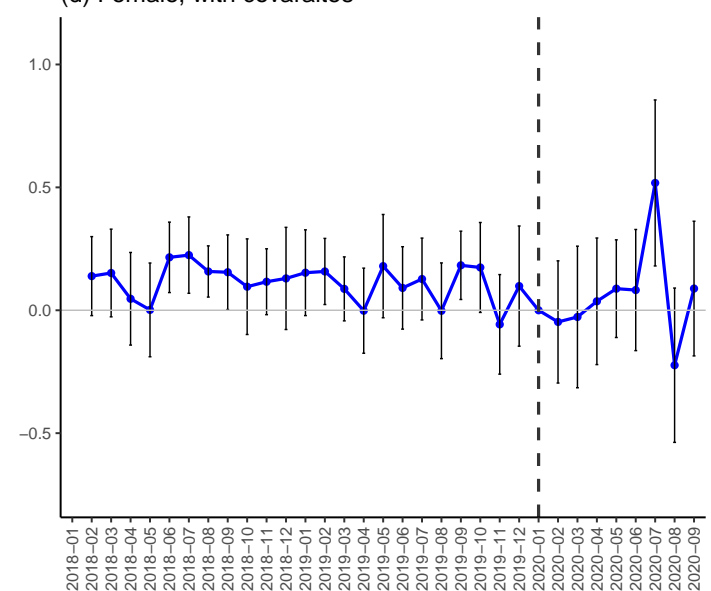

(f) Male, with covaraites

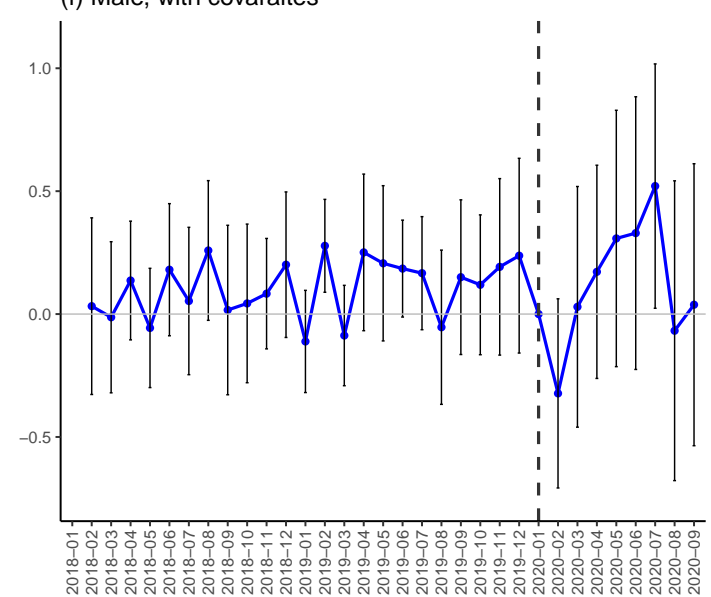

Notes: Each plot indicates a point estimate and a vertical line indicates a $90 \%$ confidence interval that is calculated based on a robust standard error clustered at the prefecture level. All the outcomes are measured as the number of suicides per 100,000 people and the treatment variable is the COVID-19-induced employment shock, which is calculated as equation (1). Estimates are obtained based on equation (2) with WLS estimation weighted by prefecture population size. Because equation (2) incorporates individual (i.e. prefecture) linear trends, estimates can be obtained from February 2019. See Tables C.1 and C.2 for the values of these baseline estimates and standard errors in the COVID-19 period. 
medRxiv preprint doi: https://doi.org/10.1101/2020.11.16.20232850; this version posted November 24, 2021. The copyright holder for this preprint (which was not certified by peer review) is the author/funder, who has granted medRxiv a license to display the preprint in It is made available under a CC-BY-NC-ND 4.0 International license.

\subsection{Safety net use}

When it comes to the relation between the COVID-19-induced employment shock and safety net programs, we provide three figures that represent estimation results for the first, second, and third-tier safety net programs respectively.

First, Figure 4 provides estimation results for year-on-year unemployment benefit numbers, the first-tier safety net. ${ }^{16}$ As in Figure 3, the left-hand results are based on model (2) using WLS and the right-hand results are based on the model that controls for the eight covariates. To begin with, estimates are slightly increasing but not significantly different from zero in the COVID-19 crisis period if no covariates are introduced in the regression model (left graphs). However, after controlling for the covariates, estimates in the COVID-19 period get larger for all three outcomes, particularly for the outcome of female recipients (right graphs). In July 2020, the one-percentage-point increase in the employment shock is associated with approximately an additional 27.9 total unemployment benefit recipients per 100,000 population (panel (b)).

Second, Figure 5 provides estimates for the second-tier safety net programs: the two temporary loan programs and the Housing Security Benefit. In the COVID-19 period, panels (a) to (d) show that the estimates for the temporary loan programs in the COVID-19 periods are positive and these results are robust to the inclusion of the covariates, while the lower limits of the confidence intervals in panel (b) are below zero in the COVID-19 period. Panel (e) shows a positive association between the employment shock and Housing Security Benefit in the COVID-19 period, but it disappears once the covariates are controlled for in panel (f). At the peak, the one-percentage-point increase in the employment shock is associated with an additional 87.8 accepted applications for General Support Funds in July 2020 (both per 100,000 population, panel (d)). Note that the numbers of accepted applications for these programs are discontinuously smaller in the pre-COVID-19 period, so the pre-COVID-19 estimates and confidence intervals can be obtained but are negligibly smaller than those in the COVID-19 period. This may be one drawback of the examination of pre-trends for these outcomes, but it also means that there are at least no significant differential trends for these outcomes in the pre-COVID-19 period. ${ }^{17}$ We also do not incorporate individual linear trends due to this feature.

\footnotetext{
${ }^{16}$ We also use the original outcome but some monthly fluctuations in pre-COVID-19 estimates are not properly controlled for when we use it as an outcome variable.

${ }^{17}$ As for the Housing Security Benefit, for which we have very limited prefecture-level monthly data in the pre-COVID-19 period (i.e., only January to March 2019), we at least know that the number of accepted applications discontinuously increased in 2020 at the national level: the average monthly number of accepted applications in fiscal year 2019 (from April 2019 to March 2020) in the whole of Japan was only 331, whereas the corresponding numbers in April, May, and June 2020 were 3,409, 27040, and 34,867 respectively (based on the statistics of MHLM).
} 
medRxiv preprint doi: https://doi.org/10.1101/2020.11.16.20232850; this version posted November 24,2021 . The copyright holder for this preprint (which was not certified by peer review) is the author/funder, who has granted medRxiv a license to display the preprint in

Figure 4: DID estimates for unemployment benefit recipients

(a) Total

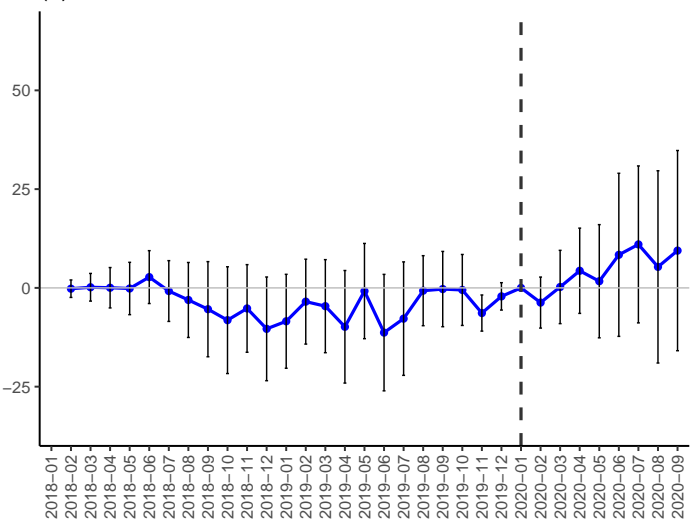

(c) Female

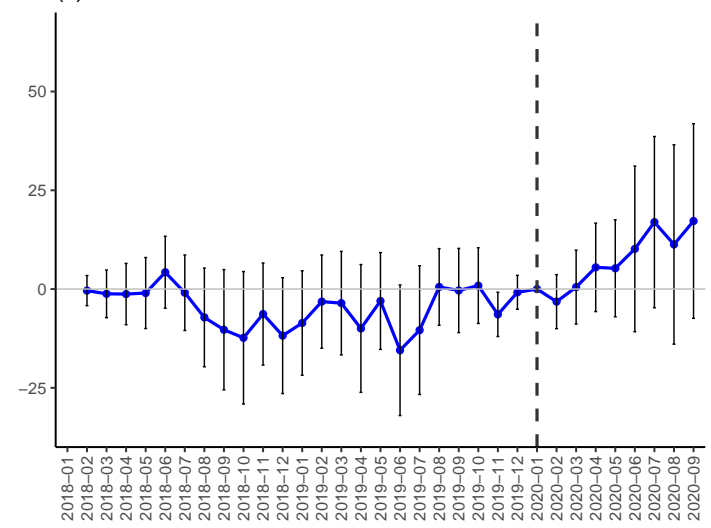

(e) Male

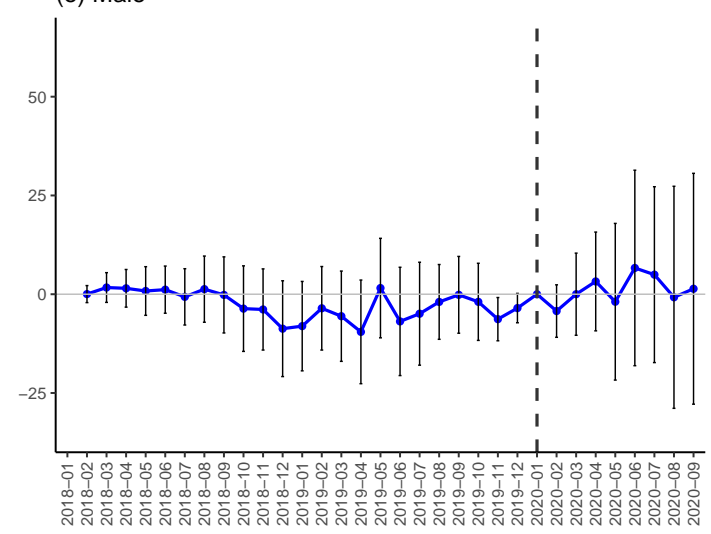

(b) Total, with covaraites

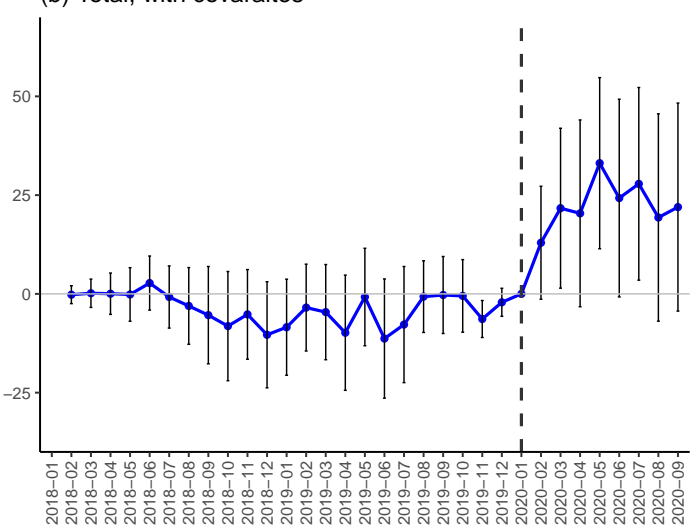

(d) Female, with covaraites

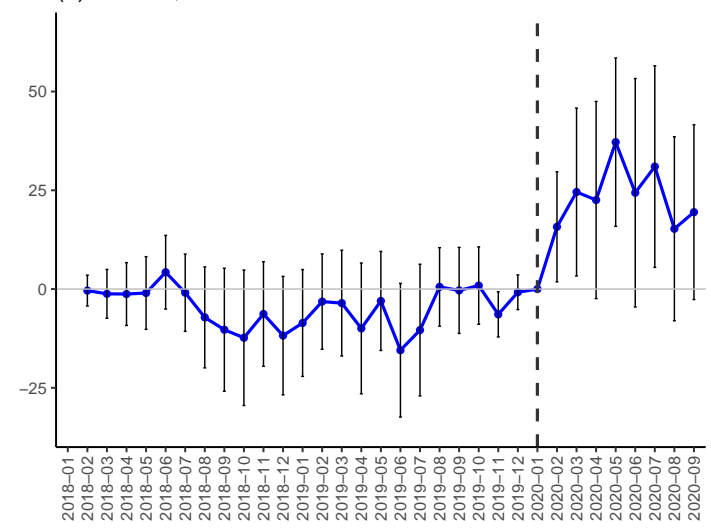

(f) Male, with covaraites

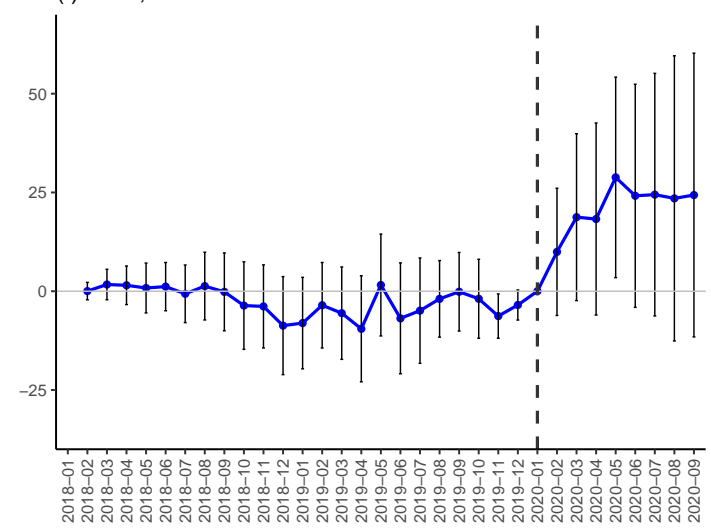

Notes: Each plot indicates a point estimate and a vertical line indicates a $90 \%$ confidence interval that is calculated based on a robust standard error clustered at the prefecture level. All the outcomes are measured as the number of recipients per 100,000 people and the treatment variable is the COVID-19-induced employment shock, which is calculated as equation (1). An outcome variable is year-on-year and calculated as the difference between an outcome value at month $t$ and an outcome value at month $t-12$. Estimates are obtained based on equation (2) with WLS estimation weighted by prefecture population size. Because equation (2) incorporates individual (i.e. prefecture) linear trends, estimates can be obtained from February 2019. See Tables C.3 and C.4 for the values of these baseline estimates and standard errors in the COVID-19 period.

Third, Figure 6 provides estimation results for year-on-year public assistance benefits: panels (a) and (b) present estimates for the number of recipients and panels (c) and (d) for the number of recipient households. ${ }^{18}$ All of the graphs

${ }^{18}$ We also use the original outcome but differential trends are not properly eliminated 
medRxiv preprint doi: https://doi.org/10.1101/2020.11.16.20232850; this version posted November 24, 2021. The copyright holder for this preprint (which was not certified by peer review) is the author/funder, who has granted medRxiv a license to display the preprint in

It is made available under a CC-BY-NC-ND 4.0 International license .

Figure 5: DID estimates for second-tier safety net programs

(a) Emergency Small Amount Funds

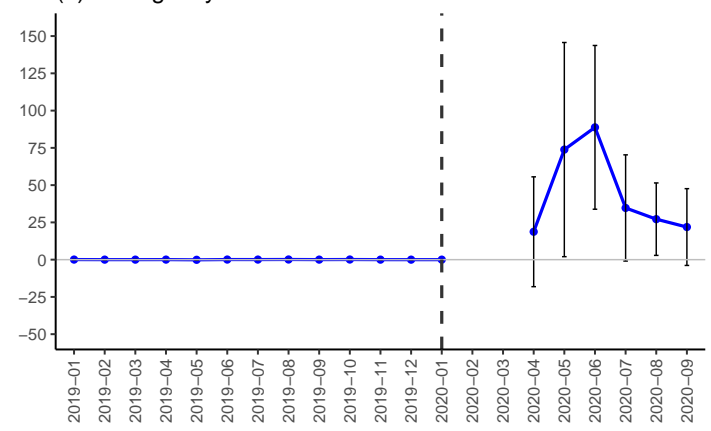

(c) General Support Funds

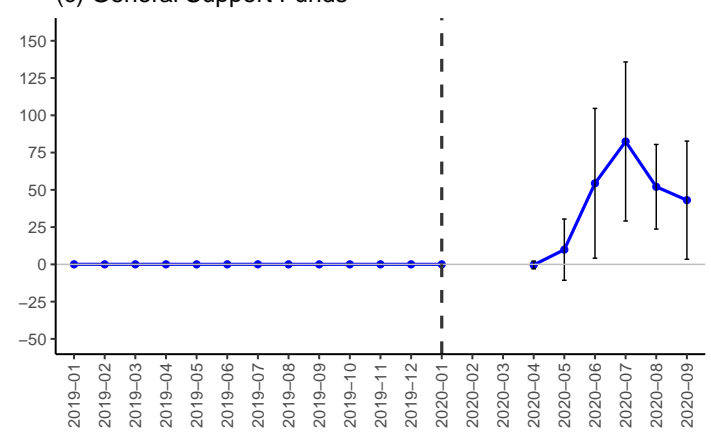

(e) Housing Security Benefit

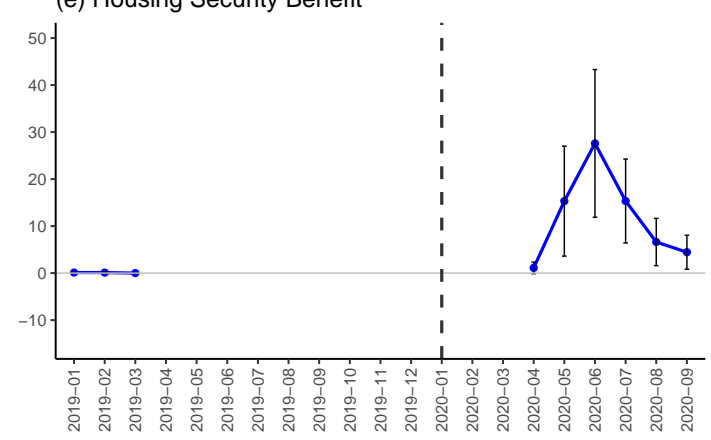

(b) Emergency Small Amount Funds, with covariates

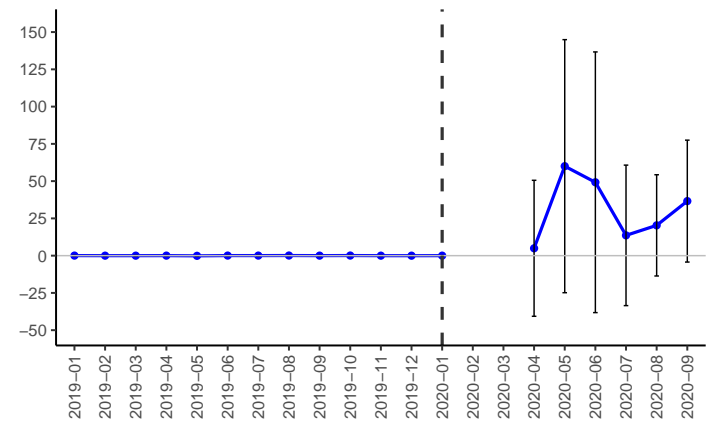

(d) General Support Funds, with covariates
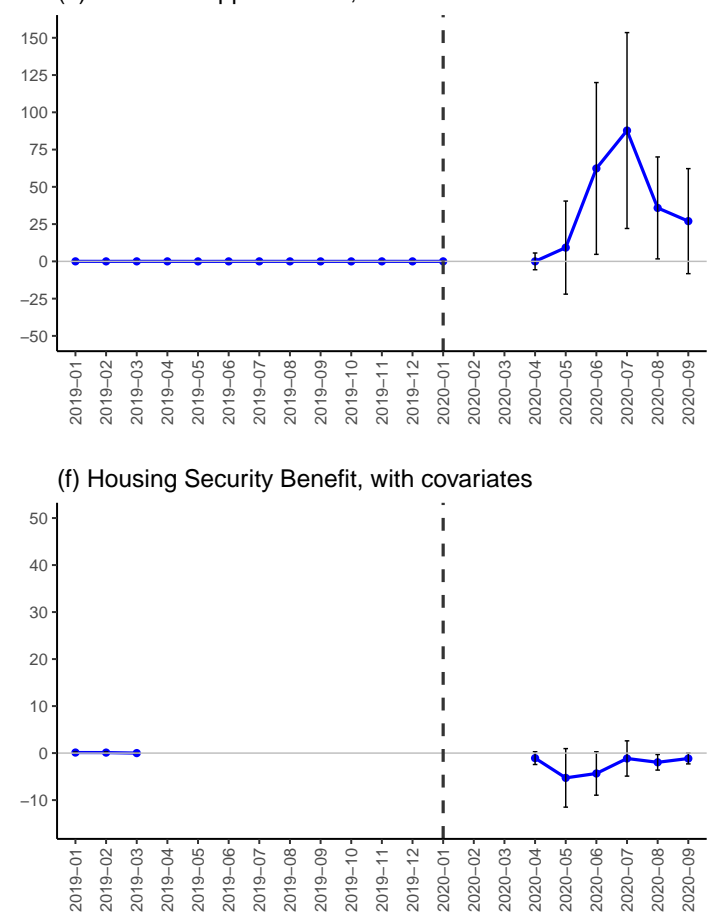

Notes: Each plot indicates a point estimate and a vertical line indicates a $90 \%$ confidence interval that is calculated based on a robust standard error clustered at the prefecture level. All of the outcomes are measured as the number of accepted applications per 100,000 people and the treatment variable is the COVID-19-induced employment shock, which is calculated as equation (1). Estimates are obtained based on equation (2) with WLS estimation weighted by prefecture population size. Individual linear trends are not introduced due to discontinuously smaller outcome values in the pre-COVID-19 period. For the outcome of Emergency Small Amount Funds and General Support Funds, data for February and March 2020 is missing. For the outcome of the Housing Security Benefit, the reference year is March 2019 instead of January 2020 due to the lack of data during April 2019 and March 2020. See Tables C.5 and C.6 for the values of these baseline estimates and standard errors in the COVID-19 period.

show that estimates in the COVID-19 period are clearly increasing and positive while estimates in the pre-COVID-19 period are around zero. Introduction of the covariates leads to smaller estimates and larger confidence intervals in the COVID-19 period, but baseline findings remain the same. ${ }^{19}$ The one-percentage-point increase for this outcome, particularly when individual linear trends are not incorporated.

${ }^{19}$ As discussed in footnote 13 , these larger confidence intervals may be explained by correlations among the nine independent variables (i.e., the treatment and the eight covariates). 
medRxiv preprint doi: https://doi.org/10.1101/2020.11.16.20232850; this version posted November 24, 2021. The copyright holder for this preprint (which was not certified by peer review) is the author/funder, who has granted medRxiv a license to display the preprint in It is made available under a CC-BY-NC-ND 4.0 International license .

in the employment shock is associated with approximately an additional 9.7 and 11.6 public assistance recipients per 100,000 population in July and September 2020, respectively (panel (b)).

Figure 6: DID estimates for public assistance

(a) Recipients

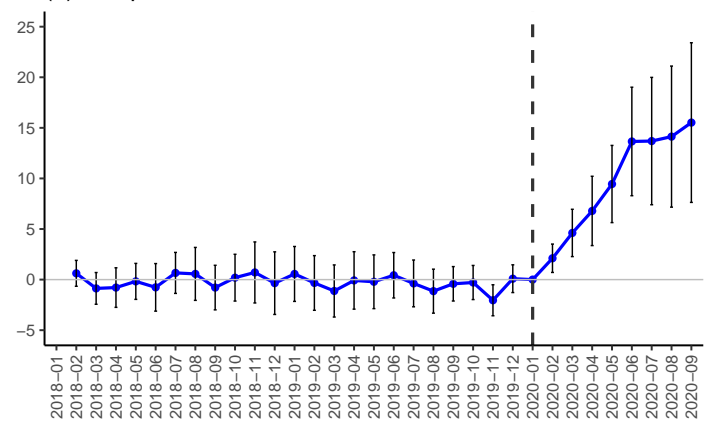

(c) Recipient households

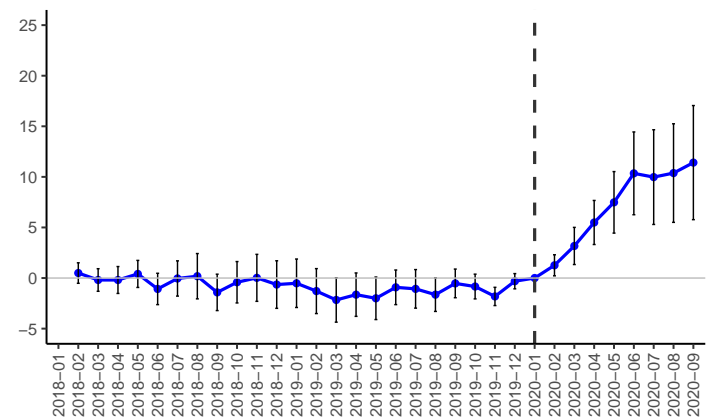

(b) Recipients, with covaraites

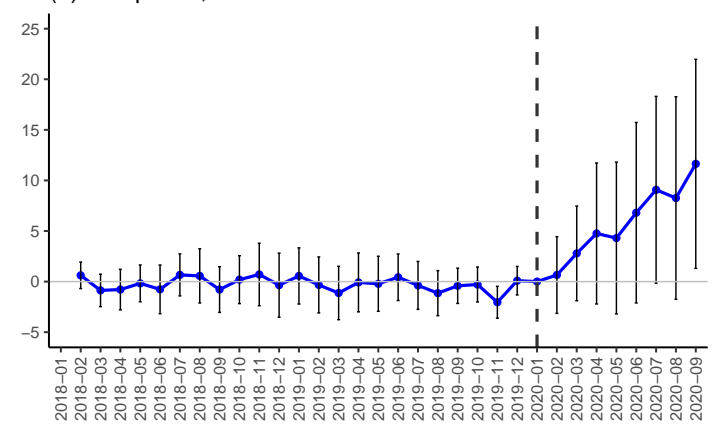

(d) Recipient households, with covaraites

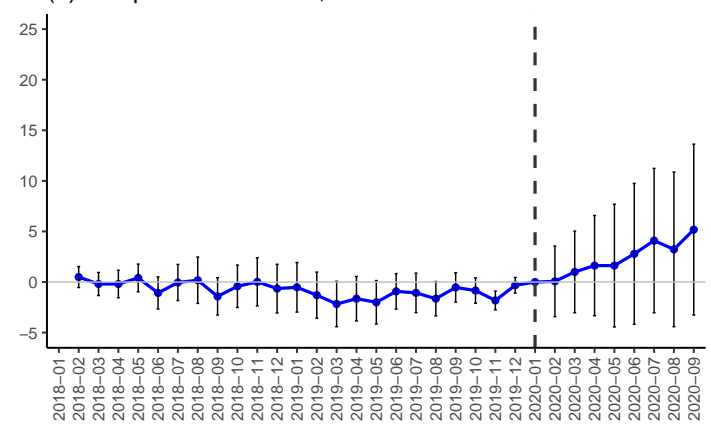

Notes: Each plot indicates a point estimate and a vertical line indicates a $90 \%$ confidence interval that is calculated based on a robust standard error clustered at the prefecture level. All of the outcomes are measured as the number of recipients or recipient households per 100,000 people and the treatment variable is the COVID-19-induced employment shock, which is calculated as equation (1). An outcome variable is year-on-year and calculated as the difference between an outcome value at month $t$ and an outcome value at month $t-12$. Estimates are obtained based on equation (2) with WLS estimation weighted by prefecture population size. Because equation (2) incorporates individual (i.e. prefecture) linear trends, estimates can be obtained from February 2019. See Tables C.7 and C.8 for the values of these baseline estimates and standard errors in the COVID-19 period.

Overall, these estimation results imply that the employment shock under the COVID-19 is positively associated with increases in safety-net utilization in all three tiers of programs in the COVID-19 period. The maximum estimate for each outcome suggests that a higher employment shock results in higher utilization. This effect is stronger in the case of the two temporary loan programs in the second-tier of the safety net then in the case of the unemployment benefit, which is the first-tier program. Smaller estimates for unemployment-benefit utilization than those for the temporary loan programs may be explained by the fact that the unemploymentbenefit coverage rate is low in Japan and that COVID-19-induced employment shocks are more concentrated on contingent workers who are often not eligible for unemployment benefits (Section 2.2).

In addition, even smaller estimates for the third-tier program of public assistance suggests that people facing unemployment and income reduction under the COVID- 
medRxiv preprint doi: https://doi.org/10.1101/2020.11.16.20232850; this version posted November 24, 2021. The copyright holder for this preprint (which was not certified by peer review) is the author/funder, who has granted medRxiv a license to display the preprint in

It is made available under a CC-BY-NC-ND 4.0 International license .

19 crisis tend to rely on the temporary loan programs rather than public assistance. Given the fact that these temporary loan programs were rarely used in the preCOVID-19 period, the role of these programs as a safety net in the COVID-19 crisis stands out.

Finally, while the estimates for the temporary loan programs peaked in June or July 2020 (Figure 5), the estimates for public assistance continued to increase through the third quarter of 2020 (Figure 6). This may imply that a certain portion of the unemployed people who used the second-tier safety net programs had to move to public assistance, because the second-tier programs are temporary and their loan and benefit levels are rather limited.

\section{Robustness checks}

This section provides three different robustness checks. First, we implement regressions using different estimation settings while using the same treatment and outcome variables. Second, we change the reference period from January 2020 to all pre-COVID-19 months in the sample, namely January 2020 and earlier. Third, we re-analyze the same baseline models using an alternative treatment variable discussed in Section 2.3.

\subsection{Weighting and individual trends}

Our first robustness check is to present estimation results based on two regression weighting schemes (OLS or WLS) and two model specifications (with or without individual linear trends $\phi_{i} t$ in equation (2)), using the same treatment and outcome variables as in the baseline estimation. The rationales for these robustness checks are as follows. First, as Solon et al.[40] argue, it is not clear a priori whether OLS or WLS regression is more suitable for estimating a population average effect, so we compare OLS and WLS estimates and discuss how they differ and why. Second, while incorporating individual linear trends may be effective for controlling for observed and unobserved differential trends across prefectures, it is useful to examine whether estimation results change if we use a simpler model without individual linear trends.

Estimation results in Appendix B suggest that our primary findings for suicide and all the safety net programs are robust to these different estimation settings except for a few cases. First, Figure B.1 shows that estimates for total, female, and male suicide rates in July 2020 are positive and mostly significantly different from zero regardless of estimation settings and the addition of the covariates. Second, Figure B.2 illustrates that estimates for unemployment benefit recipients are also increasing during the COVID-19 period although some estimates for male unemployment benefit recipients are not significantly different from zero. Third, in Figure B.3, 
medRxiv preprint doi: https://doi.org/10.1101/2020.11.16.20232850; this version posted November 24,2021 . The copyright holder for this preprint (which was not certified by peer review) is the author/funder, who has granted medRxiv a license to display the preprint in

It is made available under a CC-BY-NC-ND 4.0 International license .

estimation results for the second-tier programs (i.e., temporary loans and Housing Security Benefits) do not change much under different weighting schemes. ${ }^{20}$ Fourth, Figure B.4 shows, once individual trends are controlled for, both OLS and WLS estimates for public assistance are increasing and positive in the COVID-19 period regardless of the introduction of the covariates, although standard errors are larger if the covariates are incorporated. ${ }^{21}$

For most outcomes, WLS estimates during the COVID-19 period tend to be higher than the counterpart OLS estimates. We interpret larger WLS estimates as reflecting heterogeneous employment-shock effects across prefectures: as Figure 2 indicates, prefectures with larger populations may be more clearly associated with the employment shocks and the WLS estimation puts more weights on these prefectures.

\section{$5.2 \quad$ A different reference period}

We also provide a different robustness check in which all months before January 2020 are included in the reference period in addition to January 2020 as follows:

$$
Y_{i t}=\sum_{\tau>J a n .2020} \beta_{\tau} \text { EmpShock }_{i} \times 1[t=\tau]+\pi_{i}+\theta_{t}+\phi_{i} t+\varepsilon_{i t}
$$

where the notation of $\tau \neq \operatorname{Jan.2020}$ in model (2) is changed to $\tau>\operatorname{Jan.2020.}$ Because the pre-COVID-19 outcome trends are not correlated with the treatment variable in the baseline estimations based on model (2), including all pre-COVID19 months in the reference period may improve precision by averaging out noise in monthly pre-COVID-19 outcomes without increasing estimation bias.

Appendix $\mathrm{C}$ provides the estimation results of this robustness check for the suicide rates (Tables C.1 and C.2), unemployment benefit recipients (Tables C.3 and C.4), second-tier safety net programs (C.5 and C.6), and public assistance (Tables C.7 and C.8). In each table, we also provide the baseline estimates in the COVID-19 period that are presented in Figures 3, 4, 5 and 6 for comparison.

The estimation results of these robustness checks show that we robustly observe similar findings to those in the baseline estimations when we change the reference period from one pre-COVID-19 month to all pre-COVID-19 months. ${ }^{22}$ This implies that our results are not driven by specific pre-COVID-19 outcome values in January 2020 .

\footnotetext{
${ }^{20} \mathrm{We}$ do not incorporate linear individual trends in both the baseline and robustness analyses for the second-tier programs due to discontinuously smaller pre-COVID-crisis outcome values.

${ }^{21}$ Pre-COVID-19 estimates for public assistance outcomes fail to be around zero and positive if individual linear trends are not incorporated. This implies that DID estimates in the COVID-19 period under this specification have a downward bias.

${ }^{22}$ For the second-tier safety net programs, the inclusion of all pre-COVID-19 months in the reference period results in only subtle changes in estimates because their pre-COVID19 benefit levels are discontinuously smaller than those in the COVID-19 period.
} 
medRxiv preprint doi: https://doi.org/10.1101/2020.11.16.20232850; this version posted November 24, 2021. The copyright holder for this preprint (which was not certified by peer review) is the author/funder, who has granted medRxiv a license to display the preprint in It is made available under a CC-BY-NC-ND 4.0 International license .

\subsection{An alternative treatment}

As a final robustness check, in Appendix D we present DID estimation results using an alternative treatment variable of the "full-time" employment shock described in Section 2.3. We provide estimation results based on all four estimation schemes presented in Section 5.1: OLS without linear trends, OLS with linear trends, WLS without linear trends, and WLS with linear trends.

Our estimation results can be summarized as follows. First, contrary to our main findings, estimates for suicide in the COVID-19 period are not significantly different from zero regardless of the addition of the covariates (Figures D.1). Second, estimation results for all three tiers of safety net programs are similar to the baseline results in the sense that estimates are often positive and significantly different from zero in the COVID-19 period (Figures D.2, D.3, and D.4). Significant decreases in estimates for Housing Security Benefit with the introduction of the covariates are also observed in this alternative analysis (Figure D.3). ${ }^{23}$

No significant association between the "full-time" employment shock and suicide may be explained by the fact that the baseline employment shocks and the "full-time" employment shocks capture partly different COVID-19-induced economic shocks. In fact, Figure D.5 shows that the baseline employment shocks (X axis) are largest in prefectures in metropolitan areas or with popular sightseeing spots (e.g. Okinawa, Kanagawa, Osaka, Nara, Hokkaido, Hyogo, Tokyo, Saitama, Chiba, and Kyoto) whereas the alternative "full-time" employment shocks (Y axis) tend to be largestin prefectures with major manufacturing regions (e.g. Gifu, Aichi, Shizuoka, Shiga, Hiroshima, Toyama, and Mie). We speculate that there being no correlation between the "full-time" employment shocks and suicide is related to the fact that registered full-time-job seekers, who are taken into account in this alternative treatment variable, are more resilient to the risk of suicide. This may be related to the fact that registered full-time-job seekers are often eligible for unemployment benefits, but further investigation is required.

\section{Discussion and conclusion}

Exploiting regional variations in the employment shocks caused by the COVID-19 crisis, this paper examines whether the COVID-19-induced employment shocks in the second quarter of 2020 are associated with increases in suicide and safety net use in the second and third quarters of 2020.

Our estimation results suggest that the COVID-19-induced increase in unemploy-

\footnotetext{
${ }^{23}$ At the same time, estimates for unemployment benefit recipients are smaller when the covariates are incorporated (Figure D.2) and modest pre-trends are observed in the results for public assistance outcomes (Figure D.4). These results also suggest that the "full-time" employment shocks have different characteristics than the baseline employment shocks.
} 
medRxiv preprint doi: https://doi.org/10.1101/2020.11.16.20232850; this version posted November 24, 2021. The copyright holder for this

ment is associated with both suicide rates and safety net utilization. Assuming that causal interpretation is valid, the estimated effect sizes are not socio-economically negligible. For example, let us consider a stylised region or prefecture with a population of 10 million where the COVID-19-induced economic shock is one percentage point in the second quarter of 2020 under the first COVID-19 state of emergency. In this region, this employment shock would then result in an additional 52 suicides, 8,780 recipients of a temporary loan program, and 970 recipients of public assistance in July 2020.

In particular, the estimated effect sizes for suicide rates in our analysis are much higher than the corresponding previous estimates. Although previous studies use different data (mostly cross-country or cross-region yearly panel data) and different research designs (including correlational studies without explicit empirical strategies), our baseline estimate of a $37.4 \%$ increase in the suicide rate associated with a one-percentage-point increase in the unemployment rate is much higher than has been observed in the past. For example, the baseline estimate in Ruhm [20] is a $1.3 \%$ increase in the suicide rate. A systematic review of Fransquilho et al. [31] examines and summarizes many related studies, some of which show that a onepercentage-point increase in the unemployment rate is associated with a $0.79-4.5 \%$ increase in the suicide rate, although this review does not systematically compare effect sizes in different studies.

One reason behind our larger estimated effect size is that we use monthly panel data, adopt an event-study specification with time-varying estimates, and obtain the maximum monthly estimate in July 2020. Another possible reason is that the sharp employment shock under the COVID-19 crisis may have caused unusual shortterm impact on suicide and suicidal ideation, likely in interaction with other factors. There is also possibility that confounding upward bias causes such large estimates, although the addition of the eight covariates that may explain some regional variations of COVID-19 impacts does not change the estimates much.

In conclusion, our findings of association between the employment shock during the first wave of COVID-19 and suicide and safety net use implies that the increase in COVID-19-related unemployment has led to non-negligible increases in suicide and financial distress. At the same time, due to the limitations of our aggregated data and the scope of our research design, this paper cannot disentangle more precisely the interplay between unemployment, mental and financial distress, and safety net participation under the COVID-19 crisis and its causal mechanisms. These topics should be examined in future studies. 
medRxiv preprint doi: https://doi.org/10.1101/2020.11.16.20232850; this version posted November 24, 2021. The copyright holder for this preprint (which was not certified by peer review) is the author/funder, who has granted medRxiv a license to display the preprint in It is made available under a CC-BY-NC-ND 4.0 International license .

\section{References}

[1] Eguchi A, Nomura S, Gilmour S, Harada N, Sakamoto H, Ueda P, et al. Suicide by gender and 10-year age groups during the COVID-19 pandemic vs previous five years in Japan: an analysis of national vital statistics. Psychiatry Research. 2021:114173.

[2] Isumi A, Doi S, Yamaoka Y, Takahashi K, Fujiwara T. Do suicide rates in children and adolescents change during school closure in Japan? The acute effect of the first wave of COVID-19 pandemic on child and adolescent mental health. Child Abuse \& Neglect. 2020;110:104680.

[3] Sueki H, Ueda M. Short-term effect of the COVID-19 pandemic on suicidal ideation: A prospective cohort study. PsyArXiv. 2020.

[4] Ueda M, Stickley A, Sueki H, Matsubayashi T. Mental health status of the general population in Japan during the COVID-19 pandemic. Psychiatry and Clinical Neurosciences. 2020;74(9):505-506.

[5] Nagasu M, Muto K, Yamamoto I. Impacts of anxiety and socioeconomic factors on mental health in the early phases of the COVID-19 pandemic in the general population in Japan: A web-based survey. PloS One. 2021;16(3):e0247705.

[6] Nomura S, Kawashima T, Yoneoka D, Tanoue Y, Eguchi A, Gilmour S, et al. Trends in suicide in Japan by gender during the COVID-19 pandemic, up to September 2020. Psychiatry Research. 2021;295:113622.

[7] Pirkis J, John A, Shin S, DelPozo-Banos M, Arya V, Analuisa-Aguilar P, et al. Suicide trends in the early months of the COVID-19 pandemic: an interrupted time-series analysis of preliminary data from 21 countries. The Lancet Psychiatry. 2021.

[8] Sakamoto H, Ishikane M, Ghaznavi C, Ueda P. Assessment of suicide in Japan during the COVID-19 pandemic vs previous years. JAMA Network Open. 2021;4(2):e2037378-e2037378.

[9] Tanaka T, Okamoto S. Increase in suicide following an initial decline during the COVID-19 pandemic in Japan. Nature Human Behaviour. 2021;5(2):229-238.

[10] Ueda M, Nordström R, Matsubayashi T. Suicide and mental health during the COVID-19 pandemic in Japan. Journal of public health (Oxford, England). 2021.

[11] Adams-Prassl A, Boneva T, Golin M, Rauh C. Inequality in the impact of the coronavirus shock: Evidence from real time surveys. Journal of Public Economics. 2020;189:104245. 
medRxiv preprint doi: https://doi.org/10.1101/2020.11.16.20232850; this version posted November 24, 2021. The copyright holder for this preprint (which was not certified by peer review) is the author/funder, who has granted medRxiv a license to display the preprint in It is made available under a CC-BY-NC-ND 4.0 International license .

[12] Bitler M, Hoynes HW, Schanzenbach DW. The social safety net in the wake of COVID-19. Brookings Papers on Economic Activity. 2020;Summer:119-145.

[13] Chetty R, Friedman JN, Hendren N, Stepner M, the Opportunity Insights Team. The Economic impacts of COVID-19: Evidence from a new public database built using private sector data. Opportunity Insights Working Paper. 2020.

[14] Moffitt RA, Ziliak JP. COVID-19 and the US Safety Net. Fiscal Studies. 2020;41(3):515-548.

[15] Kikuchi S, Kitao S, Mikoshiba M. Who suffers from the COVID-19 shocks? Labor market heterogeneity and welfare consequences in Japan. Journal of the Japanese and International Economies. 2021;59:101117.

[16] Saloner B, Gollust SE, Planalp C, Blewett LA. Access and enrollment in safety net programs in the wake of COVID-19: A national cross-sectional survey. PloS One. 2020;15(10):e0240080.

[17] Kawohl W, Nordt C. COVID-19, unemployment, and suicide. The Lancet Psychiatry. 2020;7(5):389-390.

[18] Gunnell D, Appleby L, Arensman E, Hawton K, John A, Kapur N, et al. Suicide risk and prevention during the COVID-19 pandemic. The Lancet Psychiatry. 2020;7(6):468-471.

[19] Arthi V, Parman J. Disease, downturns, and wellbeing: Economic history and the long-run impacts of COVID-19. Explorations in Economic History. 2021;79:101381.

[20] Ruhm CJ. Are recessions good for your health? The Quarterly Journal of Economics. 2000;115(2):617-650.

[21] Neumayer E. Recessions lower (some) mortality rates:: evidence from Germany. Social Science \& Medicine. 2004;58(6):1037-1047.

[22] Kuroki M. Suicide and unemployment in Japan: evidence from municipal level suicide rates and age-specific suicide rates. The Journal of Socio-Economics. 2010;39(6):683-691.

[23] Chen J, Choi YJ, Sawada Y. How is suicide different in Japan? Japan and the World Economy. 2009;21(2):140-150.

[24] Chen J, Choi YJ, Mori K, Sawada Y, Sugano S. Socio-economic studies on suicide: A survey. Journal of Economic Surveys. 2012;26(2):271-306. 
medRxiv preprint doi: https://doi.org/10.1101/2020.11.16.20232850; this version posted November 24, 2021. The copyright holder for this preprint (which was not certified by peer review) is the author/funder, who has granted medRxiv a license to display the preprint in It is made available under a CC-BY-NC-ND 4.0 International license .

[25] Chen J, Choi YJ, Mori K, Sawada Y, Sugano S. An analysis of suicides in Japan, 1997-2007: Changes in incidence, persistence, and age profiles. Social Indicators Research. 2015;121(1):253-272.

[26] Ruhm CJ. Recessions, healthy no more? Journal of Health Economics. $2015 ; 42: 17-28$.

[27] Breuer C. Unemployment and suicide mortality: evidence from regional panel data in Europe. Health Economics. 2015;24(8):936-950.

[28] Matsubayashi T, Sekijima K, Ueda M. Government spending, recession, and suicide: evidence from Japan. BMC Public Health. 2020;20(1):1-8.

[29] Huikari S, Korhonen M. The impact of unemployment on well-being: evidence from the regional level suicide data in Finland. Social Indicators Research. 2016;128(3):1103-1119.

[30] Huikari S, Korhonen M. Unemployment, global economic crises and suicides: evidence from 21 OECD countries. Applied Economics. 2021;53(13):1540-1550.

[31] Frasquilho D, Matos MG, Salonna F, Guerreiro D, Storti CC, Gaspar T, et al. Mental health outcomes in times of economic recession: a systematic literature review. BMC Public Health. 2016;16(1):115.

[32] Bitler M, Hoynes H. The more things change, the more they stay the same? The safety net and poverty in the Great Recession. Journal of Labor Economics. 2016;34(S1):S403-S444.

[33] Ganong P, Liebman JB. The decline, rebound, and further rise in SNAP enrollment: Disentangling business cycle fluctuations and policy changes. American Economic Journal: Economic Policy. 2018;10(4):153-76.

[34] Bitler MP, Hoynes HW, Iselin J. Cyclicality of the US safety net: Evidence from the 2000s and implications for the COVID-19 crisis. National Tax Journal. 2020;73(3):759-779.

[35] Ando M, Furukawa C, Nakata D, Sumiya K. Fiscal responses to the COVID-19 crisis in Japan: the first six months. National Tax Journal. 2020;73(3):901-926.

[36] Kitazawa K. International comparison of unemployment compensation programs: focus on recipient ratio to unemployed workers. Japan Labor Review. 2015;12(2):124-144.

[37] Sakai T. Better policies for non-regular workers are still in progress (in Japanese). The Nikkei. 2021;February 2nd. 
medRxiv preprint doi: https://doi.org/10.1101/2020.11.16.20232850; this version posted November 24, 2021. The copyright holder for this preprint (which was not certified by peer review) is the author/funder, who has granted medRxiv a license to display the preprint in It is made available under a CC-BY-NC-ND 4.0 International license .

[38] Japan Times. Suicide spike in Japan shows mental health toll of COVID-19; October 9th, 2020. https://www.japantimes.co.jp/news/2020/10/09/ national/social-issues/suicide-mental-health-coronavirus. https: //www.japantimes.co.jp/news/2020/10/09/national/social-issues/ suicide-mental-health-coronavirus.

[39] Japan Times. Japan suicides rise as economic impact of coronavirus hits home; November 11th, 2020. https://www.japantimes.co.jp/news/2020/11/11/ national/japan-suicide-rise-coronavirus. https://www.japantimes . co.jp/news/2020/11/11/national/japan-suicide-rise-coronavirus.

[40] Solon G, Haider SJ, Wooldridge JM. What are we weighting for? Journal of Human resources. 2015;50(2):301-316.

[41] Google LLC. Google COVID-19 Community Mobility Reports; 2021. https: //www.google.com/covid19/mobility/Accessed:<25July2021>.

[42] Kisho H, Hiroyuki K, Ryo M, Michio S, Satoshi T. The Heterogeneous Effects of COVID-19 on Labor Markets: People's Movement and Non-Pharmaceutical Interventions. Research Institute of Economy, Trade and Industry (RIETI); 2021. 21045. Available from: https://ideas.repec.org/p/eti/dpaper/21045. html.

[43] Hoshi K, Kasahara H, Makioka R, Suzuki M, Tanaka S. Trade-off between job losses and the spread of COVID-19 in Japan. The Japanese Economic Review. 2021:1-34.

[44] Ministry of Health, Labour and Welfare. Visualizing the data: information on COVID-19 infections; 2021. Visualizingthedata: informationonCOVID-19infections".https://covid19.mhlw.go.jp/ Accessed: $<25 \mathrm{July} 2021>$. 
medRxiv preprint doi: https://doi.org/10.1101/2020.11.16.20232850; this version posted November 24 , 2021. The copyright holder for this preprint (which was not certified by peer review) is the author/funder, who has granted medRxiv a license to display the preprint in

It is made available under a CC-BY-NC-ND 4.0 International license .

\section{Appendices}

\section{A Background information}

Figure A.1: Confirmed cases/deaths and government responses in Jan.-Jun. 2020

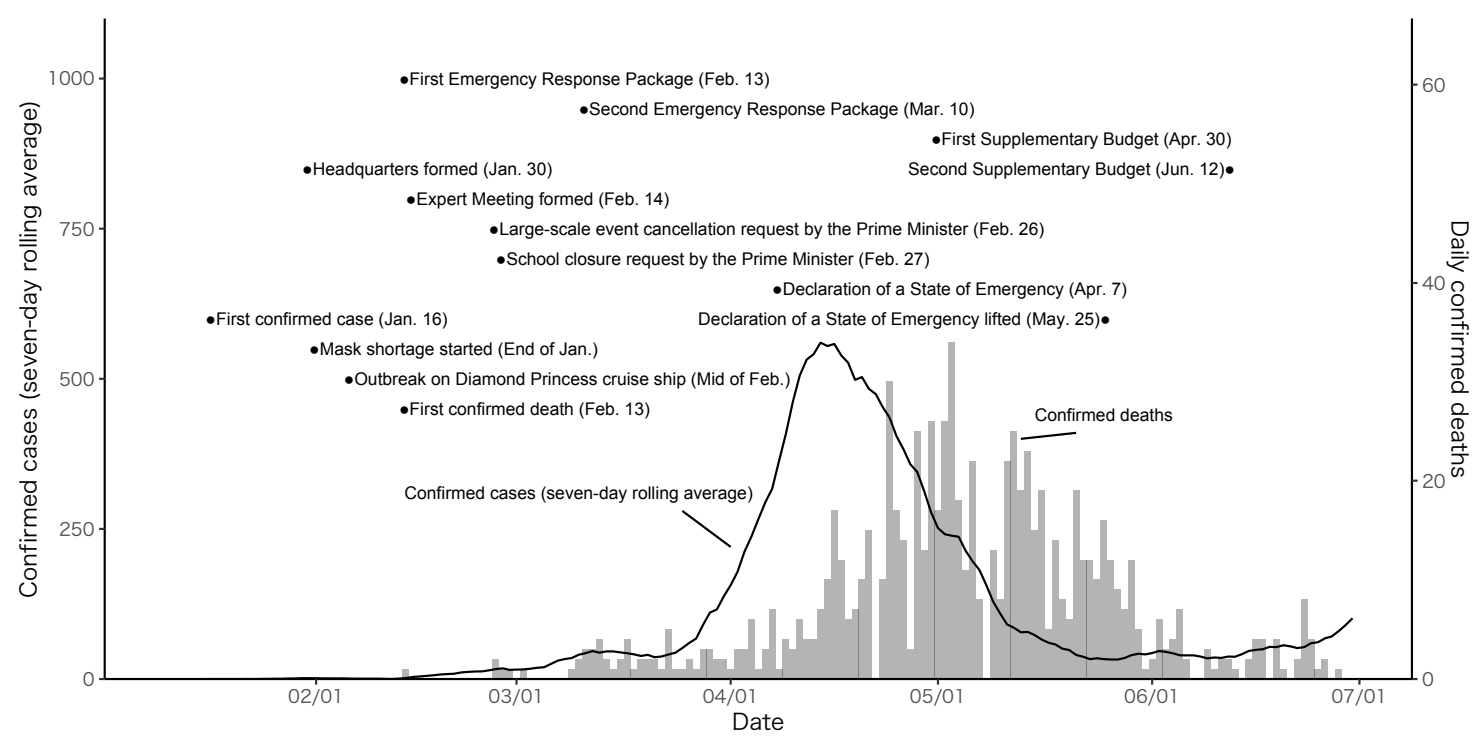

Notes: Due to the lack of continuity in the cumulative number of deaths in the original data, the number of deaths on April 22 and May 8 are treated as zero. In addition, Saitama Prefecture announced on June 19 that "the number of confirmed deaths increased by 13 as a result of reviewing the method of recording confirmed deaths based on the criteria provided by the central government" and this amount was added to the cumulative confirmed deaths on the same day in the original data. We however subtracted this amount from the statistics.

Source: The website of MHLW https://www.mhlw.go.jp/stf/covid-19/open-data.html). This graph is based on a similar graph in [35]. 
medRxiv preprint doi: https://doi.org/10.1101/2020.11.16.20232850; this version posted November 24,2021 . The copyright holder for this preprint (which was not certified by peer review) is the author/funder, who has granted medRxiv a license to display the preprint in

It is made available under a CC-BY-NC-ND 4.0 International license .

Figure A.2: Mobility during and after the first COVID-19 state of emergency

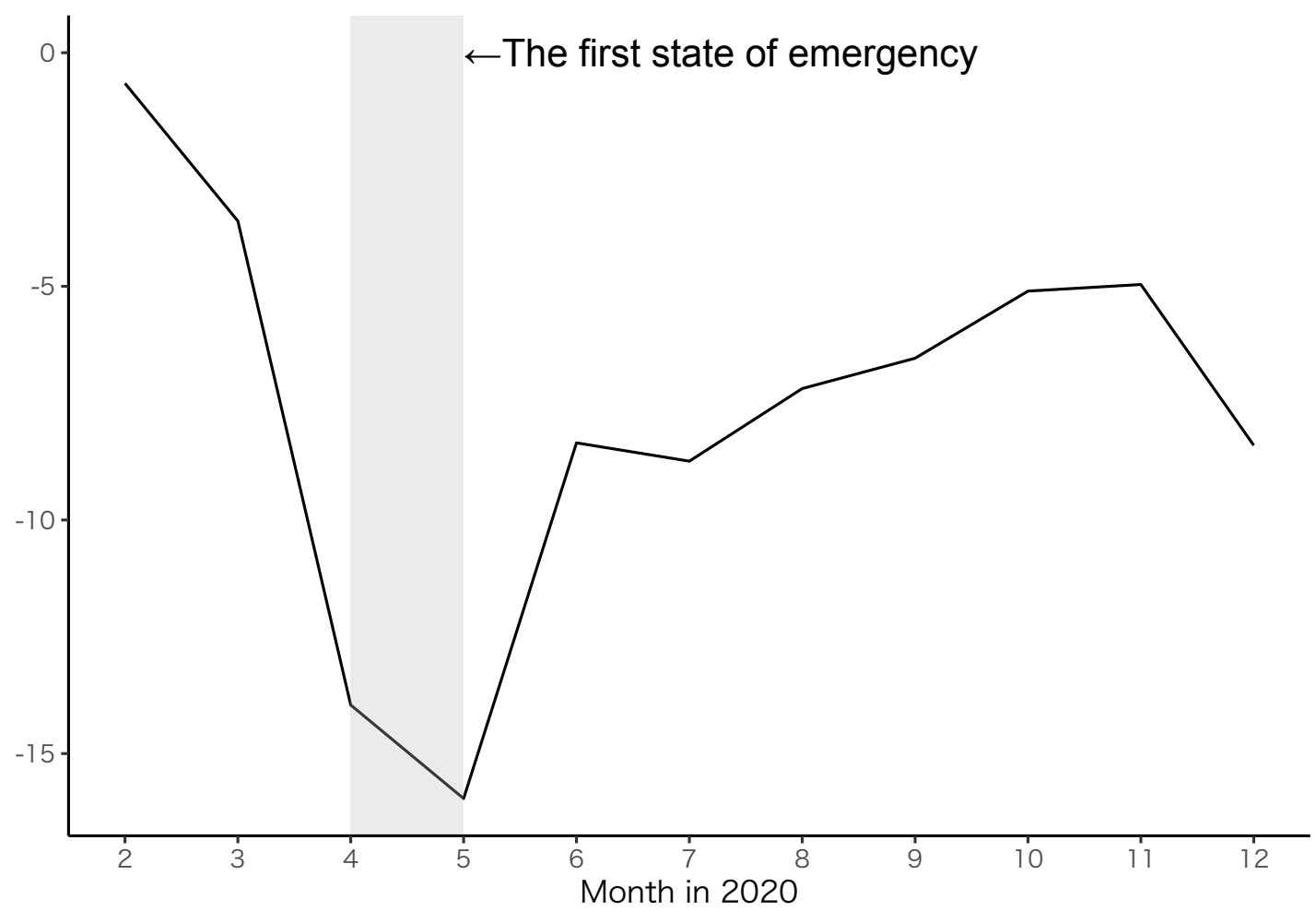

Notes: Figure shows the percentage change in the number of visitors to (or time spent in) different locations compared to the baseline number computed from January 3rd and February 6th, 2020. Google provides data on people's visits to six categories of places. We calculated the monthly average values of Google Mobility indicators, following the definition of [42] and [43]. Our Google Mobility index is created by taking the average of four mobility measures ("Grocery and pharmacy', "Retail and recreation", "Transit stations'). See Tables 1 and A.2 for more details about these variables. A gray area indicates the period of the first COVID-19 state of emergency.

Source: Google COVID-19 Community Mobility Reports [41] 
medRxiv preprint doi: https://doi.org/10.1101/2020.11.16.20232850; this version posted November 24, 2021. The copyright holder for this preprint (which was not certified by peer review) is the author/funder, who has granted medRxiv a license to display the preprint in

It is made available under a CC-BY-NC-ND 4.0 International license .

Table A.1: Description of the three tiers of safety net programs

\begin{tabular}{|c|c|c|c|}
\hline Tier & Safety net program & Eligibile person/household & Amount per recipeient and duration \\
\hline First & $\begin{array}{l}\text { Unemployment benefits: } \\
\text { Unemployment insurance for the } \\
\text { unemployed }\end{array}$ & $\begin{array}{l}\text { Unemployed who are registered as } \\
\text { jobs seekers at their local public } \\
\text { employment security offices and } \\
\text { who have worked full-time for } 12 \\
\text { months or more in the previous } \\
\text { two years (basic benefit) }\end{array}$ & $\begin{array}{l}\text { Amount (basic benefit) } \\
50 \%-80 \% \text { of daily wages, but a maximum } \\
\text { amount per day is set, as follows, } \\
\text { depending on the age of recipients: } \\
6,815 \text { JPY ( } 62 \text { USD) for age up to } 29 \\
7,570 \text { JPY (69 USD) for age } 30-44 ; \\
8,330 \text { JPY ( } 76 \text { USD) for age } 45-59 ; \\
7,150 \text { JPY ( } 65 \text { USD) for age } 60-64 \text {. } \\
\text { Duration (basic benefit) } \\
\text { Payment duration also differs by age and } \\
\text { period of insurance enrollment }\end{array}$ \\
\hline Second & $\begin{array}{l}\text { Emergency Small Amount Funds: } \\
\text { Means-tested loan programs }\end{array}$ & $\begin{array}{l}\text { Households facing a decrease in } \\
\text { income due to temporary stoppage } \\
\text { of work, etc }\end{array}$ & $\begin{array}{l}\text { Amount } \\
\text { Up to } 100,000-200,000 \text { JPY } \\
\text { (909-1,818 USD) } \\
\text { Duration } \\
\text { Available only once }\end{array}$ \\
\hline Second & $\begin{array}{l}\text { General Support Funds: } \\
\text { Means-tested loan programs }\end{array}$ & $\begin{array}{l}\text { Households suffering financially } \\
\text { because of reduced income or } \\
\text { unemployment }\end{array}$ & $\begin{array}{l}\text { Amount } \\
\text { Up to } 150,000-200,000 \text { JPY } \\
\text { (1,364-1,818 USD) per month } \\
\text { Duration } \\
\text { An upper limit of 3-9 months }\end{array}$ \\
\hline Second & $\begin{array}{l}\text { Housing Security Benefit: } \\
\text { Means-tested housing benefit programs }\end{array}$ & $\begin{array}{l}\text { Households at risk of losing their } \\
\text { current housing due to financial } \\
\text { distress, unemployment, etc. }\end{array}$ & $\begin{array}{l}\text { Amount } \\
\text { Maximum ammount per month differ by } \\
\text { household type and region. } \\
\text { For example, in a Tokyo metropolitan area, } \\
\text { typical maximum ammouts are: } \\
\text { Single: } 53,700 \text { JPY ( } 488 \text { USD) } \\
\text { Two persons: } 64,000 \text { JPY (582 USD) } \\
\text { Three persons: } 69,800 \text { JPY ( } 635 \text { USD) } \\
\text { Duration } \\
\text { An upper limit of } 3-9 \text { months }\end{array}$ \\
\hline Third & $\begin{array}{l}\text { Public assistance: } \\
\text { Means-tested social assistance benefit }\end{array}$ & $\begin{array}{l}\text { Households anable to maintain a } \\
\text { minimum standard of living even } \\
\text { when using all means at their } \\
\text { disposal }\end{array}$ & $\begin{array}{l}\text { Amount } \\
\text { Assistance payment differs by household } \\
\text { type and region, but in principle } \\
\text { determined by the following formula: } \\
\text { minimum standard of living - income } \\
\text { Duration } \\
\text { No explicit limit }\end{array}$ \\
\hline
\end{tabular}

Notes: All information is based on the institutional settings in September 2020.

Source: Authors' description based on official documents. 
Table A.2: Variable definitions and data sources

\begin{tabular}{|c|c|c|}
\hline Variable & Definition & Data source \\
\hline $\begin{array}{l}\text { Employment } \\
\text { Unemployment rate (\%) } \\
\text { "Full-time" unemployment rate (\%) } \\
\text { Labor force participation rate (\%) } \\
\text { Employment rate (\%) } \\
\text { Jobs-to-applicants ratio } \\
\text { Suicide and safety net (per 100k) } \\
\text { Suicide rate } \\
\text { Unemployment benefit recipients } \\
\text { Emergency Small Amount Funds } \\
\text { General Support Funds } \\
\text { Housing Security Benefit } \\
\text { public Assistance recipients } \\
\text { Public assistance recipient households } \\
\text { Covariates } \\
\text { COVID-19 cumulative infection rate } \\
\text { COVID-19 cumulative death rate } \\
\text { Google Mobility index } \\
\text { Population density } \\
\text { Ratio of employees (secondary sector) } \\
\text { Ratio of employees (service sector) } \\
\text { Elderly dependency rate (\%) } \\
\text { Total population }\end{array}$ & $\begin{array}{l}\text { Total unemployed population/Labor force } \\
\text { Registered "Full-time" job seekers/Labor force } \\
\text { Labor force/Population aged 15+ } \\
\text { Employed/Population aged 15+ } \\
\text { Registered job offers/Registered unemployed } \\
\text { Suicides/Population (total or by gender) } \\
\text { Benefit recipients/Population (total or by gender) } \\
\text { Accepted applications/Population } \\
\text { Accepted applications/Population } \\
\text { Accepted applications/Population } \\
\text { Recipients/Population } \\
\text { Recipient households/Population } \\
\text { Cumulative COVID-19 infections /Pop. (June 2020) } \\
\text { Cumulative COVID-19 deaths/Pop. (June 2020) } \\
\text { Average of four mobility measures (May 2020) } \\
\text { Population/Inhabitable area } \\
\text { Employees in the secondary industry/Employees } \\
\text { Employees in the tertiary industry/Employees } \\
\text { Population aged 65+/Population aged 15-64 } \\
\text { Total population }\end{array}$ & $\begin{array}{l}\text { Labour Force Survey (LFS) } \\
\text { General Employment Placement Status \& LFS } \\
\text { Labour Force Survey (LFS) } \\
\text { Labour Force Survey (LFS) } \\
\text { General Employment Placement Status } \\
\text { Statistics of Suicide } \\
\text { Monthly Report of Unemployment Insurance } \\
\text { Provided by the central government } \\
\text { Provided by the central government } \\
\text { Provided by the central government } \\
\text { National Survey on Public Assistance Recipients } \\
\text { National Survey on Public assistance Recipients } \\
\text { MHLW[44] } \\
\text { MHLW[44] } \\
\text { Google LLC } \\
\text { Census \& Census of Agriculture and Forestry } \\
\text { Census } \\
\text { Census } \\
\text { Census } \\
\text { Census }\end{array}$ \\
\hline
\end{tabular}

Notes: For the employment rate, labor force participation rate, unemployment rate, and job-to-applicants ratio in Figure 1, seasonally adjusted data are used. For the monthly data of the unemployment rates that are used for the construction of the employment shocks based on equation (1), the data are not seasonally adjusted. For suicide rates and all the variables of safety net programs, nation-level data in Figure 1 and monthly-level data in Figure 2 and in Table 1 are based on raw data that are not seasonally adjusted. Prefecture-level aggregated suicide statistics based on residential addresses are also available, but we do not use these data due to the large number of missing values. In this paper we use the suicide statistics that were updated in December 2020. Some monthly total suicide numbers are updated in the original police statistics but not in the Statistics of Suicide by MHLW, but we use the latter data because it also provides gender-based suicide statistics. Note that estimation results for total suicide rates do not change much when we use the updated original police statistics. 
medRxiv preprint doi: https://doi.org/10.1101/2020.11.16.20232850; this version posted November 24 , 2021. The copyright holder for this preprint (which was not certified by peer review) is the author/funder, who has granted medRxiv a license to display the preprint in It is made available under a CC-BY-NC-ND 4.0 International license .

Table A.3: Suicides in 2019 and 2020 by age and occupation

\begin{tabular}{|c|c|c|c|c|c|c|c|}
\hline \multirow{2}{*}{$\frac{\text { Sex }}{\text { Year }}$} & \multicolumn{3}{|c|}{ Female } & \multicolumn{3}{|c|}{ Male } & \multirow{2}{*}{$\frac{\text { Total }}{2020-2019}$} \\
\hline & 2019 & 2020 & $2020-2019$ & 2019 & 2020 & $2020-2019$ & \\
\hline Total & 6091 & 7026 & 935 & 14078 & 14055 & -23 & 912 \\
\hline \multicolumn{8}{|l|}{ By age } \\
\hline Age $<20$ & 216 & 311 & 95 & 443 & 466 & 23 & 118 \\
\hline $20-29$ & 634 & 837 & 203 & 1483 & 1684 & 201 & 404 \\
\hline $30-39$ & 648 & 764 & 116 & 1878 & 1846 & -32 & 84 \\
\hline $40-49$ & 915 & 1102 & 187 & 2511 & 2466 & -45 & 142 \\
\hline $50-59$ & 938 & 1054 & 116 & 2497 & 2371 & -126 & -10 \\
\hline $60-69$ & 857 & 936 & 79 & 2045 & 1859 & -186 & -107 \\
\hline $70-79$ & 1035 & 1114 & 79 & 1882 & 1912 & 30 & 109 \\
\hline Age $>80$ & 840 & 900 & 60 & 1294 & 1405 & 111 & 171 \\
\hline Unknown & 8 & 8 & 0 & 45 & 46 & 1 & 1 \\
\hline \multicolumn{8}{|l|}{ By occupation } \\
\hline Self-employed & 151 & 172 & 21 & 1259 & 1094 & -165 & -144 \\
\hline Employed & 1145 & 1534 & 389 & 5057 & 5208 & 151 & 540 \\
\hline Non-employed & 4740 & 5263 & 523 & 7493 & 7494 & 1 & 524 \\
\hline Unknown & 55 & 57 & 2 & 269 & 259 & -10 & -8 \\
\hline
\end{tabular}

Notes: The numbers of suicides are based on dates suicides were found. The columns "2020-2019" show differences between 2019 and 2020.

Source: Statistics of Suicide (Ministry of Health, Labour, and Welfare) 
medRxiv preprint doi: https://doi.org/10.1101/2020.11.16.20232850; this version posted November 24, 2021. The copyright holder for this preprint (which was not certified by peer review) is the author/funder, who has granted medRxiv a license to display the preprint in

It is made available under a CC-BY-NC-ND 4.0 International license .

\section{B Robustness checks: weighting and linear trends}

Figure B.1: Additional DID estimates for suicides

(a) Total

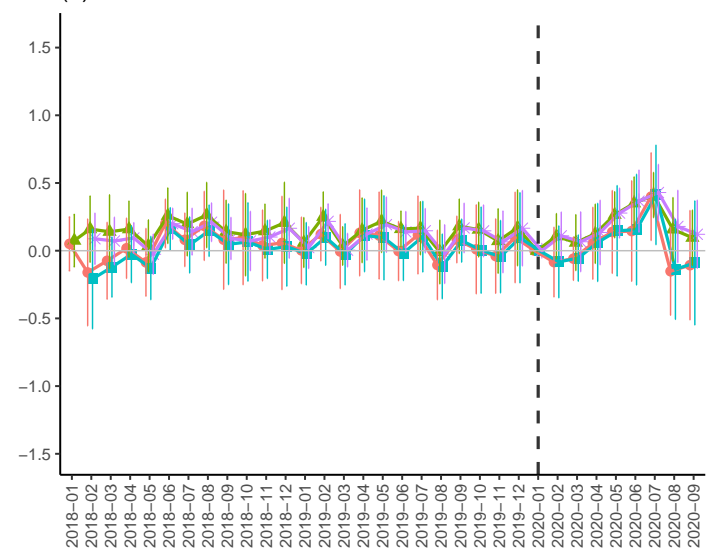

(c) Female

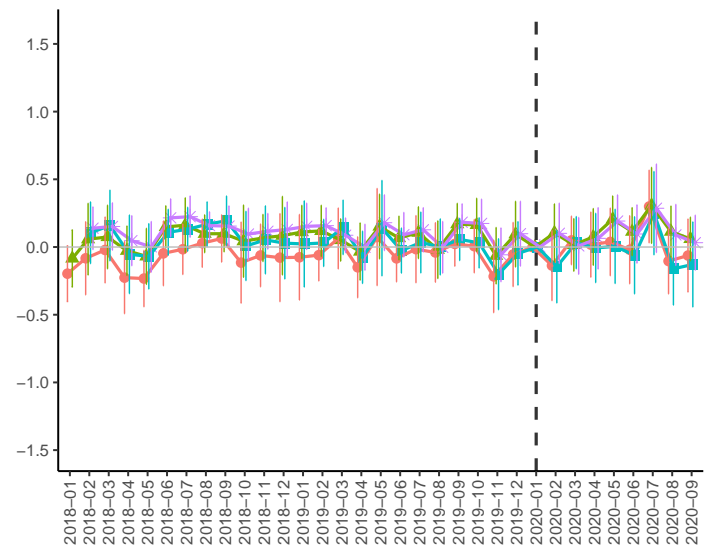

(e) Male

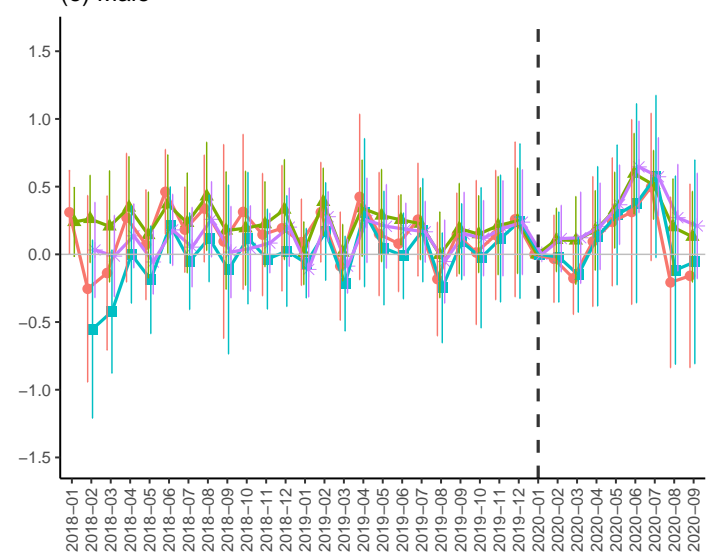

(b) Total, with covaraites

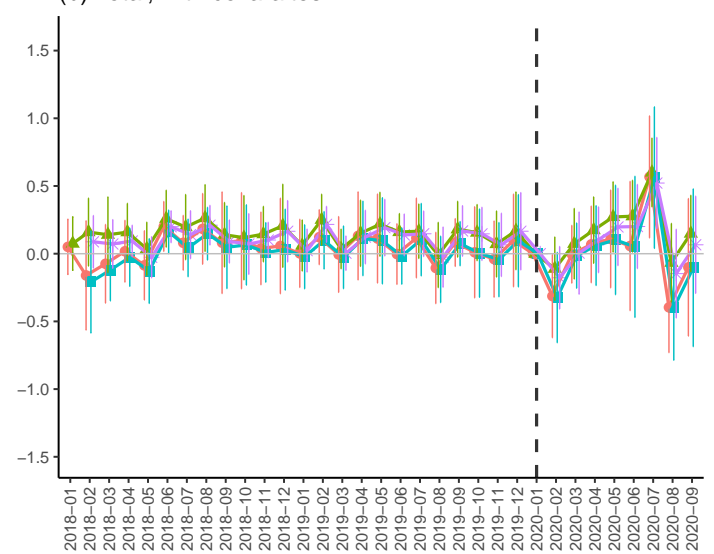

(d) Female, with covaraites

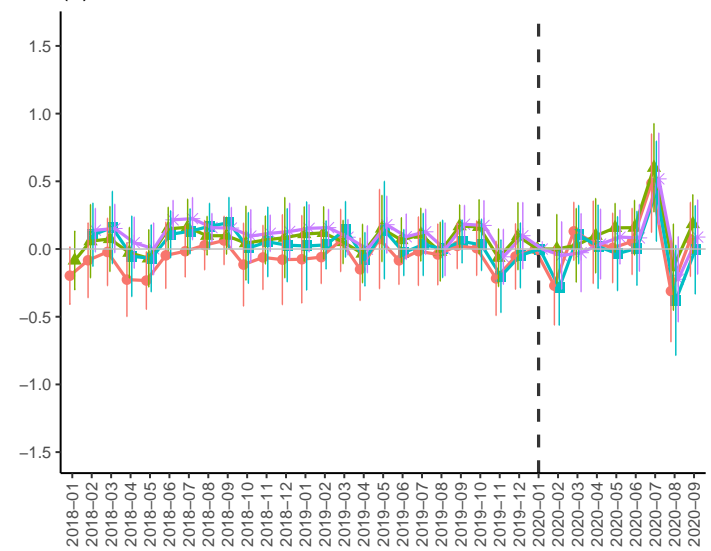

(f) Male, with covaraites

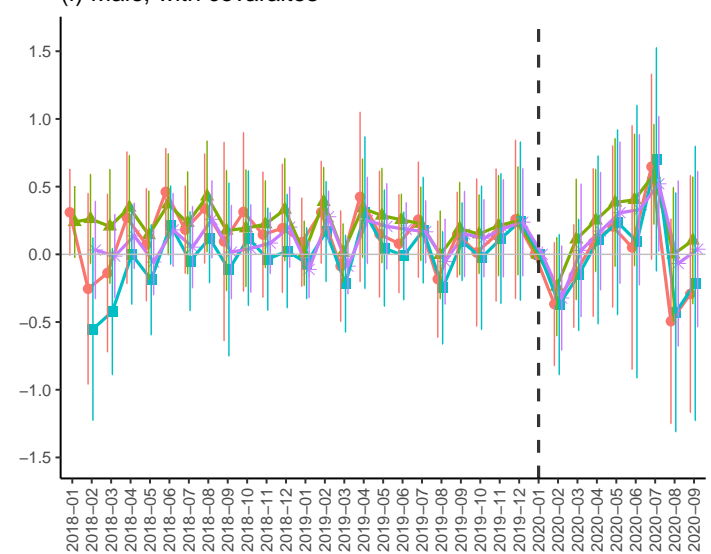

$*$ OLS without trends $*$ WLS without trends $*$ OLS with trends $*$ WLS with trends

Notes: See the notes on Figure 3 for descriptions of plots and confidence intervals. WLS estimation is weighted by prefecture population size. Estimation "with trends" incorporates individual (i.e., prefecture) linear trends and estimation "without trends" does not include these linear trend terms. Estimation using "WLS with trends" is identical to the baseline estimation in Figure 3. 
medRxiv preprint doi: https://doi.org/10.1101/2020.11.16.20232850; this version posted November 24, 2021. The copyright holder for this preprint (which was not certified by peer review) is the author/funder, who has granted medRxiv a license to display the preprint in

perpetuity.
It is made available under a CC-BY-NC-ND 4.0 International license .

Figure B.2: Additional DID estimates for unemployment benefit recipients

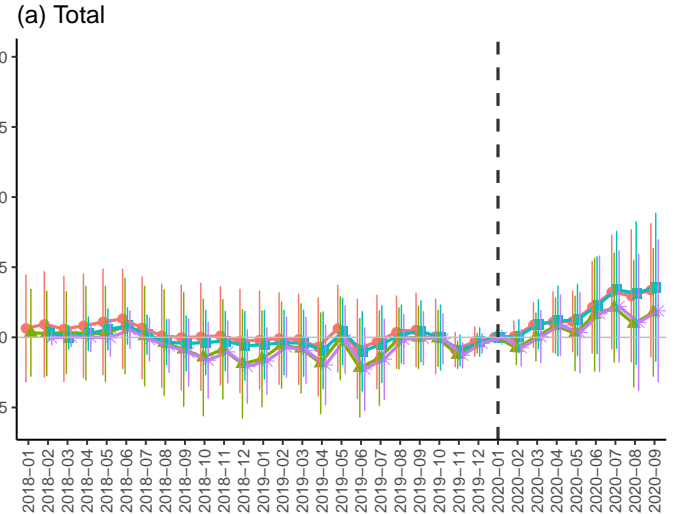

(c) Female

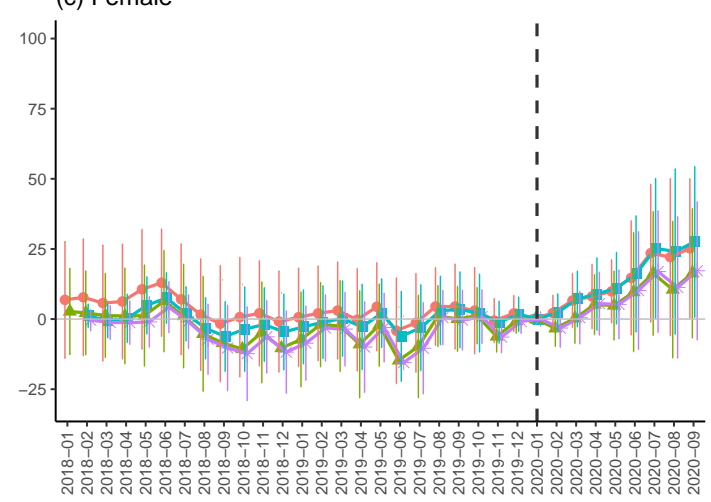

(e) Male

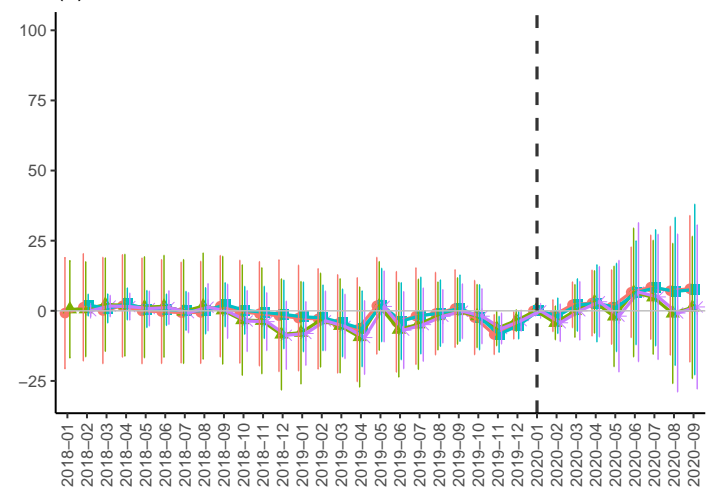

(b) Total, with covaraites

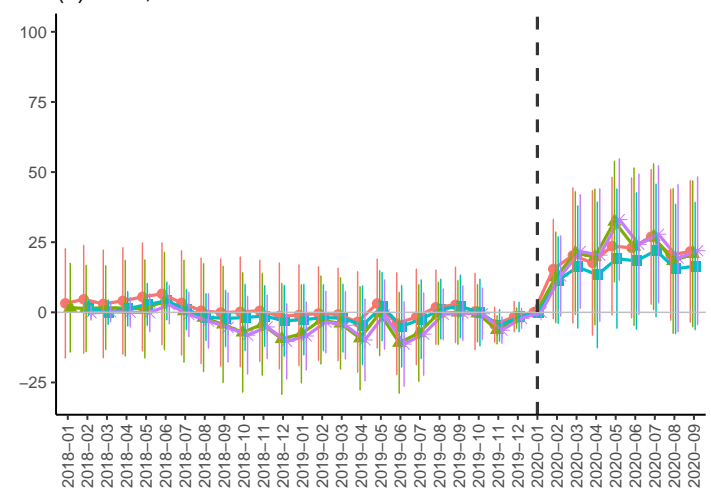

(d) Female, with covaraites

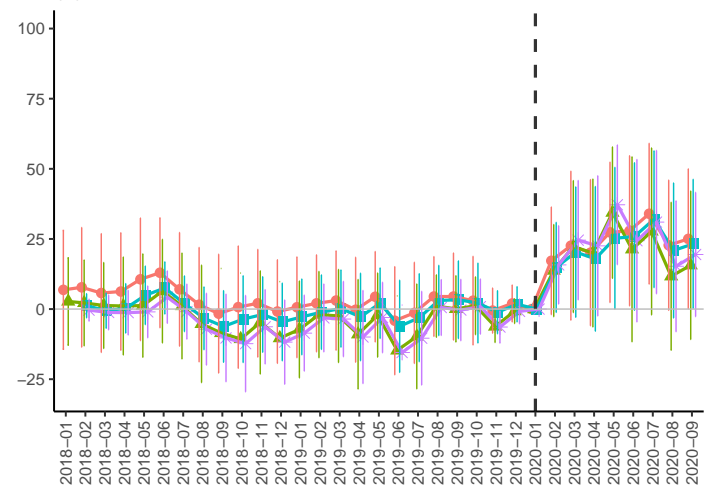

(f) Male, with covaraites

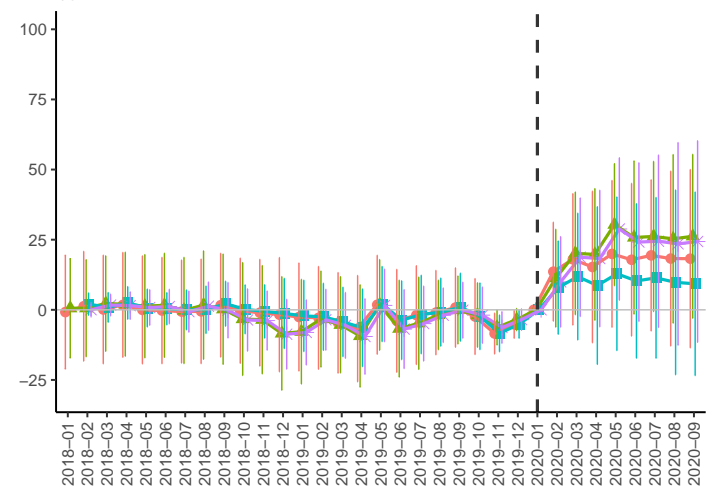

$*$ OLS without trends $=$ WLS without trends $=$ OLS with trends $*$ WLS with trends

Notes: See the notes on Figure 4 for descriptions of plots and confidence intervals. WLS estimation is weighted by prefecture population size. Estimation "with trends" incorporates individual (i.e., prefecture) linear trends and estimation "without trends" does not include these linear trend terms. Estimation using "WLS with trends" is identical with the baseline estimation in Figure 4. 
medRxiv preprint doi: https://doi.org/10.1101/2020.11.16.20232850; this version posted November 24, 2021. The copyright holder for this preprint (which was not certified by peer review) is the author/funder, who has granted medRxiv a license to display the preprint in

It is made available under a CC-BY-NC-ND 4.0 International license.

Figure B.3: Additional DID estimates for second-tier safety net

(a) Emergency Small Amount Funds

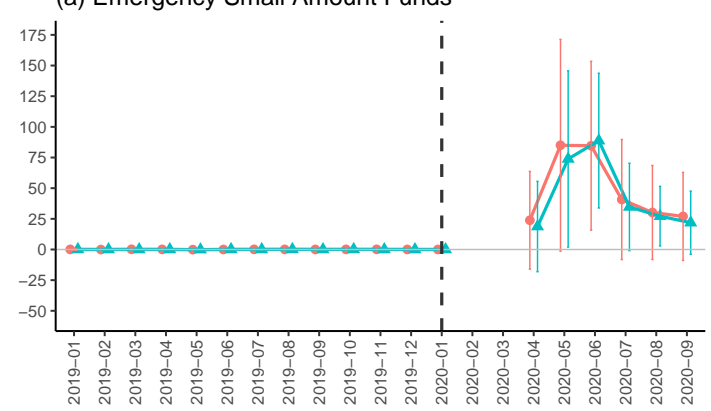

(c) General Support Funds

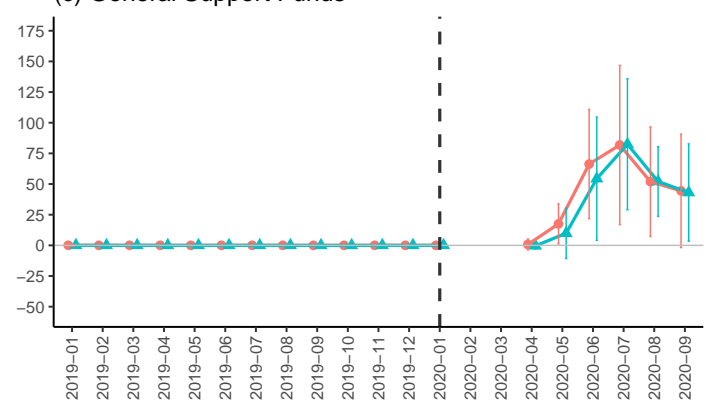

(e) Housing Security Benefit

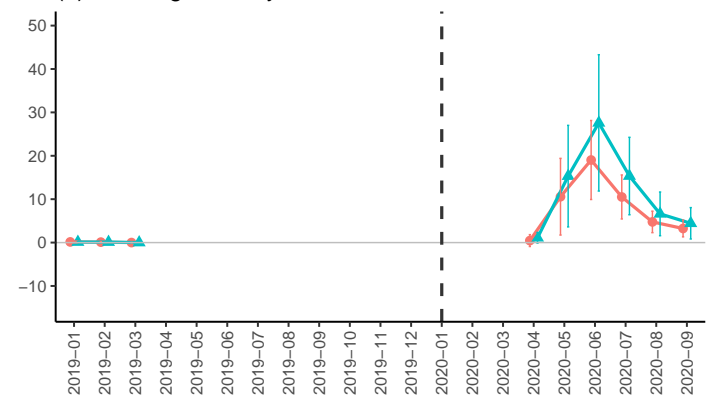

(b) Emergency Small Amount Funds, with covariates

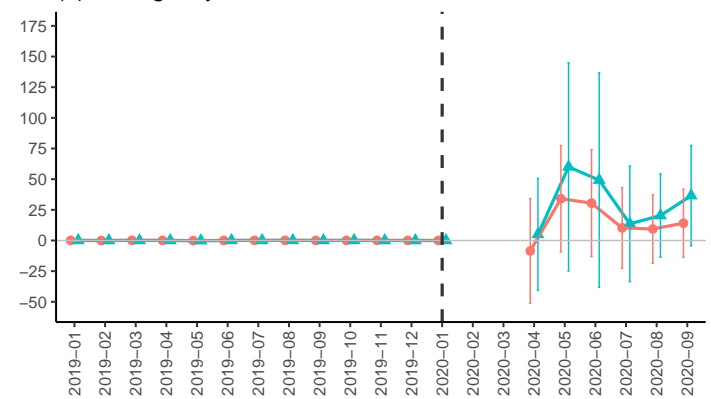

(d) General Support Funds, with covariates

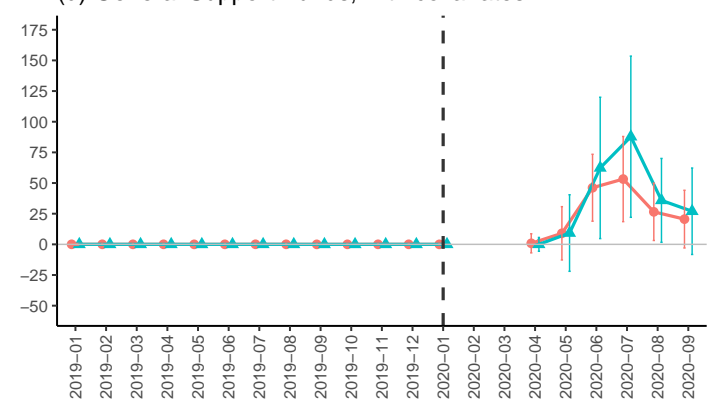

(f) Housing Security Benefit, with covariates

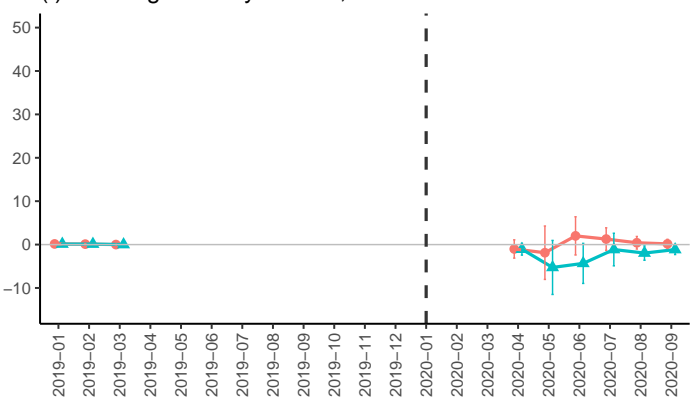

$-\mathrm{OLS}=\mathrm{WLS}$

Notes: See the notes on Figure 5 for descriptions of plots and confidence intervals. WLS estimation is weighted by prefecture population size and is identical with the baseline estimation in Figure 5. 
medRxiv preprint doi: https://doi.org/10.1101/2020.11.16.20232850; this version posted November 24, 2021. The copyright holder for this preprint (which was not certified by peer review) is the author/funder, who has granted medRxiv a license to display the preprint in

perpetuity.
It is made available under a CC-BY-NC-ND 4.0 International license .

Figure B.4: Additional DID estimates for public assistance

(a) Recipients

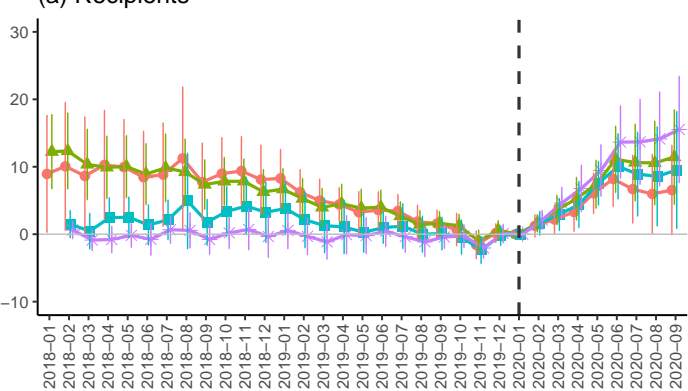

(c) Recipient households

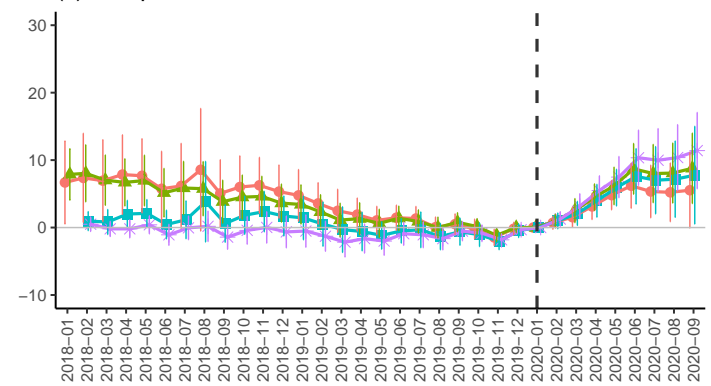

(b) Recipients, with covariates

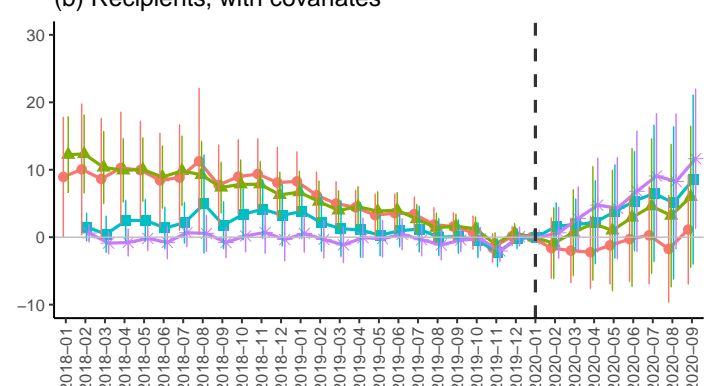

(d) Recipient households, with covariates

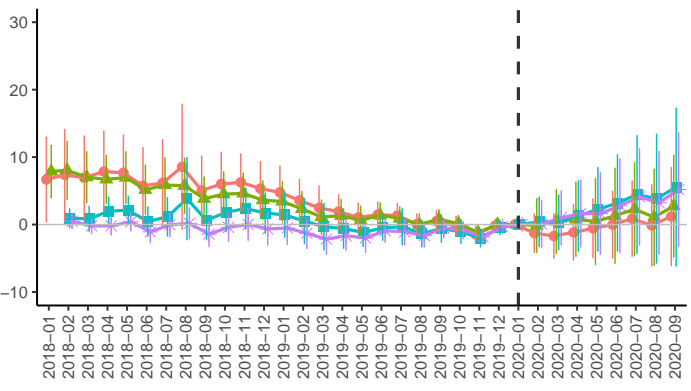

$*$ OLS without trends $\neq$ WLS without trends $=$ OLS with trends $*$ WLS with trends

Notes: See the notes on Figure 6 for descriptions of plots and confidence intervals. WLS estimation is weighted by prefecture population size. Estimation "with trends" incorporates individual (i.e., prefecture) linear trends and estimation "without trends" does not include these linear trend terms. Estimation using "WLS with trends" is identical to the baseline estimation in Figure 6. 
medRxiv preprint doi: https://doi.org/10.1101/2020.11.16.20232850; this version posted November 24 , 2021. The copyright holder for this preprint (which was not certified by peer review) is the author/funder, who has granted medRxiv a license to display the preprint in

It is made available under a CC-BY-NC-ND 4.0 International license .

\section{Robustness checks: a different reference period}

Table C.1: Estimation results for suicide rates

\begin{tabular}{|c|c|c|c|c|c|c|}
\hline & \multicolumn{2}{|c|}{ Total } & \multicolumn{2}{|c|}{ Female } & \multicolumn{2}{|c|}{ Male } \\
\hline & (1) & $(2)$ & (3) & $(4)$ & $(5)$ & (6) \\
\hline \multirow[t]{2}{*}{ Feb. 2020} & 0.110 & -0.007 & 0.101 & 0.022 & 0.117 & -0.038 \\
\hline & $(0.104)$ & $(0.074)$ & $(0.132)$ & (0.097) & & $(0.123)$ \\
\hline \multirow[t]{2}{*}{ Mar. 2020} & 0.066 & -0.051 & 0.008 & -0.068 & 0.123 & -0.037 \\
\hline & $(0.131)$ & $(0.086)$ & $(0.125)$ & $(0.086)$ & $(0.201)$ & $(0.165)$ \\
\hline \multirow[t]{2}{*}{ Apr. 2020} & 0.134 & 0.016 & 0.064 & -0.011 & 0.207 & 0.043 \\
\hline & $(0.142)$ & $(0.078)$ & $(0.135)$ & $(0.089)$ & $(0.190)$ & $(0.118)$ \\
\hline \multirow[t]{2}{*}{ May. 2020} & 0.278 & 0.158 & 0.192 & 0.119 & 0.366 & 0.198 \\
\hline & $(0.109)$ & $(0.104)$ & $(0.115)$ & $(0.093)$ & $(0.175)$ & $(0.176)$ \\
\hline \multirow[t]{2}{*}{ Jun. 2020} & 0.366 & 0.245 & 0.096 & 0.025 & 0.646 & 0.474 \\
\hline & $(0.136)$ & $(0.074)$ & $(0.128)$ & $(0.063)$ & $(0.201)$ & $(0.134)$ \\
\hline \multirow[t]{2}{*}{ Jul. 2020} & 0.430 & 0.308 & 0.286 & 0.217 & 0.573 & 0.396 \\
\hline & $(0.123)$ & $(0.063)$ & $(0.194)$ & $(0.124)$ & $(0.172)$ & $(0.152)$ \\
\hline \multirow[t]{2}{*}{ Aug. 2020} & 0.179 & 0.056 & 0.089 & 0.022 & 0.270 & 0.090 \\
\hline & $(0.158)$ & $(0.119)$ & $(0.134)$ & $(0.089)$ & $(0.234)$ & $(0.193)$ \\
\hline \multirow[t]{2}{*}{ Sep. 2020} & 0.121 & -0.003 & 0.032 & -0.033 & 0.210 & 0.024 \\
\hline & $(0.150)$ & $(0.091)$ & $(0.121)$ & $(0.079)$ & $(0.232)$ & $(0.155)$ \\
\hline Sample size & 1551 & 1551 & 1551 & 1551 & 1551 & 1551 \\
\hline R2 Adj. & 0.379 & 0.379 & 0.175 & 0.176 & 0.373 & 0.376 \\
\hline Ref. month & Jan.2020 & $\leq$ Jan.2020 & Jan.2020 & $\leq$ Jan.2020 & Jan.2020 & $\leq$ Jan.2020 \\
\hline
\end{tabular}

Notes: Columns (1), (3), and (5) present baseline WLS estimates shown in the lefthand side of Figure 3. Columns (2), (4), and (6) present WLS estimates based on the model (3), weighted by prefecture population size. The treatment variable is the COVID-19-induced employment shock, which is calculated as equation (1). Robust standard errors are clustered at the prefecture level. 
Table C.2: Estimation results for suicide rates, with covariates

\begin{tabular}{|c|c|c|c|c|c|c|}
\hline & \multicolumn{2}{|c|}{ Total } & \multicolumn{2}{|c|}{ Female } & \multicolumn{2}{|c|}{ Male } \\
\hline & (1) & $(2)$ & $(3)$ & (4) & $(5)$ & (6) \\
\hline Feb. 2020 & $\begin{array}{l}-0.178 \\
(0.137)\end{array}$ & $\begin{array}{c}-0.294 \\
(0.138)\end{array}$ & $\begin{array}{l}-0.047 \\
(0.148)\end{array}$ & $\begin{array}{c}-0.126 \\
(0.142)\end{array}$ & $\begin{array}{c}-0.323 \\
(0.229)\end{array}$ & $\begin{array}{l}-0.478 \\
(0.238)\end{array}$ \\
\hline Mar. 2020 & $\begin{array}{c}0.004 \\
(0.180)\end{array}$ & $\begin{array}{c}-0.113 \\
(0.162)\end{array}$ & $\begin{array}{l}-0.027 \\
(0.172)\end{array}$ & $\begin{array}{l}-0.104 \\
(0.138)\end{array}$ & $\begin{array}{c}0.029 \\
(0.292)\end{array}$ & $\begin{array}{l}-0.130 \\
(0.289)\end{array}$ \\
\hline Apr. 2020 & $\begin{array}{c}0.103 \\
(0.144)\end{array}$ & $\begin{array}{l}-0.016 \\
(0.106)\end{array}$ & $\begin{array}{c}0.036 \\
(0.153)\end{array}$ & $\begin{array}{l}-0.039 \\
(0.140)\end{array}$ & $\begin{array}{c}0.172 \\
(0.258)\end{array}$ & $\begin{array}{c}0.008 \\
(0.204)\end{array}$ \\
\hline May. 2020 & $\begin{array}{c}0.198 \\
(0.170)\end{array}$ & $\begin{array}{c}0.078 \\
(0.165)\end{array}$ & & $\begin{array}{c}0.015 \\
(0.118)\end{array}$ & $\begin{array}{c}0.308 \\
(0.311)\end{array}$ & $\begin{array}{c}0.140 \\
(0.308)\end{array}$ \\
\hline Jun. 2020 & $\begin{array}{c}0.201 \\
(0.185)\end{array}$ & $\begin{array}{c}0.080 \\
(0.140)\end{array}$ & $\begin{array}{c}0.082 \\
(0.147)\end{array}$ & $\begin{array}{c}0.011 \\
(0.118)\end{array}$ & $\begin{array}{c}0.329 \\
(0.330)\end{array}$ & $\begin{array}{c}0.157 \\
(0.267)\end{array}$ \\
\hline Jul. 2020 & $\begin{array}{c}0.522 \\
(0.200)\end{array}$ & $\begin{array}{c}0.400 \\
(0.148)\end{array}$ & $\begin{array}{c}0.518 \\
(0.201)\end{array}$ & $\begin{array}{c}0.449 \\
(0.138)\end{array}$ & $\begin{array}{c}0.521 \\
(0.296)\end{array}$ & $\begin{array}{c}0.344 \\
(0.249)\end{array}$ \\
\hline Aug. 2020 & $\begin{array}{c}-0.147 \\
(0.195)\end{array}$ & $\begin{array}{l}-0.270 \\
(0.165)\end{array}$ & $\begin{array}{l}-0.224 \\
(0.187)\end{array}$ & $\begin{array}{c}-0.291 \\
(0.177)\end{array}$ & $\begin{array}{l}-0.068 \\
(0.363)\end{array}$ & $\begin{array}{l}-0.248 \\
(0.317)\end{array}$ \\
\hline Sep. 2020 & $\begin{array}{c}0.066 \\
(0.214)\end{array}$ & $\begin{array}{l}-0.058 \\
(0.168)\end{array}$ & $\begin{array}{c}0.088 \\
(0.163)\end{array}$ & $\begin{array}{c}0.023 \\
(0.131)\end{array}$ & $\begin{array}{c}0.038 \\
(0.342)\end{array}$ & $\begin{array}{l}-0.147 \\
(0.277)\end{array}$ \\
\hline Sample size & 1551 & 1551 & 1551 & 1551 & 1551 & 1551 \\
\hline R2 Adj. & 0.377 & 0.378 & 0.182 & 0.184 & 0.369 & 0.371 \\
\hline Ref. month & Jan.2020 & $\leq$ Jan.2020 & Jan.2020 & $\leq$ Jan.2020 & Jan.2020 & $\leq$ Jan.2020 \\
\hline
\end{tabular}

Notes: Columns (1), (3), and (5) present WLS estimates shown in the right-hand side of Figure 3. Columns (2), (4), and (6) present WLS estimates based on the model (3), weighted by prefecture population size, and eight covariates are additionally controlled for. The treatment variable is the COVID-19-induced employment shock, which is calculated as equation (1). Robust standard errors are clustered at the prefecture level. 
Table C.3: Estimation results for unemployment benefits

\begin{tabular}{|c|c|c|c|c|c|c|}
\hline & \multicolumn{2}{|c|}{ Total } & \multicolumn{2}{|c|}{ Female } & \multicolumn{2}{|c|}{ Male } \\
\hline & (1) & $(2)$ & (3) & (4) & $(5)$ & (6) \\
\hline \multirow[t]{2}{*}{ Feb. 2020} & -3.719 & 1544 & -3.191 & 2.238 & -4.260 & 0.747 \\
\hline & $(3.847)$ & $\left(4.9^{\prime}\right.$ & $(4.072)$ & $(4.98$ & $(3.956)$ & $(5.8$ \\
\hline \multirow[t]{2}{*}{ Mar. 2020} & 0.230 & 5.630 & 0.495 & 6.006 & 0.005 & 5.209 \\
\hline & $(5.526)$ & $(6.948)$ & $(5.572)$ & $(7.062)$ & $(6.193)$ & (7.947) \\
\hline \multirow[t]{2}{*}{ Apr. 2020} & 4.335 & 9.873 & 5.495 & 11.089 & 3.232 & 8.632 \\
\hline & $(6.428)$ & $(8.287)$ & $(6.668)$ & $(9.090)$ & $(7.446)$ & $(9.132)$ \\
\hline \multirow[t]{2}{*}{ May. 2020} & 1.688 & 7.364 & 5.251 & 10.927 & -1.905 & 3.691 \\
\hline & $(8.533)$ & $(9.87$ & $(7.316)$ & $(9.77$ & $(11.813)$ & $(12.740)$ \\
\hline \multirow[t]{2}{*}{ Jun. 2020} & 8.374 & 14.187 & 10.170 & 15.928 & 6.650 & 12.442 \\
\hline & $(12.297)$ & $(14.172)$ & $(12.491)$ & $(15.030)$ & $(14.739)$ & $(16.067)$ \\
\hline \multirow[t]{2}{*}{ Jul. 2020} & 11.007 & 16.959 & 16.939 & 22.779 & 4.952 & 10.940 \\
\hline & (11.834) & (14.c & & (15.887) & & $(14.659)$ \\
\hline \multirow[t]{2}{*}{ Aug. 2020} & 5.319 & 11.409 & 11.282 & 17.205 & -0.780 & 5.405 \\
\hline & $(14.496)$ & $(15.255)$ & $(15.032)$ & $(16.629)$ & $(16.743)$ & $(16.937)$ \\
\hline \multirow[t]{2}{*}{ Sep. 2020} & 9.438 & 15.665 & 17.222 & 23.227 & 1.384 & 7.764 \\
\hline & $(15.094)$ & (14.958) & $(14.673)$ & $(15.261)$ & $(17.404)$ & $(17.096)$ \\
\hline Sample size & 1551 & 1551 & 1551 & 1551 & 1551 & 1551 \\
\hline R2 Adj. & 0.862 & 0.863 & 0.815 & 0.815 & 0.879 & 0.880 \\
\hline Ref. month & Jan.2020 & $\leq$ Jan.2020 & Jan.2020 & $\leq \operatorname{Jan} .2020$ & Jan.2020 & $\leq$ Jan.2020 \\
\hline
\end{tabular}

Notes: Columns (1), (3), and (5) present baseline WLS estimates shown in the lefthand side of Figure 4. Columns (2), (4), and (6) present WLS estimates based on the model (3), weighted by prefecture population size. The treatment variable is the COVID-19-induced employment shock, which is calculated as equation (1). Robust standard errors are clustered at the prefecture level. 
Table C.4: Estimation results for unemployment benefits, with covariates

\begin{tabular}{|c|c|c|c|c|c|c|}
\hline & \multicolumn{2}{|c|}{ Total } & \multicolumn{2}{|c|}{ Female } & \multicolumn{2}{|c|}{ Male } \\
\hline & (1) & $(2)$ & (3) & $(4)$ & $(5)$ & (6) \\
\hline \multirow[t]{2}{*}{ Feb. 2020} & 12.950 & 18.199 & 15.750 & 21.167 & 9.963 & 14.955 \\
\hline & & (10.1 & $(8.29$ & $(9.3$ & $(9.593)$ & $(11.7$ \\
\hline \multirow[t]{2}{*}{ Mar. 2020} & 21.687 & 27.0 & 24.565 & 30.065 & 18.745 & 23.933 \\
\hline & $(12.056)$ & $(13.816)$ & $(12.653)$ & $(13.953)$ & $(12.580)$ & $(14.809)$ \\
\hline \multirow[t]{2}{*}{ Apr. 2020} & 20.389 & 25.9 & 22.536 & 28.117 & 18.276 & 23.660 \\
\hline & $(14.082)$ & $(15.932)$ & $(14.864)$ & $(16.4$ & $(14.4$ & $(16.460)$ \\
\hline \multirow[t]{2}{*}{ May. 2020} & 33.084 & 38.7 & 37.184 & 42.8 & 28.816 & 34.3 \\
\hline & $(12.900)$ & $(14.40$ & $(12.692)$ & (14.1 & (15.118) & $(16.545)$ \\
\hline \multirow[t]{2}{*}{ Jun. 2020} & 24.256 & 30.055 & 24.375 & 30.120 & 24.155 & 29.930 \\
\hline & $(14.906)$ & $(17.246)$ & $(17.225)$ & $(19.6$ & $(16.821)$ & $(18.416)$ \\
\hline \multirow[t]{2}{*}{ Jul. 2020} & 27.857 & 33.7 & 31.002 & 36.830 & 24.448 & 30.419 \\
\hline & & & & & & \\
\hline \multirow[t]{2}{*}{ Aug. 2020} & 19.338 & 25.412 & 15.263 & 21.173 & 23.505 & 29.672 \\
\hline & $(15.631)$ & $(15.849)$ & $(13.875)$ & $(14.845)$ & $(21.500)$ & $(21.206)$ \\
\hline \multirow[t]{2}{*}{ Sep. 2020} & 21.971 & 28.183 & 19.458 & 25.451 & 24.343 & 30.706 \\
\hline & $(15.685)$ & $(14.715)$ & $(13.172)$ & & $(21.389)$ & $(20.526)$ \\
\hline Sample size & & & & & 1551 & 1551 \\
\hline R2 Adj. & 0.887 & 0.887 & 0.851 & 0.851 & 0.895 & 0.896 \\
\hline Ref. month & Jan.2020 & $\leq$ Jan. 2020 & Jan.2020 & $\leq \operatorname{Jan} .2020$ & Jan.2020 & $\leq$ Jan.2020 \\
\hline
\end{tabular}

Notes: Columns (1), (3), and (5) present WLS estimates shown in the right-hand side of Figure 4. Columns (2), (4), and (6) present WLS estimates based on the model (3), weighted by prefecture population size, and eight covariates are additionally controlled for. The treatment variable is the COVID-19-induced employment shock, which is calculated as equation (1). Robust standard errors are clustered at the prefecture level. 
Table C.5: Estimation results for second-tier safety net

\begin{tabular}{|c|c|c|c|c|c|c|}
\hline & \multicolumn{2}{|c|}{ Emergency S.A. } & \multicolumn{2}{|c|}{ General Support } & \multicolumn{2}{|c|}{ Housing Security } \\
\hline & (1) & $(2)$ & $(3)$ & $(4)$ & $(5)$ & (6) \\
\hline Apr. 2020 & $\begin{array}{c}18.723 \\
(21.950)\end{array}$ & $\begin{array}{c}18.693 \\
(21.755)\end{array}$ & $\begin{array}{l}-0.395 \\
(1.539)\end{array}$ & $\begin{array}{l}-0.410 \\
(1.522)\end{array}$ & $\begin{array}{c}1.103 \\
(0.730)\end{array}$ & $\begin{array}{c}1.028 \\
(0.711)\end{array}$ \\
\hline May. 2020 & $\begin{array}{c}73.840 \\
(42.803)\end{array}$ & $\begin{array}{c}73.809 \\
(42.459)\end{array}$ & $\begin{array}{c}9.879 \\
(12.245)\end{array}$ & $\begin{array}{c}9.863 \\
(12.136)\end{array}$ & $\begin{array}{l}15.311 \\
(6.970)\end{array}$ & $\begin{array}{l}15.236 \\
(6.932)\end{array}$ \\
\hline Jun. 2020 & $\begin{array}{c}88.768 \\
(32.722)\end{array}$ & $\begin{array}{c}88.737 \\
(32.461)\end{array}$ & $\begin{array}{c}54.387 \\
(29.934)\end{array}$ & $\begin{array}{c}54.371 \\
(29.696)\end{array}$ & $\begin{array}{l}27.584 \\
(9.358)\end{array}$ & $\begin{array}{l}27.509 \\
(9.317)\end{array}$ \\
\hline Jul. 2020 & $\begin{array}{c}34.689 \\
(21.224)\end{array}$ & $\begin{array}{c}34.658 \\
(21.043)\end{array}$ & $\begin{array}{c}82.444 \\
(31.787)\end{array}$ & $\begin{array}{c}82.429 \\
(31.538)\end{array}$ & $\begin{array}{l}15.334 \\
(5.316)\end{array}$ & $\begin{array}{l}15.259 \\
(5.281)\end{array}$ \\
\hline Aug. 2020 & $\begin{array}{c}27.162 \\
(14.477)\end{array}$ & $\begin{array}{c}27.131 \\
(14.347)\end{array}$ & $\begin{array}{c}52.064 \\
(16.912)\end{array}$ & $\begin{array}{c}52.048 \\
(16.772)\end{array}$ & $\begin{array}{c}6.615 \\
(2.999)\end{array}$ & $\begin{array}{c}6.540 \\
(2.972)\end{array}$ \\
\hline Sep. 2020 & $\begin{array}{c}21.875 \\
(15.342)\end{array}$ & $\begin{array}{c}21.844 \\
(15.209)\end{array}$ & $\begin{array}{c}43.071 \\
(23.620)\end{array}$ & $\begin{array}{c}43.055 \\
(23.427)\end{array}$ & $\begin{array}{c}4.442 \\
(2.152)\end{array}$ & $\begin{array}{c}4.367 \\
(2.124)\end{array}$ \\
\hline Sample size & 893 & 893 & 893 & 893 & 423 & 423 \\
\hline R2 Adj. & 0.795 & 0.798 & 0.722 & 0.726 & 0.749 & 0.750 \\
\hline Ref. month & Jan.2020 & $\leq$ Jan.2020 & Jan.2020 & $\leq$ Jan. 2020 & Jan.2020 & $\leq$ Jan. 2020 \\
\hline
\end{tabular}

Notes: Columns (1), (3), and (5) present baseline WLS estimates shown in the lefthand side of Figure 5. Columns (2), (4), and (6) present WLS estimates based on the model (3), weighted by prefecture population size, but individual linear trends are not incorporated. The treatment variable is the COVID-19-induced employment shock, which is calculated as equation (1). Robust standard errors are clustered at the prefecture level. 
Table C.6: Estimation results for second-tier safety net, with covariates

\begin{tabular}{|c|c|c|c|c|c|c|}
\hline & \multicolumn{2}{|c|}{ Emergency S.A. } & \multicolumn{2}{|c|}{ General Support } & \multicolumn{2}{|c|}{ Housing Security } \\
\hline & (1) & $(2)$ & $(3)$ & (4) & $(5)$ & (6) \\
\hline Apr. 2020 & $\begin{array}{c}4.941 \\
(27.175)\end{array}$ & $\begin{array}{c}4.930 \\
(26.958)\end{array}$ & $\begin{array}{c}0.002 \\
(3.346)\end{array}$ & $\begin{array}{c}0.008 \\
(3.318)\end{array}$ & $\begin{array}{l}-1.072 \\
(0.807)\end{array}$ & $\begin{array}{l}-1.147 \\
(0.804)\end{array}$ \\
\hline May. 2020 & $\begin{array}{c}60.029 \\
(50.569)\end{array}$ & $\begin{array}{c}60.018 \\
(50.170)\end{array}$ & $\begin{array}{c}9.231 \\
(18.599)\end{array}$ & $\begin{array}{c}9.237 \\
(18.451)\end{array}$ & $\begin{array}{l}-5.270 \\
(3.709)\end{array}$ & $\begin{array}{l}-5.345 \\
(3.697)\end{array}$ \\
\hline Jun. 2020 & $\begin{array}{c}49.230 \\
(52.096)\end{array}$ & $\begin{array}{c}49.219 \\
(51.683)\end{array}$ & $\begin{array}{c}62.337 \\
(34.330)\end{array}$ & $\begin{array}{c}62.343 \\
(34.059)\end{array}$ & $\begin{array}{l}-4.337 \\
(2.750)\end{array}$ & $\begin{array}{l}-4.412 \\
(2.745)\end{array}$ \\
\hline Jul. 2020 & $\begin{array}{c}13.609 \\
(28.076)\end{array}$ & $\begin{array}{c}13.598 \\
(27.849)\end{array}$ & $\begin{array}{c}87.776 \\
(39.148)\end{array}$ & $\begin{array}{c}87.782 \\
(38.840)\end{array}$ & $\begin{array}{l}-1.145 \\
(2.236)\end{array}$ & $\begin{array}{l}-1.220 \\
(2.225)\end{array}$ \\
\hline Aug. 2020 & $\begin{array}{c}20.326 \\
(20.236)\end{array}$ & $\begin{array}{c}20.315 \\
(20.073)\end{array}$ & $\begin{array}{c}35.863 \\
(20.370)\end{array}$ & $\begin{array}{c}35.869 \\
(20.207)\end{array}$ & $\begin{array}{l}-1.958 \\
(0.986)\end{array}$ & $\begin{array}{l}-2.033 \\
(0.985)\end{array}$ \\
\hline Sep. 2020 & $\begin{array}{c}36.598 \\
(24.363)\end{array}$ & $\begin{array}{c}36.587 \\
(24.173)\end{array}$ & $\begin{array}{c}26.989 \\
(20.992)\end{array}$ & $\begin{array}{c}26.995 \\
(20.825)\end{array}$ & $\begin{array}{l}-1.155 \\
(0.682)\end{array}$ & $\begin{array}{c}-1.230 \\
(0.676)\end{array}$ \\
\hline Sample size & 893 & 893 & 893 & 893 & 423 & 423 \\
\hline R2 Adj. & 0.870 & 0.872 & 0.852 & 0.855 & 0.963 & 0.963 \\
\hline Ref. month & Jan.2020 & $\leq$ Jan. 2020 & Jan.2020 & $\leq$ Jan. 2020 & Jan.2020 & $\leq$ Jan.2020 \\
\hline
\end{tabular}

Notes: Columns (1), (3), and (5) present WLS estimates shown in the right-hand side of Figure 5. Columns (2), (4), and (6) present WLS estimates based on the model (3), weighted by prefecture population size, but individual linear trends are not incorporated and eight covariates are additionally controlled for. The treatment variable is the COVID-19-induced employment shock, which is calculated as equation (1). Robust standard errors are clustered at the prefecture level. 
Table C.7: Estimation results for Public Assistance

\begin{tabular}{|c|c|c|c|c|}
\hline & \multicolumn{2}{|c|}{ Recipients } & \multicolumn{2}{|c|}{ Recipient Households } \\
\hline & (1) & $(2)$ & $(3)$ & (4) \\
\hline Feb. 2020 & $\begin{array}{c}2.108 \\
(0.835)\end{array}$ & $\begin{array}{c}2.613 \\
(1.513)\end{array}$ & $\begin{array}{c}1.259 \\
(0.620)\end{array}$ & $\begin{array}{c}2.617 \\
(1.170)\end{array}$ \\
\hline Mar. 2020 & $\begin{array}{c}4.612 \\
(1.393)\end{array}$ & $\begin{array}{c}5.137 \\
(1.970)\end{array}$ & $\begin{array}{c}3.171 \\
(1.094)\end{array}$ & $\begin{array}{c}4.578 \\
(1.617)\end{array}$ \\
\hline Apr. 2020 & $\begin{array}{c}6.788 \\
(2.041)\end{array}$ & $\begin{array}{c}7.333 \\
(2.665)\end{array}$ & $\begin{array}{c}5.491 \\
(1.297)\end{array}$ & $\begin{array}{c}6.949 \\
(1.932)\end{array}$ \\
\hline May. 2020 & $\begin{array}{c}9.448 \\
(2.273)\end{array}$ & $\begin{array}{l}10.014 \\
(2.913)\end{array}$ & $\begin{array}{c}7.482 \\
(1.811)\end{array}$ & $\begin{array}{c}8.989 \\
(2.406)\end{array}$ \\
\hline Jun. 2020 & $\begin{array}{l}13.654 \\
(3.194)\end{array}$ & $\begin{array}{l}14.241 \\
(3.869)\end{array}$ & $\begin{array}{l}10.349 \\
(2.437)\end{array}$ & $\begin{array}{l}11.906 \\
(3.068)\end{array}$ \\
\hline Jul. 2020 & $\begin{array}{l}13.694 \\
(3.750)\end{array}$ & $\begin{array}{l}14.301 \\
(4.369)\end{array}$ & $\begin{array}{c}9.978 \\
(2.789)\end{array}$ & $\begin{array}{l}11.585 \\
(3.400)\end{array}$ \\
\hline Aug. 2020 & $\begin{array}{l}14.134 \\
(4.153)\end{array}$ & $\begin{array}{l}14.761 \\
(4.760)\end{array}$ & $\begin{array}{l}10.376 \\
(2.902)\end{array}$ & $\begin{array}{l}12.034 \\
(3.511)\end{array}$ \\
\hline Sep. 2020 & $\begin{array}{l}15.521 \\
(4.700)\end{array}$ & $\begin{array}{l}16.169 \\
(5.262)\end{array}$ & $\begin{array}{r}11.411 \\
(3.360) \\
\end{array}$ & $\begin{array}{l}13.119 \\
(3.920)\end{array}$ \\
\hline Sample size & 1551 & 1551 & 1551 & 1551 \\
\hline R2 Adj. & 0.957 & 0.958 & 0.930 & 0.930 \\
\hline Ref. month & Jan.2020 & $\leq$ Jan.2020 & Jan.2020 & $\leq$ Jan. 2020 \\
\hline
\end{tabular}

Notes: Columns (1) and (3) present baseline WLS estimates shown in the left-hand side of Figure 6. Columns (2) and (4) present WLS estimates based on the model (3), weighted by prefecture population size. The treatment variable is the COVID19-induced employment shock, which is calculated as equation (1). Robust standard errors are clustered at the prefecture level. 
medRxiv preprint doi: https://doi.org/10.1101/2020.11.16.20232850; this version posted November 24,2021 . The copyright holder for this preprint (which was not certified by peer review) is the author/funder, who has granted medRxiv a license to display the preprint in

Table C.8: Estimation results for Public Assistance, with covariates

\begin{tabular}{lccccc}
\hline & \multicolumn{2}{c}{ Recipients } & \multicolumn{2}{c}{ Recipient } & Households \\
\cline { 2 - 3 } \cline { 5 - 5 } & $(1)$ & $(2)$ & $(3)$ & $(4)$ \\
\hline Feb. 2020 & 0.651 & 1.156 & & 0.069 & 1.430 \\
& $(2.259)$ & $(2.596)$ & & $(2.078)$ & $(2.360)$ \\
Mar. 2020 & 2.787 & 3.312 & 0.998 & 2.409 \\
& $(2.787)$ & $(3.078)$ & $(2.403)$ & $(2.699)$ \\
Apr. 2020 & 4.756 & 5.302 & 1.625 & 3.086 \\
& $(4.151)$ & $(4.374)$ & & $(2.951)$ & $(3.212)$ \\
May. 2020 & 4.305 & 4.872 & & 1.626 & 3.137 \\
& $(4.469)$ & $(4.639)$ & & $(3.612)$ & $(3.843)$ \\
Jun. 2020 & 6.808 & 7.395 & 2.788 & 4.350 \\
& $(5.313)$ & $(5.526)$ & & $(4.145)$ & $(4.403)$ \\
Jul. 2020 & 9.076 & 9.683 & & 4.098 & 5.710 \\
& $(5.501)$ & $(5.718)$ & $(4.251)$ & $(4.517)$ \\
Aug. 2020 & 8.261 & 8.889 & 3.228 & 4.891 \\
Sep. 2020 & $(5.963)$ & $(6.118)$ & $(4.552)$ & $(4.799)$ \\
& 11.639 & 12.288 & 5.185 & 6.898 \\
& $(6.155)$ & $(6.300)$ & $(5.030)$ & $(5.283)$ \\
\hline Sample size & 1551 & 1551 & 1551 & 1551 \\
R2 Adj. & 0.968 & 0.968 & 0.947 & 0.948 \\
Ref. month & Jan.2020 & $\leq$ Jan.2020 & Jan.2020 & $\leq$ Jan.2020 \\
\hline
\end{tabular}

Notes: Columns (1) and (3) present WLS estimates shown in the right-hand side of Figure 6. Columns (2) and (4) present WLS estimates based on the model (3), weighted by prefecture population size, and eight covariates are additionally controlled for. The treatment variable is the COVID-19-induced employment shock, which is calculated as equation (1). Robust standard errors are clustered at the prefecture level. 
medRxiv preprint doi: https://doi.org/10.1101/2020.11.16.20232850; this version posted November 24, 2021. The copyright holder for this preprint (which was not certified by peer review) is the author/funder, who has granted medRxiv a license to display the preprint in

It is made available under a CC-BY-NC-ND 4.0 International license .

\section{An alternative treatment variable}

Figure D.1: DID estimates for suicides ("full-time" employment shock)

(a) Total

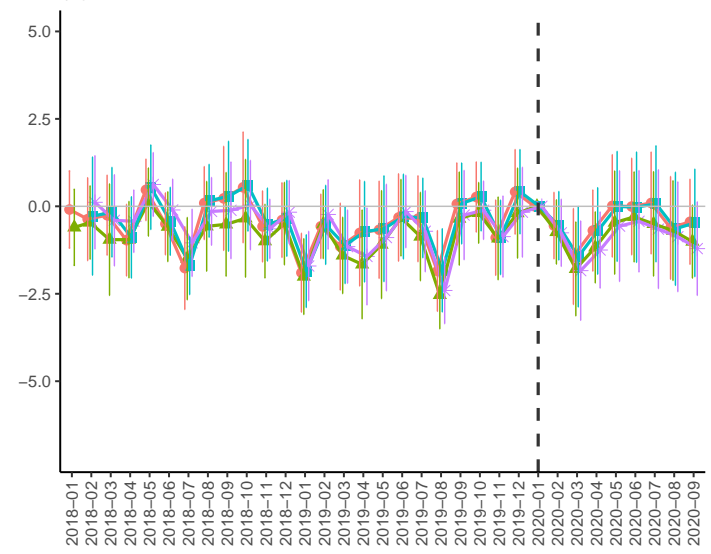

(c) Female

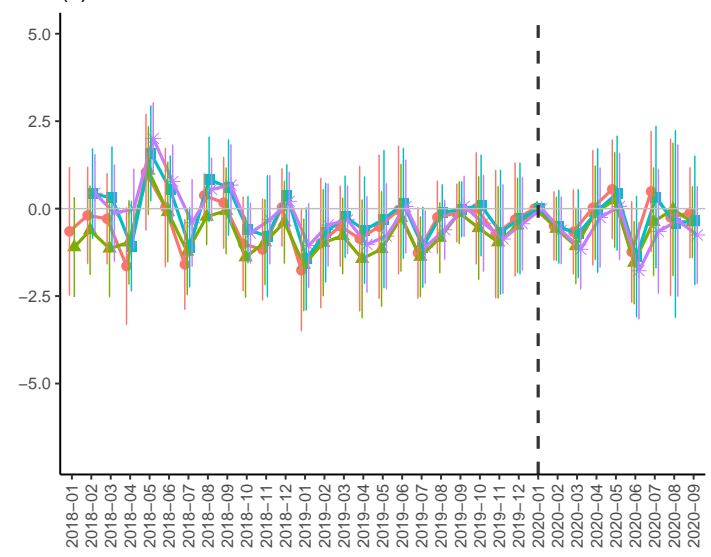

(e) Male

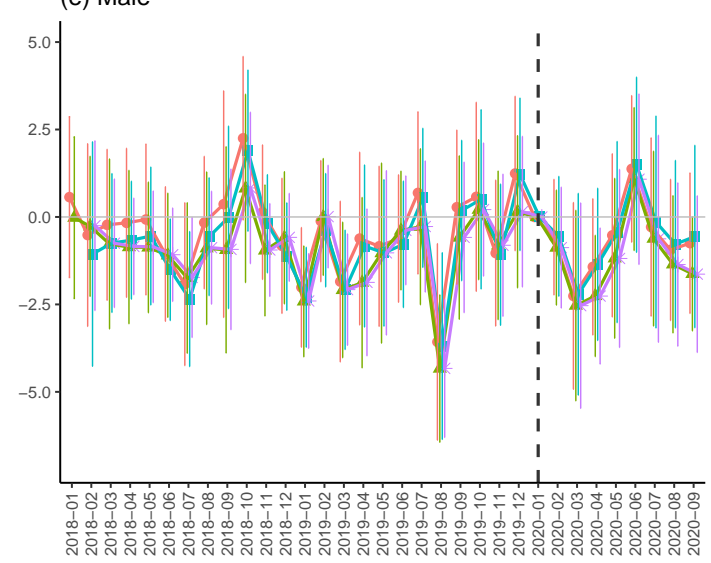

(b) Total, with covaraites

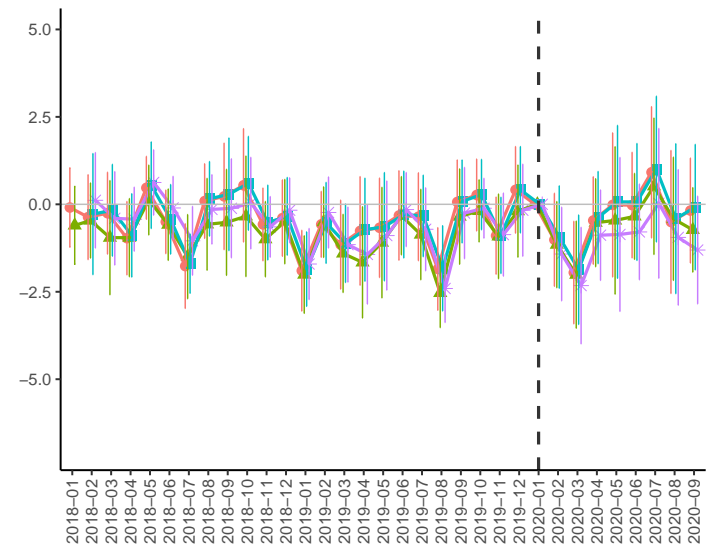

(d) Female, with covaraites

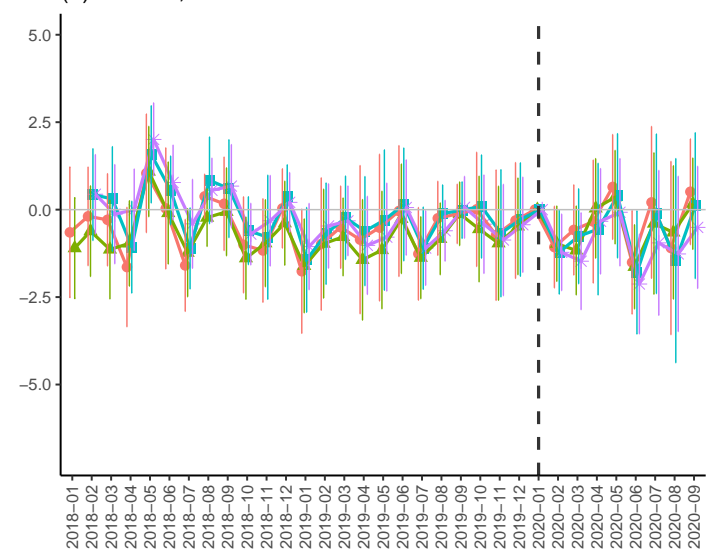

(f) Male, with covaraites

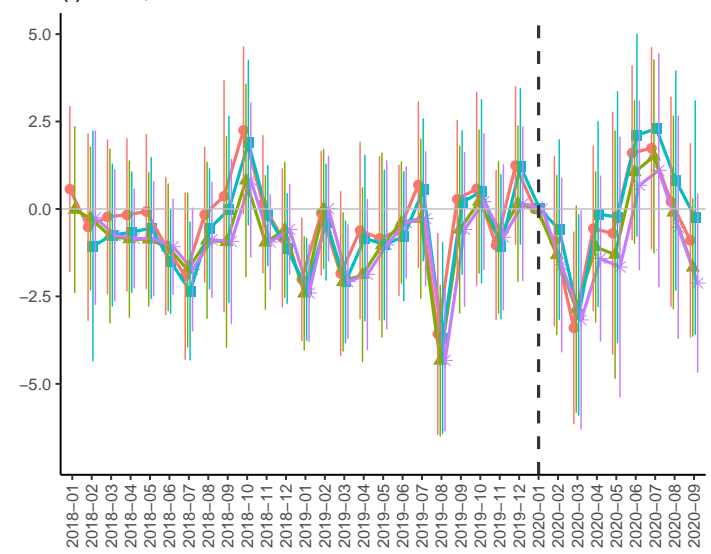

* OLS without trends $=$ WLS without trends $=$ OLS with trends $*$ WLS with trends

Notes: Notes: See the notes on Figure 3 for descriptions of plots and confidence intervals. WLS estimation is weighted by prefecture population size. Estimation "with trends" incorporates individual (i.e., prefecture) linear trends and estimation "without trends" does not include these linear trend terms. 
medRxiv preprint doi: https://doi.org/10.1101/2020.11.16.20232850; this version posted November 24, 2021. The copyright holder for this preprint (which was not certified by peer review) is the author/funder, who has granted medRxiv a license to display the preprint in

It is made available under a CC-BY-NC-ND 4.0 International license .

Figure D.2: DID estimates for unemployment benefit recipients ("full-time" employment shock)

(a) Total

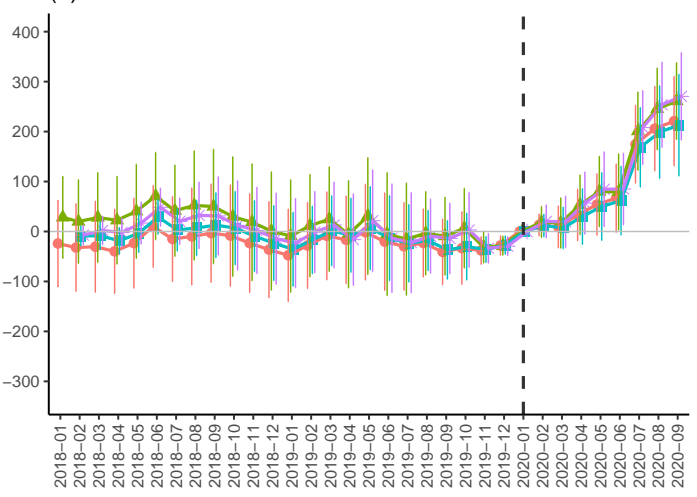

(c) Female

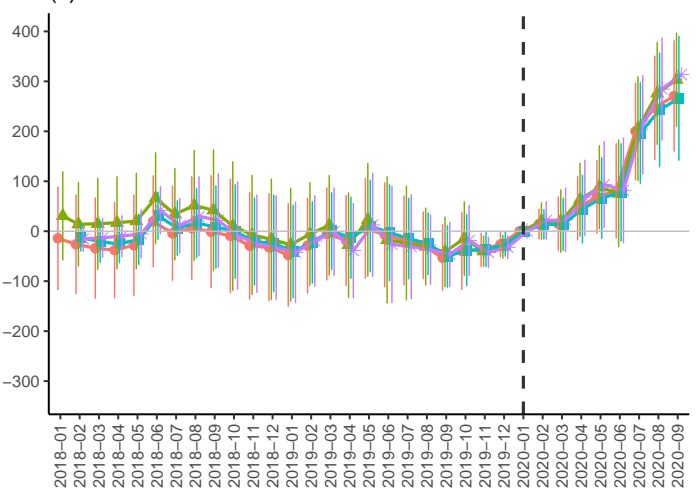

(e) Male

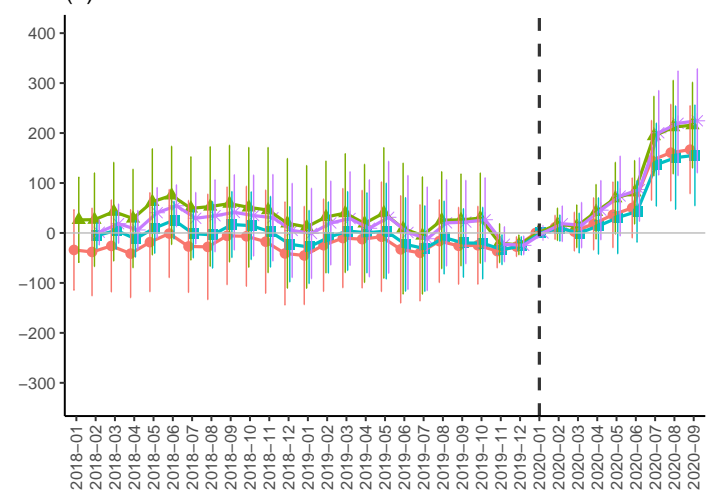

(b) Total, with covaraites

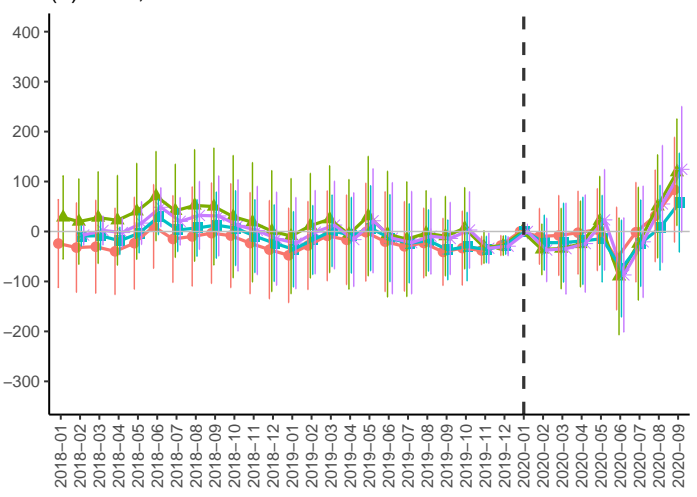

(d) Female, with covaraites

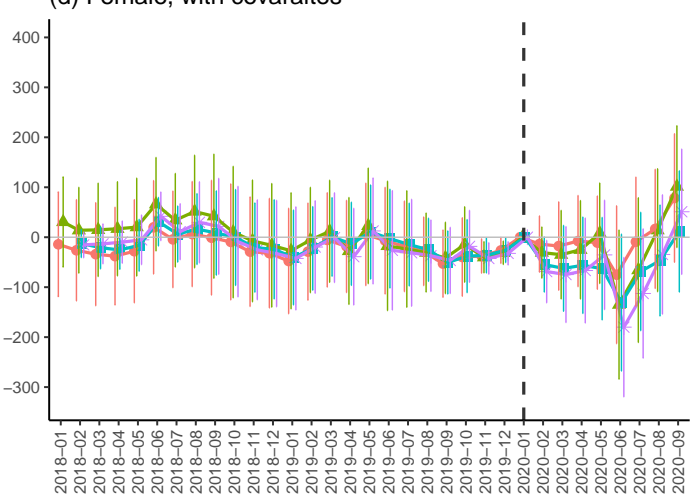

(f) Male, with covaraites

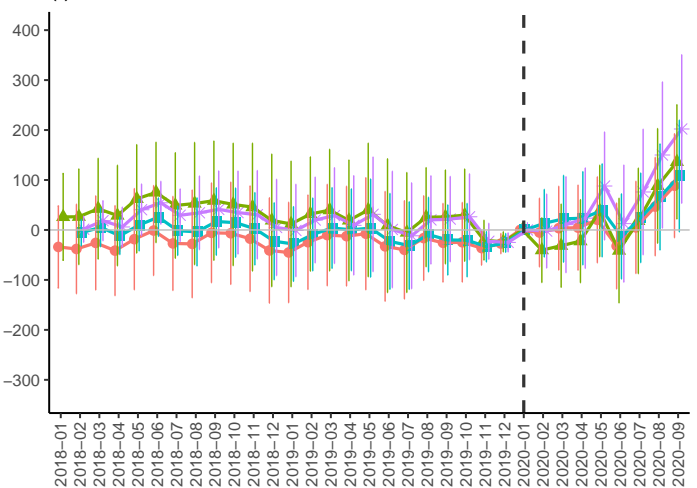

$*$ OLS without trends $\neq$ WLS without trends $*$ OLS with trends * WLS with trends

See the notes on Figure 4 for descriptions of plots and confidence intervals. WLS estimation is weighted by prefecture population size. Estimation "with trends" incorporates individual (i.e., prefecture) linear trends and estimation "without trends" does not include these linear trend terms. 
medRxiv preprint doi: https://doi.org/10.1101/2020.11.16.20232850; this version posted November 24, 2021. The copyright holder for this preprint (which was not certified by peer review) is the author/funder, who has granted medRxiv a license to display the preprint in

It is made available under a CC-BY-NC-ND 4.0 International license .

Figure D.3: DID estimates for second-tier safety net ("full-time" employment shock)

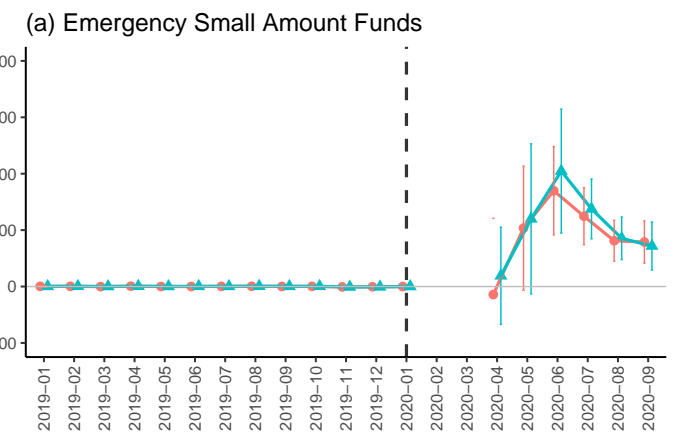

(b) Emergency Small Amount Funds, with covariates

(c) General Support Funds
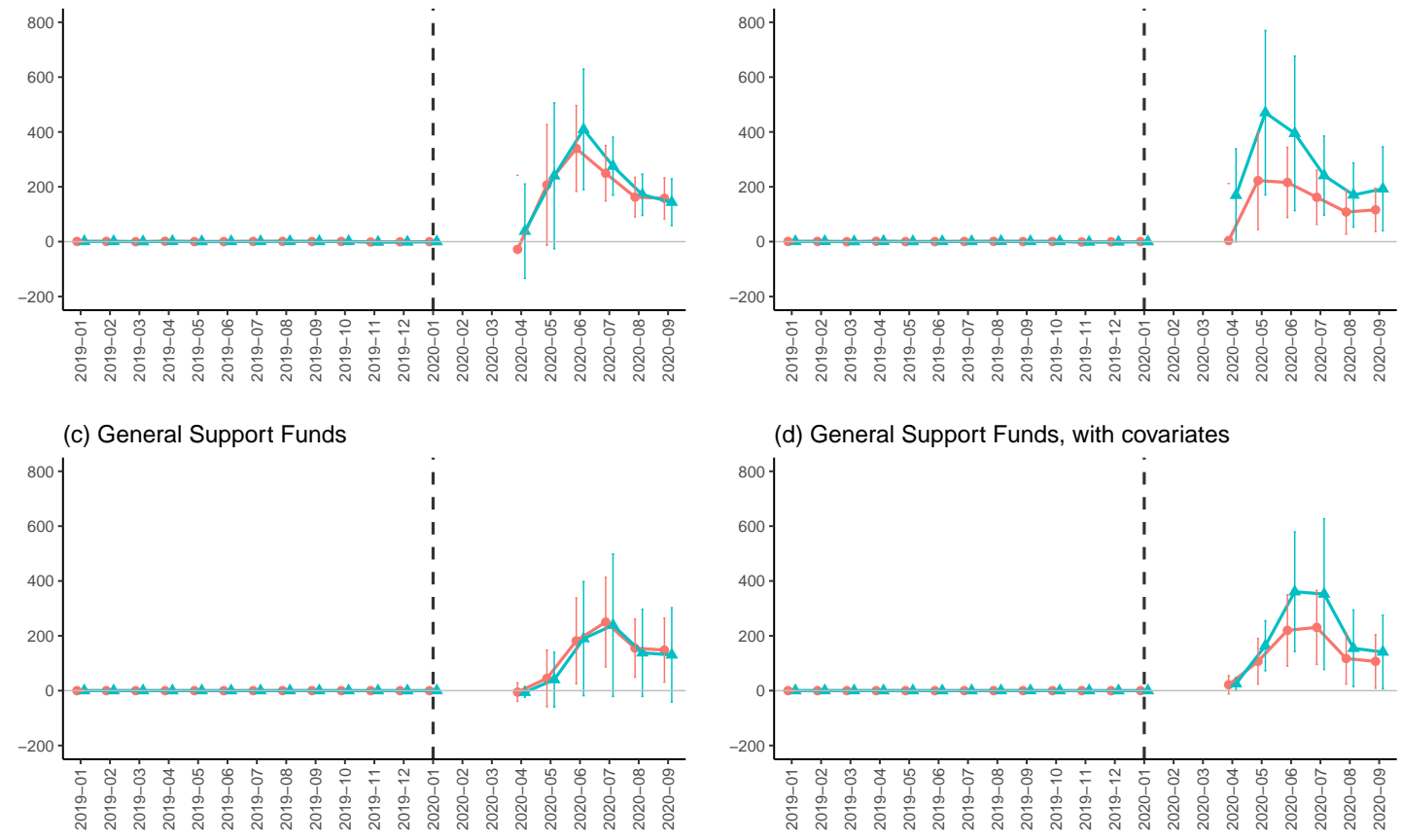

(d) General Support Funds, with covariates

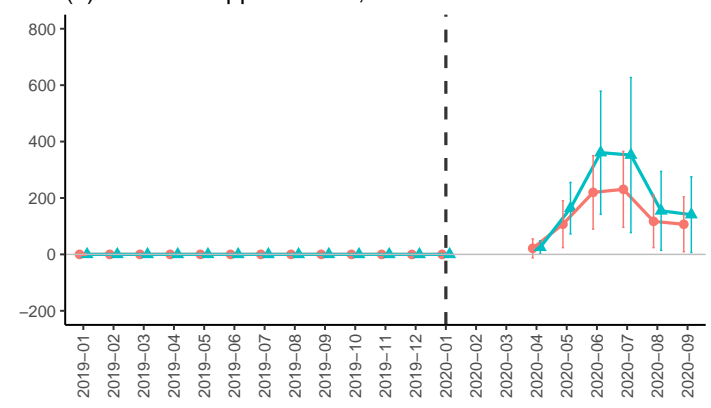

(e) Housing Security Benefit
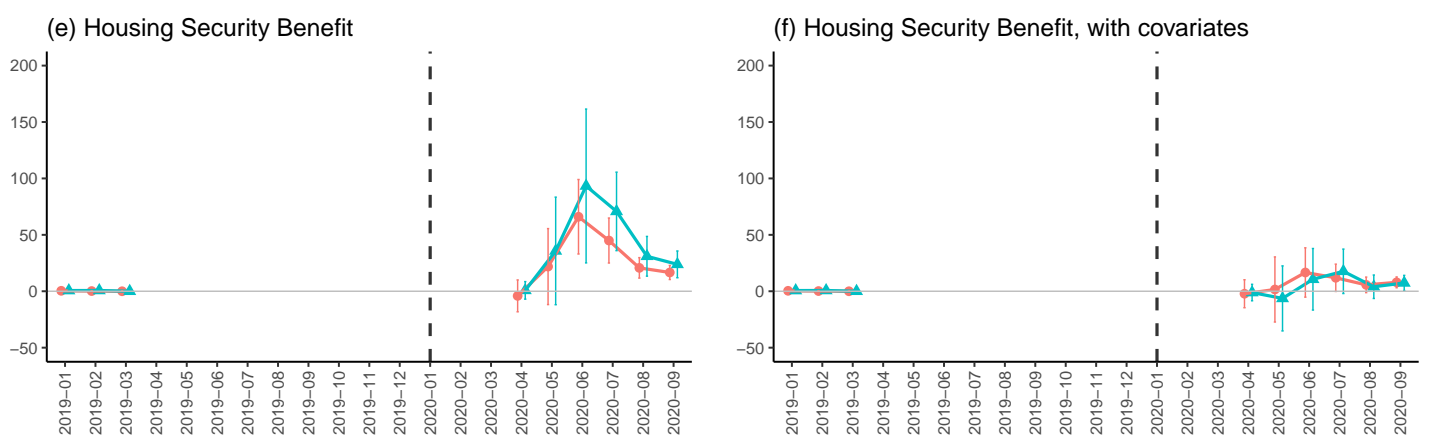

$\approx \mathrm{OLS}=\mathrm{WLS}$

See the notes on Figure 5 for descriptions of plots and confidence intervals. WLS estimation is weighted by prefecture population size. 
medRxiv preprint doi: https://doi.org/10.1101/2020.11.16.20232850; this version posted November 24, 2021. The copyright holder for this preprint (which was not certified by peer review) is the author/funder, who has granted medRxiv a license to display the preprint in

It is made available under a CC-BY-NC-ND 4.0 International license .

Figure D.4: DID estimates for public assistance ("full-time" employment shock)

(a) Recipients

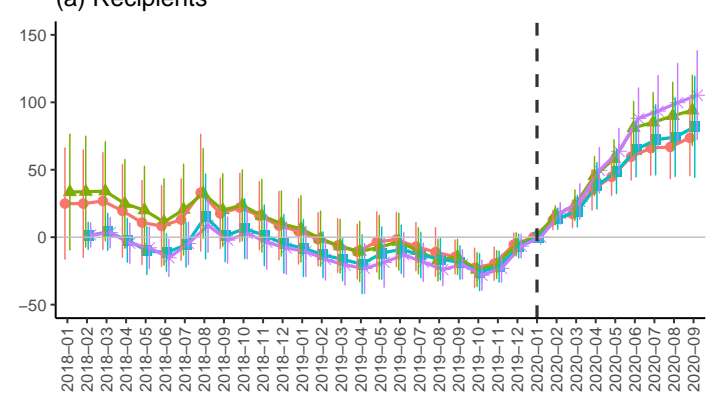

(c) Recipient households

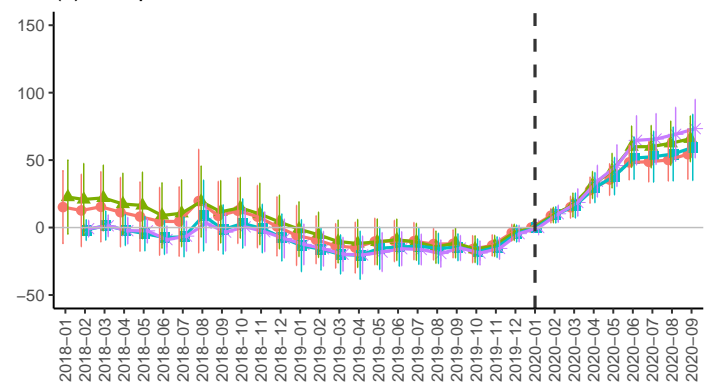

(b) Recipients, with covariates

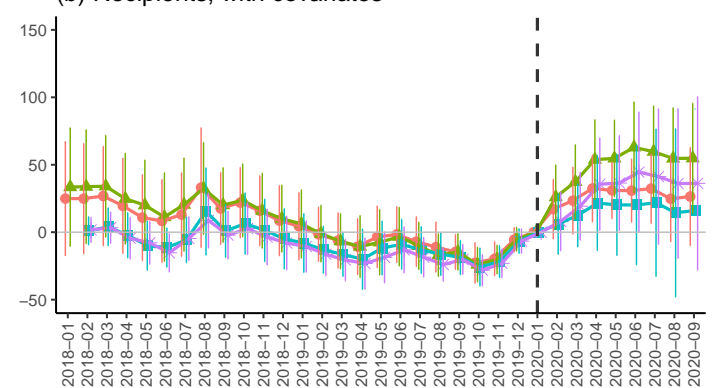

(d) Recipient households, with covariates

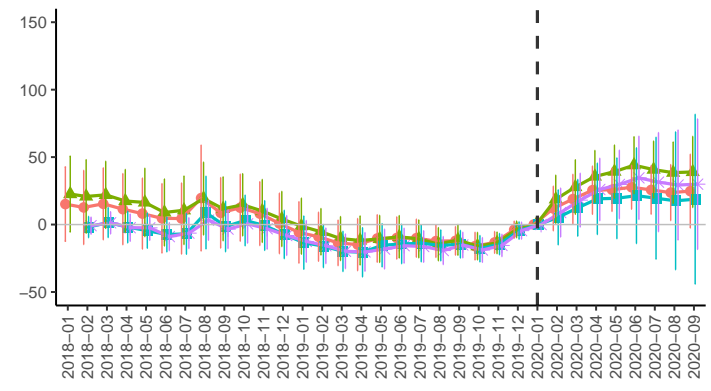

$*$ OLS without trends $\neq$ WLS without trends $=$ OLS with trends $*$ WLS with trends

Notes: See the notes on Figure 6 for descriptions of plots and confidence intervals. WLS estimation is weighted by prefecture population size. Estimation "with trends" incorporates individual (i.e., prefecture) linear trends and estimation "without trends" does not include these linear trend terms. Estimation using "WLS with trends" is identical to the baseline estimation in Figure 6. 
medRxiv preprint doi: https://doi.org/10.1101/2020.11.16.20232850; this version posted November 24, 2021. The copyright holder for this preprint (which was not certified by peer review) is the author/funder, who has granted medRxiv a license to display the preprint in

It is made available under a CC-BY-NC-ND 4.0 International license .

Figure D.5: Correlation between employment-shock variables

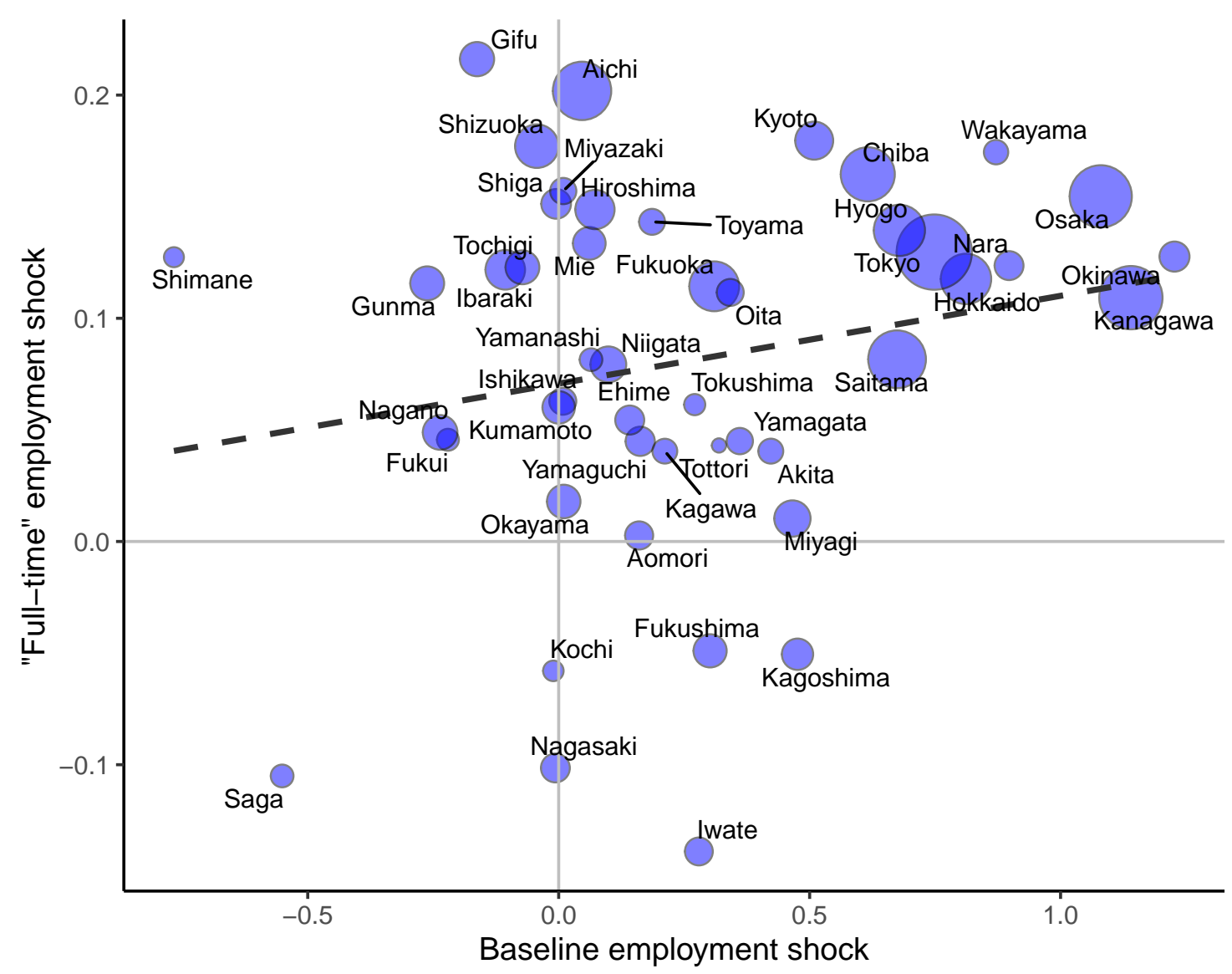

Notes: The sizes of each circle and prefecture name are based on the population size of each prefecture. The dashed line is the fitted linear regression line based on the ordinary least square (OLS) method. This graph shows that there is no clear correlation between the regional variations in the baseline employment shock and the alternative "full-time" employment shock. R squared is 0.04 and the estimated slope is not significantly different from zero at the $10 \%$ significance level. 